Maria Liliana Miranda da Costa

\title{
Processo de Criação e Percursos Metodológicos: Itinerários e Territórios da Companhia da Arte Andanças
}

Versão corrigida da dissertação apresentada à Escola de Comunicação e Artes da Universidade de São Paulo para obtenção do título de mestre em Artes Cênicas.

Área de Concentração:

Pedagogia Teatral

Orientadora: Profa. Dra. Maria Thaís Lima Santos

São Paulo 
Autorizo a reprodução e divulgação, total ou parcial deste trabalho, por qualquer meio convencional ou eletrônico, para fins de estudo e pesquisa desde que citada a fonte.

Ficha Catalográfica

Costa, Maria Liliana Miranda da.

Processo de criação e percursos metodológicos: itinerários e territórios da Companhia da Arte Andanças / Maria Liliana Miranda da Costa - São Paulo: M. L. da COSTA, 2012.

128p. : il. + 2 DVD

Dissertação (Mestrado) - Departamento de Artes Cênicas da Escola de Comunicação e Artes/ USP.

Orientadora: Maria Thaís Lima Santos

1. Pedagogia Teatral. 2. Dramaturgia. 3. Processo de criação. 4. Metodologia. 5. Composição. 6. Técnica. I. Santos, Maria Thaís Lima, orient. II. Título.

CDD 21.ed. -792 


\section{FOLHA DE APROVAÇÃO}

Maria Liliana Miranda da Costa

Processo de criação e percursos metodológicos: itinerários e territórios da Companhia da Arte Andanças.

Dissertação apresentada ao Departamento de Artes Cênicas da Escola de Comunicação e Artes da Universidade de São Paulo para obtenção do título de Mestre.

Área de Concentração: Pedagogia Teatral

Aprovado em:

\section{Banca Examinadora}

Profa. Dra. Maria Thaís Lima Santos (orientadora)

Instituição: ECA - USP

Assinatura:

Prof. Dr.

Instituição: Assinatura:

Prof. Dr.

Instituição: Assinatura: 
Esta pesquisa foi realizada com o apoio financeiro da Coordenação de Aperfeiçoamento de Pessoal de Nível Superior.

CAPES 
O que me move é a palavra. É aqui que encontro o norte ou a sua negação, mas sempre como afirmação de um devir. O que me mata é a palavra. Ela é a mulher que sou. Ela me regala e despedaça os espelhos. E me conforta e me ensina. Ela é o meu espírito, cifrado. (04.06.2011)

Para Thaís, Tó e Nirvana. 


\section{AGRADECIMENTOS}

Agradeço a Margarida Moreira Auto pela força, apoio, incentivo e cuidado desmedidos que recebemos, eu e minha filha, sempre que as dificuldades se apresentaram; a Andrea Bardawil Campos e a todos da Companhia da Arte Andanças, pela generosidade com que me acolheram e pela disponibilidade de tempo, de material e de vida; a João Miguel Moreira Auto, pela extensão dos meus braços e coração; aos amigos, alunos e mestres, pela inspiração, incentivo e compartilhamento; a minha família, por existir; a Angela Sousa pelo seu companheirismo e anteparo quando me faltaram forças; a Ann Stansel, Daniel Auto pelo auxílio linguístico; a Juliana Capibaribe e David Limaverde pelos apoios salutares e preciosos; a minha orientadora Prof ${ }^{\mathrm{a}}$. Dr ${ }^{\mathrm{a}}$. Maria Thaís, pela infinita paciência e pela eterna cordialidade. À CAPES, pelo privilégio da bolsa, cujo apoio fez toda a diferença. 


\section{RESUMO}

COSTA, Maria Liliana Miranda da. Processo de criação e percursos metodológicos: itinerários e territórios da Companhia da Arte Andanças. 2012. Dissertação (Mestrado) - Escola de Comunicação e Artes, Universidade de São Paulo, São Paulo, 2012.

O presente trabalho consiste no estudo histórico-descritivo (pesquisa teórica e de campo) sobre o trabalho da Companhia da Arte Andanças (Fortaleza-Ceará), apresentando algumas metodologias utilizadas em processos de aula e criação cênica, com o intuito de contribuir para a discussão e ressignificação de modos de fazer e conceber a práxis do ator-bailarino-performer. Proponho um olhar sobre o processo de criação do espetáculo O Tempo da Paixão ou o Desejo é um Lago Azul, livremente inspirado na obra do artista plástico cearense José Leonilson (1957-1993). Num primeiro momento descrevo o percurso e as atividades da Cia., bem como alguns de seus modos operacionais; na segunda parte exponho princípios e métodos de trabalho; no terceiro capítulo adentro no processo de montagem do supracitado espetáculo, pontuando aspectos de sua singularidade; e, por fim, teço uma breve reflexão sobre a relação entre técnica, criação e pessoalidade, cujos entrelaçamentos, suponho, tensionam uma composição dramatúrgico-afetiva.

Palavras-chave: pedagogia teatral - processos de criação - metodologia - técnica composição. 


\begin{abstract}
COSTA, Maria Liliana Miranda da. Process of creation and methodological trajetories: itineraries and territories of Companhia da Arte Andanças. 2012. Dissertation (Master) - Escola de Comunicação e Artes, Universidade de São Paulo, São Paulo, 2012.
\end{abstract}

This work consists of a historic-descriptive study, based on theoretical and field research, of the work of Companhia da Arte Andanças, in Fortaleza, Brazil, presenting some methodologies employed throughout processes in class of scenic creation in order to contribute to the discussion and the "resignification" of different ways of making and understanding the praxis of the actor/dancer/performer. I propose a new look at the creation process of the play "O Tempo da Paixão ou O Desejo é um Lago Azul", which was liberally inspired by the work of the visual artist, José Leonilson (1957-1993), from Ceará, Brazil. In the first part, I describe the trajectory and the activities of the company, along with some of its modes of operation. In the second part, I focus the discussion on the principles and methods of its work. In the third part, I immerse myself in the process of assemblage of the afore mentioned play, sampling aspects of its uniqueness. Finally, I present a brief reflection of the relation between technique, creation, and personality, whose connections are supposed to tense a dramaturgicalaffective composition.

Key-words: theatrical-pedagogic - processes of creation - methodology - technique composition 


\section{SUMÁRIO}

Introdução

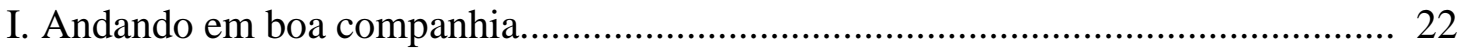

1.1 Percursos e contextos: da Escola ao Alpendre..................................................... 26

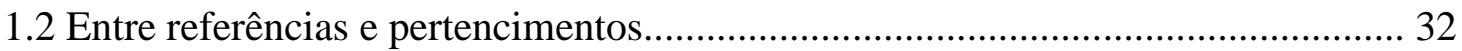

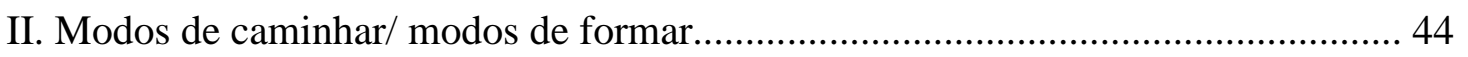

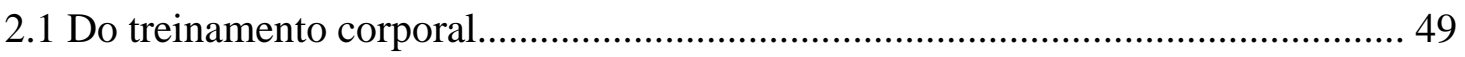

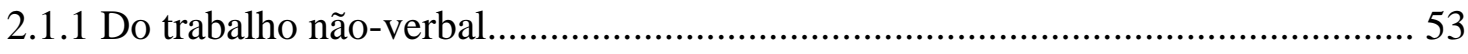

2.1.2 Desconstrução e consciência corporal................................................................ 57

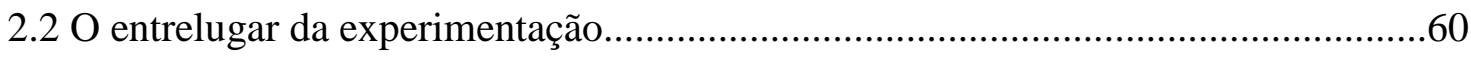

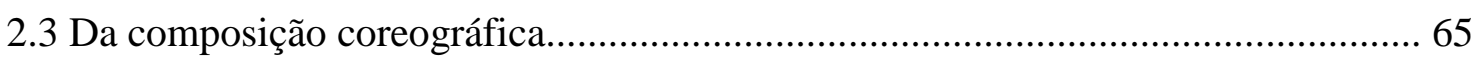

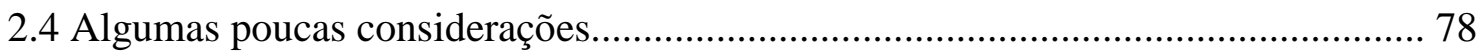

III. O Tempo da Paixão ou 'O Desejo é um Lago Azul' '................................................ 80

3.1 Do Processo criativo - conhecer em relação............................................................ 90

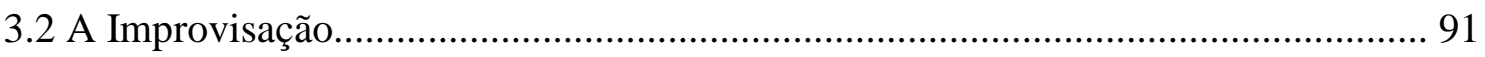

3.3 Blocos de sensação/ Pensando por imagens/ Dilatação do tempo............................ 95

3.4 Montagem/remontagem - refazendo itinerários sensoriais/ ressignificando estruturas

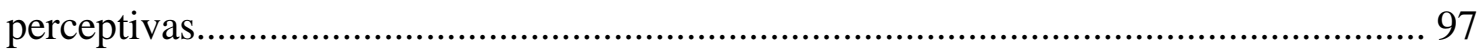


IV. Considerações iniciais: Técnica, criação e pessoalidade - vieses de uma composição dramatúrgico-pedagógica. .100

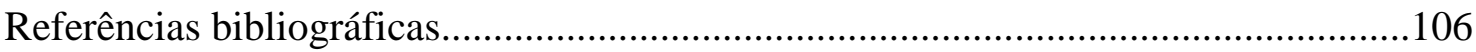

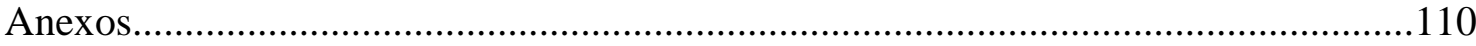

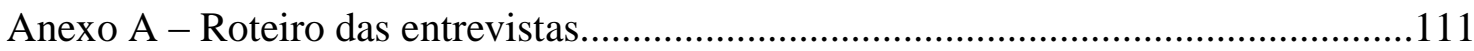

Anexo B - Fotos e textos dos espetáculos..................................................................112

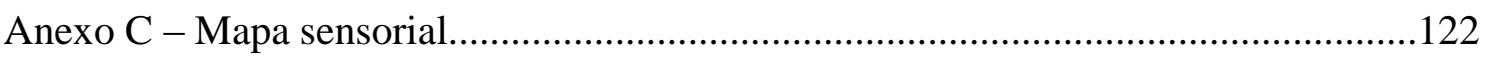

Anexo D - Registro audiovisual do espetáculo O Tempo da paixão ou 'O Desejo é um Lago Azul'.(DVD 1 - montagem de 2005; DVD 2 - remontagem de 2011) 


\section{INTRODUÇÃO}

Quando se configura algo e se o define, surgem novas alternativas. Essa visão nos permite entender que o processo de criar incorpora um princípio dialético. É um processo contínuo que se regenera por si mesmo e onde o ampliar e o delimitar representam aspectos concomitantes, aspectos que se encontram em oposição e tensa unificação. A cada etapa o delimitar participa do ampliar. Há um fechamento, uma absorção de circunstâncias anteriores, e, a partir do que anteriormente fora definido e delimitado, se dá uma nova abertura (OSTROWER, 1987, p. 26).

O itinerário da presente pesquisa manifesta-se sorrateiramente de forma oblíqua, mesmo tendo se mostrado, a princípio, como um percurso que paulatina e linearmente viria a se articular. Nesse seu redimensionar, o que parecia óbvio não mais se sustenta como tal, e nas agruras e bem-aventuranças que a escrita proporciona, vamos encontrando e perdendo, o rastro daquilo que nos movia.

O trabalho aqui apresentado consiste no estudo histórico-descritivo (pesquisa teórica e de campo) sobre o trabalho da Companhia da Arte Andanças ${ }^{1}$ (Fortaleza, Ceará), apresentando algumas metodologias utilizadas em processos de aula e criação cênica, com o intuito de contribuir para a discussão e ressignificação de modos de fazer e conceber a práxis do ator-bailarino-performer. Para tanto, algumas indagações se fizeram presentes: Como se (des)estrutura o pensamento no âmbito da criação artística, a partir do processo de imersão e de relações construídas em um percurso criativo? Por quais vetores de forças as metodologias são atravessadas, reconfiguradas, desviadas de

\footnotetext{
${ }^{1}$ A Companhia da Arte Andanças surgiu em abril de 1991, em Fortaleza, Ceará, sob a direção de Andréa Bardawil e Marília Bezerra, propondo-se, desde então, a desenvolver uma pesquisa de linguagem unindo dança e outras linguagens.
} 
um objetivo primeiro/último? Como se desdobra a autonomia do território ${ }^{2}$ criativo? O que existe na criação que pode vir a deslocar o olhar? Com essa pesquisa queremos empreender uma reflexão sobre o fazer artístico e pedagógico, entendendo-os como partes inseparáveis de uma mesma realidade e que têm diante de si um território de trânsitos, de informações, de conexões... para que se permita dizer, sentir, emanar.

A Companhia da Arte Andanças se apresenta como um grupo que, como poucos grupos e artistas independentes de Fortaleza, vem conseguindo manter-se desde o início da década de noventa. Seu trabalho, que envolve a pesquisa, a criação e o ensino, transita pelas linguagens do teatro, da dança, da performance e da videodança, seja pela criação de espetáculos, pela produção e participação em eventos de caráter artístico e cultural, seja pela atividade pedagógica e/ou outros projetos afins.

Pensando em referenciar-me com a própria literatura advinda ou estruturante da prática teórica da Cia., fui criando algo como um circuito fechado, um ambiente de reconhecimento mais do que de estranhamento. Feito o questionamento no trabalho de orientação, assenti que precisava 'abrir' o leque, ver outros aportes. Mesmo porque, ao falar do labor do grupo, inevitavelmente, os textos, os escritos, os autores, enfim, o que se agregou ao caminhar vai aparecendo, sendo revolvido. À proporção que o trabalho vai ganhando corpo, aquilo que se faz pertinente tende a ter seu lugar ao sol.

Na experiência acadêmica alguns escritos me estimularam, guiando e propondo articulações que se desdobram neste projeto como, por exemplo, as monografias $A$ dança e a palavra: a poesia de Adélia Prado como elemento de construção coreográfica no espetáculo Vagarezas e Súbitos Chegares e Vagarezas e Súbitos

\footnotetext{
${ }^{2}$ Segundo Guattarri e Rolnik, "os seres existentes se organizam segundo territórios que os delimitam e os articulam aos outros existentes e aos fluxos cósmicos. O território pode ser relativo tanto a um espaço vivido, quanto a um sistema percebido no seio do qual um sujeito se sente 'em casa'. O território é sinônimo de apropriação, de subjetivação fechada sobre si mesma. Ele é o conjunto dos projetos e das representações nos quais vai desembocar, pragmaticamente, toda uma série de comportamentos, de investimentos, nos tempos e nos espaços sociais, culturais, estético, cognitivos" (GUATTARRI, Félix \& ROLNIK, Suely. Micropolítica: cartografias do desejo. Apud COSTA, 1998, p. 66).
} 
Chegares: a Construção de uma Dramaturgia Corporal, trabalhos com os quais concluí as graduações em Letras e em Artes Cênicas.

O primeiro trabalho entrelaçava a literatura e dança, e também as artes plásticas. Propunha-se, como o título sugere, refletir sobre o lugar e o tratamento dado ao signo poético-escrito na cena, no gesto coreografado. A palavra como um texto que era apropriado antes e durante a cena. Uma coreografia inspirada em Adélia Prado ${ }^{3}$, em Elida Tessler $^{4}$ e transcriada nos corpos que se faziam carne e verbo.

A esse passo seguiu-se outro, que procurava entender as balizas da dramaturgia corporal no mesmo espetáculo. Como era o corpo na relação com a ação física, com suas partituras, com matrizes de movimento... o que se gerava e se projetava na feitura dessa dramaturgia.

A monografia de Angela Souza ${ }^{5}$ veio-me como uma forma de visitar um olhar conhecido sobre meu objeto. Compartilhamos alguns anos de trabalho no e a partir do Andanças. Dançamos, coreografamos, lecionamos, lemos, discordamos, enfim, experimentamos, com afinidades ou reveses, esse estar e o não mais estar na Cia. Também nos tocamos na medida em que nosso desejo de observar e rever nossos trabalhos sob o viés sociológico ou literário se fez presente via academia.

A dissertação de mestrado, agora livro ${ }^{6}$, de Rosa Primo, situou-me num campo de visibilidade articulado com outros fatores, grupos e contextos, que a sua laboriosa e percussora pesquisa rememorou sobre a dança cênica cearense.

\footnotetext{
${ }^{3}$ Escritora mineira que, em suas obras, deslinda o universo feminino. "Oráculos de Maio" foi uma de suas obras utilizadas no processo coreográfico de Vagarezas e Súbitos Chegares.

${ }^{4}$ Elida Tessler é artista plástica, professora em artes visuais e fundadora do Torreão (espaço de pesquisa em arte contemporânea). Assina a concepção visual do espetáculo da Cia. da Arte Andanças, Vagarezas $e$ Súbitos Chegares.

5 Andanças: um inventário etnográfico do processo de incorporação de uma "qualidade de ser do corpo”. (Monografia de graduação em Ciências Sociais/ Angela Souza/ 2006/ UFC).

${ }^{6}$ A dança possível: as ligações do corpo numa cena. Fortaleza: Expressão Gráfica Editora Ltda., 2006.
} 
A pesquisa sobre processos de criação de Cecília Salles é um importante referencial no que concerne à crítica genética e à crítica de processos. Do geral ao particular e vice-versa, a autora faz a análise de alguns percursos criativos de artistas em áreas as mais diversas, contribuindo para uma perspectiva transdisciplinar de procedimentos comuns em materialidades distintas, de singularidades em recorrências, enfim, do redimensionamento dos aspectos individuais e coletivos quando se fala em processo de criação de uma forma geral, ou quando se mergulha no universo particular de um artista.

As disciplinas cursadas na $\mathrm{ECA}^{7}$ trouxeram-me pontos de apoio, na medida em que questões pertinentes a processos criativos de grupos ou nossos próprios, foram focados ou tangenciados nas discussões sobre treinamento, atuação, processos colaborativos, performatividade etc.: um estudo comparativo e analítico de modos de fazer e entender a cena, sua preparação, sua potência sígnica e realização estética, como também algumas nuances de trabalho em grupo, da política do coletivo, da ética na criação.

Em 2011 tive a oportunidade de fazer duas oficinas que contemplaram algumas referências da Cia. da Arte Andanças: o workshop "O trabalho de ator no Teatro Laboratório", de 18 a 22 de outubro, das $18 \mathrm{~h} 30$ às $22 \mathrm{~h} 30$ - com Iaw Janowski (discípulo de Grotowski) - na sede do grupo Lume (Campinas- SP), e uma outra com Carlos Simioni (Lume), em Fortaleza/Ceará. Rever princípios de trabalho $^{8}$ foi importante na medida em que pude novamente considerar as metodologias reinventadas, reelaboradas. Também no final deste mesmo ano, ao iniciar a pesquisa de campo, pude

\footnotetext{
7 Seres Ficcionais: Identidade e Alteridade (Prof. Matteo Bonfitto); Encenação e Processos Compartilhados de Criação: da Criação Coletiva ao Processo Colaborativo (Prof. Antonio Araújo); Teatralidades Contemporâneas (Prof ${ }^{a}$. Silvia Fernandes).

${ }^{8}$ Os princípios de trabalho a que me refiro dizem respeito a busca de um trabalho de autenticidade, centrado no corpo, no seus incômodos, na sua energia potencial e seu treinamento, na via negativa, no trabalho sobre a presença.
} 
observar/ participar das aulas de dança ministradas por Andréa Bardawil e alguns outros membros do Andanças. Foi uma maneira de vislumbrar, experimentar e atualizar processos de trabalho, dialogando de forma mais aproximada com o objeto.

Os indicativos da banca do exame de qualificação reiteraram observações já feitas, e colocaram mais interrogações onde já tinha, ou seja, importante também era perceber que pistas ou pegadas estavam presentes no texto e no modo de fazê-lo, quais ausências e repetições, o que era discurso e o que era prática, o que era desejo e o que de fato acontecia. Atentar para a presença das vozes, para o lugar que eu me dava nesse percurso, de que forma aparecia a minha inquietação, o meu estar ali, a "Lili criadora". Que pensamentos e qual a força desses pensamentos na minha pesquisa. Do que se falou, do que se propôs, ou se contrapropôs, muito vai ficar por fazer, ainda que tenham reverberado as colocações pertinentemente feitas.

Firmou-se um grupo de estudos formado pelos orientandos da $\operatorname{Prof}^{\mathrm{a}}$. Dr ${ }^{\mathrm{a}}$. Maria Thaís, abarcando alunos da iniciação científica, mestrandos e doutorandos, a fim de pesquisarmos sobre "Tradição e Transmissão nas Poéticas Contemporâneas", que de forma bem ampla abarcava todas as pesquisas. Afinidades, dificuldades, perspectivas tornaram os encontros possíveis. Pensamentos, arte e vida compartilhados. Antes ou após as reuniões orientações individuais. Essa forma de fazer era um modo também de desanuviar as idéias que, apesar de distintas, se tocavam. De perceber o quão relevante é o olhar e a busca do outro. A possibilidade das conversas que iam das especificidades da pesquisa individual e coletiva ao que as atravessava, questões políticas, éticas... Era também um momento de se perguntar o porquê de se estar ali, não só em um grupo, ou nesta universidade, mas o porquê dessas pessoas e não outras... Era isso mesmo? Um tempo para duvidar, conhecer, revelar, entender, provocar. 
A minha experiência na Cia. da Arte Andanças - que me acompanha como um referencial de processo de trabalho e de poesia - está diretamente conectada à maneira como desenvolvo este trabalho. Ao falar de metodologias, de expectativas, de desapegos, de gentes, falo inevitavelmente das coisas que compartilhei, das coisas que encontrei e larguei, de coisas que nem toquei, ou se o fiz, não percebi. Exponho fragilidades e fortalezas, porque é assim que a arte opera, para nos percebermos maiores e menores do que somos, matizando e depurando a dor e a alegria. Para nos entendermos como obra inacabada.

Revisitando então dizeres, imagens, falas, discursos, revolvo minha memória que é partner da memória alheia, e que só assim significa, compõe. Material que se recompõem em entrevistas suavemente delineadas, mas com índices de percurso, para que, pontos importantes sejam contemplados. Cúmplice desses passos, observo e participo. Uma ação em via de mão dupla que reacende e estimula o desejo de falar, de procurar, de entender. Alguns convidados não puderam estar presentes, como gostaria, nas palavras tecidas, proferidas, mas pude revê-los e encontrá-los nas entrelinhas.

No primeiro capítulo refaço um caminho de deslocamentos e encontros. A partir da fragmentação e análise de um breve texto sobre o percurso e atividades da Cia., procuro entrelaçar e pontuar aspectos que percebo importantes para o entendimento/ contextualização das escolhas e interlocuções.

No segundo capítulo busco concentrar-me em identificar e analisar tópicos específicos que são ou foram trabalhados na Cia., em seus processos de pesquisa de linguagem/métodos, na construção de espetáculos, técnicas, poéticas e estratégias de/ na composição. 
No terceiro capítulo tenciono rastrear e identificar no processo de criação do espetáculo O Tempo da Paixão ou 'O Desejo é um Lago Azul', quais os aspectos/ peculiaridades que o constituem enquanto singularidade no modo como este se relaciona com os processos anteriores, bem como o traçado metodológico que a Companhia da Arte Andanças vem desenvolvendo, procurando relacionar as articulações que são/foram feitas com outros projetos, linguagens, materiais e conceitos.

Nas derradeiras páginas que dão corpo ao capítulo final retomo algumas questões reiteradas pela Cia., que são a Técnica, a Pessoalidade e a Criação. Qual o lugar de cada uma ou qual a relevância dessa tríplice relação para a criação/formação do performer, do intérprete-criador, naquilo que se configuraria como uma composição dramatúrgico-afetiva? Como o território criativo, que perfaz obra e caminho, diluindoos ou condensando-os, transita e faz atritar meios e fins, não só como estratégia adaptativa, mas como invenção de territórios impossíveis?

Busco entender a experiência na Cia. da Arte Andanças como algo que se constitui no grupo e para além dele, posto que situado em um ambiente artístico-cultural específico, entremeado por um desejo de busca e construção de uma linguagem, de um método, ou talvez, um modo de existir. Falar do Andanças é um trabalho de idas e voltas, de encontros e desencontros, do aqui-e-agora e do que já foi. É vasculhar-me, dar-me voz, rever e antever. É atrair e escutar outros sons, vozes, discursos e ver-me neles e na ausência deles. Jogo sem acertos, nem erros, jogo dos caminhos cruzados. 


\section{I - ANDANDO EM BOA COMPANHIA}

Em 1995 encontro Andréa Bardawil ${ }^{9}$, a Escola e a Companhia da Arte $\operatorname{Andanças~}^{10}$. A princípio fui fazer sapateado, mas ao conhecer o espaço em que a Companhia trabalhava, ensaiando e dando aulas, fiquei apaixonada pela proposta, que fugia ao padrão das academias de Fortaleza, e fui fazer tudo o que podia e que ali era ofertado: dança contemporânea, balé clássico, acrobacia, teatro, canto, alongamento. Uma fuga que era um enfrentamento. Sair de um ambiente de academia de dança para respirar e compartilhar, noutro espaço, com outras pessoas, um desejo de busca, um frescor de passos ainda não dados, mas cruciais.

Às voltas com seus limites e com seus sonhos, Andréa Bardawil ${ }^{11}$ se via permanentemente instável, atravessada pelas circunstâncias de imobilidade que, se a princípio eram indicativo de paralisia, por outro lado e, por sua forma de resistir e se redescobrir, faziam-na ir mais consciente e inteira na busca da realização de seus projetos, de suas utopias, de seu prazer:

Os problemas com meu joelho direito começaram por volta de meus 18 anos, quando já tinha idade e independência para escolher a dança como forma incondicional de vida (e não apenas como "meio"), e justo por isso os momentos de paralisia parecem ter adquirido maior peso. Ou seja: as circunstâncias começaram a me exigir uma nova sensibilidade em relação ao meu próprio corpo e seu movimento, sempre em busca de descobrir como me mover na imobilidade. Aos momentos de completa frustração, onde pensava não mais poder dançar, seguiam-se imediatamente outros, ricos em novas percepções,

\footnotetext{
${ }^{9}$ Coreógrafa, é diretora da Companhia de Arte Andanças desde 1991. Participou dos projetos Rumos Itaú Cultural Dança e recebeu a Bolsa Vitae de Artes em 2000. Foi Assistente Artística do Colégio de Dança do Ceará em 2003. Atualmente é coordenadora do Núcleo de Dança do ALPENDRE - Casa de Arte, Pesquisa e Produção, coordenadora pedagógica do Curso Técnico em Dança (Senac, Secult e Centro Cultural Dragão do Mar) e da Bienal Internacional de Dança do Ceará.

10 A companhia da Arte Andanças foi criada em 1991, constituída por um grupo de bailarinas profissionais que buscavam um trabalho para além das técnicas de dança (jazz, sapateado) que já conheciam. Para tanto, aproximaram-se da pesquisa corporal e do teatro. Em 1993 abriram um espaço/ sede da Companhia, a Escola da Arte Andanças, dirigida por Andréa Bardawil e Marília Bezerra, onde a Companhia dava aulas, promovia eventos e ensaiava.

${ }^{11}$ No decorrer do trabalho, refiro-me à Andrea Bardawil Campos, ora como Andréa, ora como Bardawil. Para os demais integrantes, uma vez apresentados e familiarizados, usarei o primeiro nome. Por vezes, fazendo menção à Companhia da Arte Andanças, utilizarei Cia. ou simplesmente Andanças.
} 
onde por sua vez me redescobria dançando, de qualquer forma e apesar de tudo. (Bardawil, textos para Xerox, 1999).

Muito cedo Bardawil se envolveu e se comprometeu com a dança e seu universo, e muita também era a intensidade em cada escolha, talvez por isso a intermitente pergunta: como? Daí questionar o estado de coisas, percebendo o já legitimado não como solução mas como problema:

Descobrir como continuar dançando com meus limites, me fez repensar profundamente a função da técnica para a dança, enquanto arte, até concluir e reafirmar sua importância, chegando à pergunta: que base técnica pode servir para a formação de um bailarino, além do balé clássico? ("Textos para Xerox", 1999)

A experiência na criação da Cia. Andanças... não bastavam mais as relações instituídas; alarga-se o desejo e cria-se a Escola, que era uma maneira de produzir encontros, dividir expectativas, pôr-se em risco, dar-se. Quem se aproximava sentia algo diferente, mesmo sem saber como nomear aquilo. Era essa a atmosfera que alimentava a vontade de andar em boa companhia.

Um outro ponto, desdobro desse investimento, é a preocupação pedagógica incutida no labor do cuidar do espaço, dos partícipes, dos modos de transmissão, de incorporação, enfim, olhar com mais atenção para a complexidade que é construir e dar a ver uma visão de mundo, de corpo e de dança. Transitar num heterogêneo de pessoas, de técnicas, de pensamentos, de percepções, exigia um trabalho permanente de escuta, para não cair num hermetismo, ou sentimentalismo ou na gratuidade do diverso. Investir-se de responsabilidades para consigo e com os outros, experimentar o câmbio de lugares e condições, desestabilizava as acomodações e intensificava os incômodos. Sâmia Bittencourt, integrante da Cia., falando de seu aprendizado enquanto criadora vai refletindo sobre fazeres que se interpenetram e se potencializam. Sobre a obrigação de 
dar aulas no Andanças, ela questiona tal condição fazendo perguntas à diretora Andréa Bardawil:

'Por quê que eu tinha que dar aula?' Eu não queria... eu morria de vergonha... 'Não basta chorar nas aulas, me expor tanto nas aulas, eu tenho que me expor dando aula também?' Pra mim era rasgar a carne, entendeu? Ao que ela respondeu: 'Você vai aprender a criar como? Como é que você vai encontrar os seus meios de mexer com o outro, de propor? Só se aprende dando aula'. Aí ela me encorajou. Depois eu vi, que de fato é, se eu não começar... não é "dar aula", mas se eu não começar a experimentar, a propor coisas pra eu ver no outro eu não saio do canto. ${ }^{12}$

Era praxe que nos revezássemos nos treinamentos e ensaios para a condução do aquecimento, e, por vezes, de toda a prática. Em alguns casos essa responsabilidade não era previamente acordada. Muitas vezes Andréa Bardawil indicava quem assumiria o trabalho já no momento de começar. Nem sempre tal designação era recebida de bom grado. Havia mesmo momentos em que a probabilidade de dar aula era proporcional a nossa indisposição e vontade de não fazê-lo. Na maioria dos casos, essa manobra fazia com que o estado de resistência se convertesse num estado redobrado de atenção e entrega.

O perfil do grupo e da pesquisa empreendida demandavam um jogo de perspectivas entre procedimentos e estudos de campos de saber diferentes, passeando por princípios, encontrando similitudes e contrapontos:

A idéia de trabalhar a partir da Antropologia Teatral surgiu da confluência de vários fatores, mas dois em particular: o fato de termos corpos muito diferentes na Companhia - que dificilmente são associados ao estereótipo de corpo de um bailarino; a vontade de pesquisar uma linguagem mais própria, livre - na medida do possível - de características que já começam a se configurar como padrões de dança contemporânea. Percebemos que Barba passa longe de tentar estabelecer um método, apesar de suas reflexões se fundamentarem num elaborado processo de pesquisa sistematizada. Antes disso, a identificação e a explicitação dos princípios que retornam sugerem um leque de possibilidades para a elaboração de um processo de pesquisa. Os princípios são os mesmos que aplicamos na dança. O trabalho a partir desses princípios nos exigiria, então, formular nossos próprios

\footnotetext{
${ }^{12}$ Entrevista concedida em 14 de novembro de 2011.
} 
problemas e escavar nossas próprias soluções" (Andrea Bardawil, relatório final do Tempo da Delicadeza $a^{13}, 2001$ )

Referências como pontos de partida, como alavancas que impulsionam. Conhecer para deixar fluir ainda mais a constância do desaprender, e do desaprender para o encontrar, e do encontrar para o refazer de itinerários. Assumindo os riscos de não caber no 'quadradismo dos versos', render-se à coragem de criar.

Em poucos meses fui convidada a participar da montagem de um musical Capitães da Areia ${ }^{14}$, que foi um processo com os alunos da escola e a companhia. Nesse trabalho os ensaios eram intensos e podia, até deveria mesmo, fazer as aulas que quisesse/pudesse, já sem arcar com nenhum pagamento de mensalidade ${ }^{15}$. Depois desse espetáculo a Andréa convidou-me para me achegar ao grupo Andanças (cia.) no qual participei como bailarina, atriz e professora, até 2002, quando se deu meu afastamento. Esse convite deixou-me muitíssimo feliz, porque tinha encontrado um lugar e uma forma de trabalhar diferentes das que eu já conhecia. Essa diferença se mostrava principalmente pelos desejos que ali se mesclavam, pela disponibilidade irrestrita dos integrantes, pelo caráter profissional que se buscava, pela preocupação com a formação, com o outro e com o que se entendia por pesquisa em arte.

Linguagem própria, método de trabalho, técnicas, pessoalidades, presença cênica, qualidade de movimento... um encontro com a dedicação, a exigência e a

\footnotetext{
${ }^{13}$ O espetáculo o Tempo da Delicadeza (2002), anterior ao Tempo da Paixão ou 'O Desejo é um Lago Azul', contou com suporte financeiro (Bolsa Vitae de Artes) para sua pesquisa e execução, tendo permitido um maior tempo de trabalho. No corpo de nossa escritura, por vezes, indicaremos os espetáculos supracitados de forma reduzida, a saber TD e TP, respectivamente.

${ }^{14}$ Espetáculo baseado no romance homônimo de Jorge Amado e apresentado em 1995, dentro da programação da Semana Jorge Amado, em Fortaleza, no Theatro José de Alencar.

${ }^{15}$ A Escola tinha uma grande abertura para os artistas ou estudantes que tivessem interesse nas linguagens ali desenvolvidas, por isso, era freqüente a admissão de alunos bolsistas, tanto que, em determinado momento, o número de bolsistas superava em muito o de alunos pagantes. A Escola, não tendo como manter-se, acabou fechando. A Cia. mudou de sede e passou a ensaiar e dar aulas no SEST/SENAT, e, posteriormente, no ALPENDRE, onde está até hoje. Quando da montagem do espetáculo Os Tempos, a Cia. realizou seus encontros e ensaios no Instituto Aquilae, período em que o grupo ausentoa-se do Alpendre, retornando logo depois, quando este passa a abrigar as atividades da Bienal Internacional de Dança do Ceará.
} 
generosidade. Uma atmosfera de descobertas, intensidades, proposituras e riscos. Uma identificação que não se dava só por afinidades, mas por justaposição de contrários, choque de alteridades. 'Vagarezas e súbitos chegares'.

\subsection{Percursos e contextos: da Escola ao Alpendre}

Desenvolver um trabalho artístico de forma independente requer muito mais do que a construção de obras. É preciso encontrar pares, lugares, espaços em que a estética possa ter abrigo, em que a poética possa contaminar aqueles que cruzam o mesmo caminho. E que se possa realmente ter condições de trabalho, e assim vão se dando as parcerias, as trocas.

A Companhia da Arte Andanças trilhou os mesmos passos de quase todos os grupos independentes do Ceará e do Brasil, na busca por alguma viabilidade de seu trabalho: iniciou em 1991 na sala de uma academia; a partir daí, investiu na sua pesquisa de linguagem, realizando um trabalho próprio e cada vez mais independente e itinerou por várias salas e espaços, permutando serviços, a fim de conseguir um espaço para ensaios; apostou pela primeira vez numa sede própria em 1994, ao abrir a Escola da Arte Andanças, que funcionou até 1996. A itinerância teve seu curso suspenso desde 1999, quando passa a sediar-se no Alpendre - Casa de Arte, Pesquisa e Produção, dividindo espaço, tempo e inquietações com outros artistas interessados na arte contemporânea, constituindo um novo espaço de encontro. Além das informações técnicas pertinentes à dança, especificamente, inicia-se um processo intenso de troca e produção com as Artes Plásticas, o Vídeo, a Literatura e a Fotografia. ${ }^{16}$

Quando se coloca a necessidade de viabilizar um trabalho provoca deslocamentos, assinalamos que, na verdade, esse deslocamento já se opera antes, dentro mesmo de uma prática, de um hábito ou de uma perspectiva já dados, nos quais vai se fomentando uma inquietação que pede, por assim dizer, um espaço diferenciado

\footnotetext{
16 Os textos citados no presente subcapítulo foram extraídos de: http://www.alpendre.org.br/Alpendre/NúcleodeDança-Andanças.htm, em 15 de fevereiro de 2011.
} 
para vicejar. Na circunscrição de uma academia de dança, com todos os seus apelos e hierarquias e enquadramentos e legitimações e ideais, gera-se, via de regra, um ambiente refratário à quebra de rotina, de paradigmas, posto que preza por uma estabilidade e uma previsibilidade no modo de ser conduzida, no modo como opera e produz suas ações. Não é do feitio acadêmico lidar de bom grado com o que lhe é, por vezes, contraditório. Muitas águas de um rio, mas todos os fluxos num mesmo sentido.

A Cia. busca, nesse não caber, uma outra dinâmica de existência, que contemplasse uma pesquisa de linguagem e não só uma repetição de cânones. Nas trocas para se conseguir um espaço de ensaio e de pesquisa, pousos breves em instâncias acolhedoras, mas que ainda não correspondiam aos reclames do que se gestava. Era preciso algo maior, e a aposta foi feita e um projeto concebido: Escola da Arte Andanças.

Ao falarmos de espaços ou lugares, reiteramos o fato de que a fisicalidade do lugar integra uma corporeidade, uma existência e significação distendidas. O ambiente emana, seduz, provoca. Presenteia-nos com uma certa solidez, uma certa segurança que se desdobra potencialmente em ações, em concreções. Mas que também acomoda, vicia, prende, esvazia. Possibilidades que se bifurcam na transversalidade dos tempos e espaços habitados, trocados, na forma como os tecemos.

A Escola da Arte Andanças existia na tensão entre modos de funcionar que, em parte, herdavam uma estrutura composicional/funcional de academia de dança e de outra, buscava realizar um pensamento que se pautava na perspectiva de funcionamento de um atelier, uma casa, um estúdio.

Intitular-se Escola e não academia já traz em si uma preocupação ou um viés pedagógico, de não assemelhar-se ao modo de ensino desta, na medida em que, nas 
academias de dança fortalezenses, faltava o gosto pelo particular, pela individualidade, onde o respeito aos processos individuais não era uma exigência e apelo estético, ético, mais sucumbia a outra lógica, que contemplava a competição, a exposição e o retorno financeiro. O Andanças não abraçava tais aspectos, antes, buscava um tempo-espaço que era próprio, construído, distendido de acordo com a singularidade de cada proposição, artista e aluno.

Dentre as formas de manutenção e funcionamento da Escola, havia a divisão de tarefas, a mensalidade dos alunos, as contrapartidas dos bolsistas, as apresentações e cachês voltados para aluguel, contas, as parcerias em projetos sócio-culturais. Não obstante tal empenho, a Escola veio a fechar por falta de condições financeiras.

Em 1998 o Andanças e o SEST/SENAT (Serviço Social do Transporte/ Serviço Nacional da Aprendizagem do Transporte) começam uma parceria. No edifício de três andares, ocupamos e adaptamos uma sala no térreo, para ensaios e aulas. $\mathrm{O}$ associados pagavam uma taxa simbólica e os não-associados pagavam valores entre $\mathrm{R} \$ 10,00$ a $\mathrm{R} \$ 30,00$ a depender das opções das aulas: teatro (infantil e adulto), acrobacia, sapateado, alongamento. Durante nossa estada, alguns projetos foram desenvolvidos, como o Projeto Dança no SEST (para formação de platéia, com apresentações de espetáculos de grupos e estilos diversos. Havia uma segunda temporada para aqueles grupos que a platéia votava para rever); mostras de vídeo, oficinas de artistas convidados, mostra coreográfica (trabalho autoral dos alunos) e apresentações dos trabalhos dos alunos de teatro orientados por mim ou Andréa Bardawil.

Tal parceria perdurou até o ano seguinte, ano este em que ficamos meio órfãos, tentando caminhar com uma certa ausência da Bardawil. Por algum tempo, problemas no joelho colocaram-na de molho, um tempo mínimo que parecia um século. Não obstante as intempéries foi um ano grávido, permeado por redescobertas, recolhimentos, 
atenções e necessidade de arejar e produzir. Ela dizia estar em um período de transição. Foi difícil administrar aulas, orçamentos, ensaios. Todos nós estávamos passando por adaptações, fazendo uma passagem, ou várias: estávamos em outra sede (a Escola havia fechado), com outras dinâmicas e outras demandas oriundas dessa nova parceria com o SEST/SENAT. A maioria de nós havia passado na seleção para o Colégio de Dança, enfim, um momento que nos exigiu também muita disponibilidade. Foi também nesse interregno que a maioria de nós se registrou profissionalmente e se sindicalizou.

A implementação do Colégio de Dança foi um momento ímpar para a dança cênica cearense. Consistia em um curso de capacitação profissional em dança, sediado no anexo do Theatro José de Alencar (Fortaleza-Ce.), de autoria de Flávio Sampaio, criado em 1999, junto ao Instituto Cultural Dragão do Mar. Priorizava três eixos: bailarinos, professores e coreógrafos. A singularidade do Colégio de Dança residia, entre outras coisas, no fato de possibilitar o encontro entre estudantes e profissionais, de Fortaleza e de fora do estado, que até então nunca havia se dado de forma tão intensa, sistemática e irreversível. Via-se numa mesma sala, fazendo aula de dança, balé clássico, composição ou interpretação, pessoas advinda do balé, do contemporâneo, de níveis e experiências distintas, mas que ali partiam de um zero comum, de um dado novo para todos: o estar juntos, num lugar que não era o grupo ou a companhia, não era a academia de dança, não era o projeto social, era algo novo e inusitado ${ }^{17}$.

Nesse período demos continuidade às mostras coreográficas, criamos o Projeto Dança no SEST, recebemos convidados importantes como o Luís Mendonça, entre outros, e produzimos mostras de vídeo (exposição de documentários sobre dança e teatro físico, videodança, videoarte, com posterior debate).

\footnotetext{
${ }^{17}$ Hoje, anos após o término do Colégio de Dança, viabilizou-se o Curso Técnico em Dança (parceria SESC/SENAC), uma possibilidade de formação coordenada por Andréa Bardawil.
} 
Em dezembro de 1999 mudamos para o Alpendre - Casa de Arte Pesquisa e Produção, onde a Cia. vem desenvolvendo suas atividades até hoje. Na verdade, permanecemos por um breve período nos dois espaços, até finalizarmos a parceria com o SEST e assentarmos nesse novo espaço finalmente. Nessa transição, Andréa Bardawil cuidou para que nossos primeiros contatos com a sala e o galpão fossem ritualizados. Organizou com as ex-integrantes da Cia, as bem do início, algumas aulas, conversas, trocas na sala de dança do Alpendre, que ainda estava em fase de reforma. Também levou um livro, Reinações de Narizinho, de Monteiro Lobato que inspirou um dos espetáculos da Cia., "O Circo no Pica Pau Amarelo". E lemos, e ouvimos, e brincamos e dançamos e conversamos... Não obstante esse arcabouço poético e esse abraço "materno", o estar no Alpendre nos imprimiu uma quebra de rotina que vínhamos tendo desde a Escola da Arte Andanças e continuado no SEST/SENAT, que diz respeito ao número e diversidade de aulas que dávamos e fazíamos. No Alpendre as aulas se reduziram às de dança (ministrada por Bardawil), algumas de acrobacia e teatro, às aulas variadas nos sábados, às aulas de convidados, enfim, e aos ensaios da Cia. Tal mudança poderia ter sido um elemento desestabilizador no funcionamento do Andanças, como cogitou Angela Souza ao refletir sobre essa reorganização do trabalho.

O Alpendre, enquanto vicejava a singularidade de levar a efeito uma proposta multidisciplinar em que coexistiam e se interpenetravam as linguagens e os processos e as conversas e as obras, num ato contínuo de contágio e contaminação, via-se às voltas com manobras e estratégias para garantir a sua existência. A manutenção do espaço pedia um grande esforço de todos os sócios, que se dava de forma assimétrica e distinta. A Cia. participava então na viabilização de aulas, projetos e produções.

É interessante perceber que abster-se de uma lógica dominante é comprometerse, mesmo que sutil e temporariamente, com uma certa radicalidade, posto que assumir 
um trabalho de construção é sempre, ou quase sempre, desbravar e confrontar territórios, remexer e criar raízes. Momentos que pedem um isolamento ou uma cumplicidade com afins. Dito de outro modo, não basta só o desejo de criar, uma vez que tal desejo implica também o ato de criar/ dar condições para que a criação possa acontecer no melhor sentido do que podemos entender como acontecimento. E aqui os encontros, as trocas, os diálogos, as parcerias, a alteridade.

No Alpendre, responsável pelo núcleo de dança, o trabalho da Cia ganha novos traços. Novos espetáculos são montados, cada vez mais na interface com outras linguagens - A Dança de Clarice (2000); Furdunço (2001); Vagarezas e Súbitos Chegares (2001); O Tempo da Delicadeza (2002), trabalho premiado pela Bolsa Vitae de Artes, que gerou o espetáculo e um vídeo-dança, realizado pelo vídeomaker Alexandre Veras; O Tempo da Paixão ou O Desejo é um lago azul (2005), livremente inspirado na obra do artista plástico Leonilson; Os Tempos (2008).

Aqui a Cia. já se desdobra em possíveis outros formatos e agregados. Tanto que, por algum tempo, boa parte das atividades, projetos e estudos são efetivadas e assinadas enquanto Núcleo de Dança do Alpendre, formado por artistas e profissionais diversos.

Em 2005, a Cia conclui, junto com os pesquisadores do núcleo, o projeto Interferência: San Pedro, pesquisa trabalhada na interface entre as linguagens da Dança, da Literatura e do Vídeo, que resultou na produção de mais um vídeo-dança (San Pedro), de um vídeo documentário (Um navio à deriva) - ambos exibidos na TVC -e numa publicação do Núcleo, a revista Interferência: San Pedro. Em 2006, com o prêmio Klauss Vianna, a Cia consegue manter uma série de atividades de formação, ao longo de seis meses: disponibilização de acervo, aulas gratuitas para atores e bailarinos, curso e mostra de vídeo-dança, encontros com coreógrafos e artistas (projeto entrelugares).

Em 2010, com apoio do Prêmio Klauss Vianna, a Cia realizou o projeto Tecido Afetivo - Por uma Dramaturgia do Encontro, que reuniu 30 pesquisadores do Ceará e de diversos Estados brasileiros, em torno da discussão sobre Dramaturgia. ${ }^{18}$

\footnotetext{
${ }^{18}$ Extraído de: http://www.alpendre.org.br/Alpendre/NúcleodeDança-Andanças.htm, em 15 de fevereiro de 2011.
} 
Neste ano de 2012, a Cia e o Alpendre deram início ao projeto Habitação Alpendre ${ }^{19}$, que foi contemplado com o edital Prêmio Procultura (Funarte) de estímulo ao Circo, Dança e Teatro 2010. Além de encontros quinzenais e/ou mensais (Modos de Vida) sobre economia sustentável, permacultura, etc., há o desenvolvimento de rodas de improviso, oficinas/ residências (Morada de Artista) e temporadas de espetáculos dos grupos residentes no Alpendre. Também integra o projeto uma série de palestras, conferências e/ou cursos de artistas e pensadores, de outras áreas ou afins, no transcorrer do ano.

\section{2 - Entre referências e pertencimentos}

Quando me envolvi, de 1995 a 2002, no trabalho da Cia. da Arte Andanças, foime revelado um outro caminho, uma outra forma de entender o corpo e de concebê-lo potencialmente poético, autônomo, criador. Isto se dava pela atenção e cuidado ao que particularizava cada integrante, bem como ao investimento nas relações que fugiam ao lugar comum, melhor dizendo, trabalhava-se com um incômodo/problema que se por um lado não era confortável, por outro instigava o prazer da busca e da descoberta. As minudências de falas, gestos, sons, pensamentos eram valorizados, as diferenças de ‘inflexões' eram desejadas e compunham uma organização singular. A construção técnica e poética se fazia pelo diálogo tanto das possibilidades como dos possíveis ${ }^{20}$. Assim sendo, as experiências do movimento, sua apreensão e descoberta, sempre aconteciam num espaço-tempo recortado por diferencialidades. Esse ecletismo

\footnotetext{
${ }^{19} \mathrm{http} / / /$ habitacaoalpendre.com/

${ }^{20}$ A questão do possível em Deleuze é vista como algo que não está dado ou esboçado a priori, ou ainda o que vai acontecer em conseqüência de, mas diz respeito a algo inventado, não pré-visto, não causal. Segundo Paulo Oneto: “Como podemos depreender do pensamento de Gilles Deleuze, a questão da criação em sentido forte não é nunca realizar um possível, mas tornar possível. Do mesmo modo como, para Paul Klee, a questão das artes plásticas nunca poderia ser realizar uma obra capaz de reproduzir o visível, mas sim tornar visível algo que estaria invisível no visível” (ONETO, p.199).
} 
propiciava uma abordagem corporal cujos resultados eram ricos em contrastes e detalhes, porque existia confronto, complementaridade, contradições, daí surgindo ou sugerindo uma outra coisa, um território criado pela mão de cada um, construído por cada pessoa e alheio a cada uma delas, em que todos podiam entrar e sair, deixar e levar algo, um processo de construção, troca e imanência.

Na Companhia, as aulas também eram variadas: sapateado, acrobacia, teatro, clássico, alongamento, canto e dança contemporânea. Trabalhávamos com técnicas de sensibilização corporal (dinâmicas com fragmentação corporal, jogos de manipulação e massagem), jogos dramáticos verbais e não verbais, improvisação e composição coreográfica, exploração dirigida e codificação de movimentos, pré-expressividade e alteração de energia (o trabalho de exaustão, quebra de resistência corporal e de padrões de movimento $)^{21}$ tudo quanto por si só já gerava sensações e projetos diferenciados.

Em agosto de 1996 criamos o núcleo de teatro - Andanças. Talvez os outros núcleos (de dança 'dançoxribonucleico', de iluminação, de sonoplastia, de figurino) datem desse período. O intuito era conhecer teórica e praticamente o trabalho do atorbailarino. "Optamos por iniciar estudando Stanislavski, Brecht, Artaud, Meyerhold, Grotowski e Barba, nessa ordem, relacionando e comparando suas inquietações e suas propostas de trabalho" (arquivo pessoal, s/d.). O núcleo era aberto para interessados em geral e a princípio composto por mim, Evaldo Silva, Sâmia Bittencourt e Acleilton Vicente.

Nas leituras e discussões dos grupos de estudo de teatro e dança nos encontrávamos com Grotowski e seu 'teatro pobre', com Eugênio Barba e a Antropologia Teatral, ambos constituíam pilares do trabalho corporal e teórico em correlação com o desenvolvimento de técnicas utilizadas pela dança contemporânea. A

\footnotetext{
${ }^{21}$ Extraído do programa do curso "Treinamento corporal para atores e bailarinos", 15 a 21 de janeiro de 2001, ministrado por Andréa Bardawil.
} 
bem da verdade, tudo acabava ficando mesmo muito ligado, e fomos, pois, construindo algo que permeava o universo tanto do que se entendia por dança quanto por teatro. $\mathrm{E}$ então o engodo estava feito. Isso não é dança. Isso não é teatro. E essa concomitância em cena, de pessoas de formações diversas e níveis técnicos diferenciados? Era o que comumente ouvíamos de uma área ou de outra, sempre com uma atitude de incômodo ou de crítica a algo que não se poderia rotular com clareza. Como então criar os possíveis de existência? Como passear pelos extremos sem esquecer aquilo que os constitui, que os preenche, que os extravasa? Vivendo, refletindo, conhecendo, sendo? Como querer responder questões que são tão provisórias como talvez sejam as suas respostas? Como transcender as dicotomias, superá-las sem temer o desapego à lucidez hodierna? Como trilhar sem garantias de chegar? Com que estratégias permitir os fluxos? Fluxo de quê? De informações, de conceitos, de sensações? O que está em trânsito é também o que não está? A cada passo dúvidas, achados, acasos e um sentido permanente de continuar.

Uma celeuma de questões que concernem a busca de um sentido, para além dos reconhecimentos, para além dos passos já dados. Um desassossego que dá poucas alternativas para a manutenção de estabilidades, uma boa crise, intempestiva. Na busca de um método, de uma forma de dizer, fazer o desconforto transformar-se em aconchego.

Para tantas referências era necessário algo em que todos pudessem encontrar um eixo, uma base ou uma experiência em comum, um ponto de convergência. A própria Cia. já viabilizava essa possibilidade, pela pesquisa teórica e prática a partir do trabalho corporal.

Aqui a intensidade fez-se caos e abriu caminhos. Indagações que advinham de outras que residiam em uma única questão: “como?”. Então, ao estar de frente para a 
criação de uma cena, de uma personagem, de uma não-personagem, de uma coreografia ou de uma simples ação, do planejamento de aulas, de programas de cursos, num eterno exercício de recomeço, acudiam todas as dúvidas possíveis.

À época de seu surgimento, na década de noventa, o estado do Ceará é atravessado por uma série de mudanças e inovações. Dentre as construções de destaque podemos citar o Centro Cultural Dragão do Mar (complexo cultural com cinemas, teatro, anfiteatro, auditórios, museus, biblioteca, salas de exposição, planetário, salas de aula, livraria, restaurante, praças e bares) e a reestruturação da Praia de Iracema, situando o entorno como um pólo artístico-cultural de bastante significação e projeção no cenário local e nacional. A reforma do Theatro José de Alencar (de 1989 a 1991) também trouxe novo sangue às artes cênicas, tendo na programação de sua reinauguração, entre outras, apresentações e workshops de Peter Brook, Eugênio Barba, Ariane Mnouchkine, Denise Stoklos e Grupo Corpo. Em 1996 surge o Instituto Dragão do Mar de Arte e Indústria Audiovisual do Ceará, de onde foram criados o Centro de Dramaturgia (formação de roteiristas, dramaturgos e produtores), o Centro de Design (design industrial e artesanal), o Curso de direção Teatral e o Colégio de Dança do Ceará, todos com o intuito de qualificar e formar mão-de-obra para o mercado de trabalho de entretenimento, lazer e cultura. Em 1997 ocorre a I Bienal de Dança do Ceará, um acontecimento que desencadeou outros processos de articulação da classe da dança, em busca de formação e políticas públicas (GADELHA, 2006, p.290-292). Aspectos que interferiram na e reestruturaram a arquitetura do Ceará, alterando seu fluxo de funcionamento, seus ritmos, seus habitantes, sua imagem, seu modo de ser: há uma reviravolta no urbano e no rural: aeroporto, metrô, infovias, obras hídricas, porto, saneamento (GADELHA, 2006, p. 247). 
Esses fluxos dinâmicos da cidade, que começaram a incomodar a dança cearense no início da década de 1990, criando no corpo do bailarino um território de conflito e contradição, o colocou, nos anos posteriores, em 'condição de'. Condição à experimentação, à construção de um pensamento em conjunto, um pensamento em ação; condição para a criação do possível (GADELHA, 2006, p.249)

Nesse período a dança cênica cearense buscava por algo diferente, nos dizeres de Gadelha (2006, p.267): 'Não havia a proposta de 'formar' uma nova mentalidade, mas ‘inventar' uma outra mentalidade, 'algo diferente'”. Andréa Bardawil ${ }^{22}$, diretora da Cia., falando em entrevista à Rosa Primo, declara que procurava por algo que não sabia o que era e, para tanto, deixando de trabalhar com bailarinos já formados pôs-se a trabalhar com iniciantes e atores, em busca de algo que ainda não tinha visto. Percebemos que as andanças urgiam fazer-se em outras paragens, descobrir-se no fazer.

(...) Bardawil criou a 'turma de sábado'. Essa 'turma', que funcionava no espaço onde o grupo Andanças trabalhava, era aberta à participação de qualquer pessoa, nos dias de sábado, cujo interesse fosse: fazer aulas de diferentes técnicas de dança, gratuitamente; pesquisar, inventar e experimentar seus corpos em movimentos, e/ou movimentos em seus corpos; bem como participar das leituras e discussões de textos e livros relativos ao corpo cênico.

Foi nesta turma, constituída de corpos diversos e composta, sobretudo, por pessoas sem nenhuma técnica de dança, que grande parte dos coreógrafos do Colégio de Dança - Karin Virgínia, Gerson Moreno, Ângela Souza, Fauller, Márcio Slam, entre outros criadores e bailarinos alunos do Colégio - deu início a seus primeiros estudos e pesquisas em dança; cujos trabalhos, apresentados atualmente, tornaram-se referenciais da dança contemporânea no Ceará. (GADELHA, 2006, p.279-280).

GADELHA (2006) também nos deixa claro que coabitavam essas verves criadoras - um fluxo intenso de (des)(re)construções - e a permanência de códigos e processos de formar tradicionais, que em sua maioria, deixavam pouco espaço para o

\footnotetext{
${ }^{22}$ Coreógrafa e diretora da Companhia da Arte Andanças desde 1991. Participou dos projetos Rumos Itaú Cultural Dança e recebeu Bolsa Vitae de Artes em 2000. Foi Assistente Artística do Colégio de Dança do Ceará em 2003. Atualmente é coordenadora do Núcleo de Dança do ALPENDRE - Casa de Arte, Pesquisa e Produção, do Curso Técnico em Dança (Senac, Secult e Centro Cultural Dragão do Mar) e da Bienal Internacional de Dança do Ceará.
} 
exercício criativo. Nesse ínterim, a Cia. da Arte Andanças, mostrava-se, e mostra-se, como possibilidade catalisadora dessas necessidades e buscas.

Observar o processo de mutação da dança cênica no Ceará, certamente tem como uma de suas linhas marcantes a existência do Andanças. Do tempo em que começou sua produção, 1992, ao Tempo da Delicadeza, 2002, vários entrelaçamentos dessas linhas resultaram em modos diferentes de pensar e realizar dança. Mas isso não foi exclusivo do Andanças, da mesma forma que não é exclusivo do Andanças a potência política de resistir e criar, de produzir e fazer variar as formas de vida - embora o Andanças tenha papel crucial nesse processo (GADELHA, 2006, p.256)

Logo em seu início, o Andanças - como familiarmente é chamado - teve uma reviravolta em seus pressupostos, a partir de seu primeiro espetáculo, em 1992, enquanto companhia que buscava no corpo outras referências. A experiência singular com a Tânia Nardini foi uma divisora de águas - "O que a Tânia deu de mais concreto pra gente foi a idéia que podia haver um caminho construído" (Bardawil) - e uma possibilidade de um sentido outro.

Foi no processo de criação do musical infantil de sapateado "Dando no pé" que as primeiras transformações e rompimentos foram se concretizar. O espetáculo tinha como tema os meninos de rua, direção da bailarina e coreógrafa carioca Tânia Nardini. (...) Esse espetáculo foi fundamental para a descoberta de uma nova ética ${ }^{23}$ de trabalho, a qual tudo partia do corpo e nele se fundamentava. Abriam-se as portas para novas formas de ver o corpo e uma nova visão da construção de um trabalho artístico. Essa experiência transformadora para o grupo teve conseqüências diversas, "algumas desistiram de andar e outras foram atrás de responder às suas inquietações batendo pernas" (Bardawil, 2000), isto é, algumas bailarinas desistiram da companhia ou de dançar e outras foram estudar dança noutras cidades. (ARAÚJO, 2006, p.41)

Neste espaço de busca individual, de identificação com propostas, de motivações ou resistências as mais diversas em relação a expectativas, domínios e objetivos,

\footnotetext{
${ }^{23}$ Ética entendida como princípios de conduta para o trabalho de pesquisa corporal do grupo.
} 
adentramos um campo de incertezas. Por conta de divergências de pensamento, o grupo que teve sua origem dentro da academia de dança (Academia Cláudia Borges), acabou por romper com esse vínculo, quando procurou trabalhar de forma mais independente. Em 1994, é fundada a Escola da Arte Andanças, um espaço de encontros, não somente para aulas, mas para discussões, experimentações, achados e perdidos. Foi nesse contexto que me aproximei deste território, construindo-o e reconfigurando-o.

E, continuando entre os diários de bordo, expomos uma das indagações compartilhadas pela cofundadora e diretora da Cia., Andréa Bardawil, com o grupo:

Aglutinar, conciliar e liderar traz um risco inevitável: o da cristalização de verdades. A cobrança por respostas nem sempre chega junto com a percepção e a segurança de que dirigir não depende de sabermos todas as respostas, e sim de conseguirmos instigar as perguntas corretas. Nos instantes mais caóticos, quando quase perdemos a fé, é que vamos absolutizando algumas verdades, coisas em que precisamos acreditar, para dar o próximo passo. (...) Quais são as respostas corretas? Qualquer uma que desperte nossa atenção e curiosidade, que com isso também será desperto nosso desejo. E como já disse um amigo meu bem acolá, "não construímos bons encontros pela falta, mas sim pelo desejo, com a afirmação do outro, do outro como afirmação da alteridade'. Todas as perguntas são corretas. (Andréa Bardawil, Sobre liderança, direção..., 1999).

Estas reflexões se davam pari passu aos processos de criação e aula. Que exigências permeavam uma e outra? O que se esperava de processos e resultado nessas instâncias? $\mathrm{O}$ que se criava na leitura do trabalho artístico/docente enquanto configuração de relações de poder? Possíveis tiranias? Aberturas que geravam enquadres, responsabilidades, inflexibilidade? Que me fique a dúvida da experiência conjunta e não óbvia, que me fique o desejo do buscar, e não necessariamente do encontrar, arremedando Clarice Lispector. Sigamos, pois, outras vozes que se aproximam para entranhar e estranhar nossa maneira de perceber.

Passos adiante e entramos em contato com o Lume (Núcleo Interdisciplinar de Pesquisas Teatrais - Unicamp), quando metodologias e finalidades foram relacionadas. 
Sobre esse momento, transcrevemos um trecho de entrevista feita por Andréa Lopes a Andréa Bardawil, quando da sua pesquisa sobre as Matrizes estéticas de grupos de dança emergentes do Nordeste, pela UFBa:

É mais legal falar de troca do que de influência, porque isso nos fez perceber que realmente conseguimos traçar um caminho próprio, a partir dos mesmos princípios que eles trabalham. Algumas vezes utilizamos uma das técnicas desenvolvidas por eles, mas é muito bom saber que desenvolvemos nossas técnicas de alteração de energia, por exemplo, e podermos conversar sobre os resultados com eles. (LOPES apud ARAÚJO, 2006, p.74).

Percebemos que a relação é dialógica e não necessariamente confluente em todos os seus aspectos. Mais uma vez despontam singularidades. A noção de diálogo ${ }^{24}$ discutida por esse autor não se limita ao que é complementar ou harmônico somente, mas ao próprio conflito de idéias, valores que estão, direta ou indiretamente, em contato. A utilização de alguns de seus conceitos e pensamentos são usualmente dimensionados na esfera do verbal, literário, lingüístico e, sobretudo, no âmbito de questões pertinentes à natureza e funcionamento da linguagem e dos discursos. Nessa perspectiva dialógica podemos perceber em um determinado processo de criação e sua estruturação metodológica como se dá o entrecruzamento de discursos, de 'falas', que acordos ou dissonâncias quando da relação de alteridade, da presença do outro que está implícita ou explicitamente no processo enquanto elemento fundante e direcional. Seria este um componente a redirecionar as orientações metodológicas de aulas, ensaios e montagens? Que tipo de trabalho pode ser tecido quando se estimula a experimentação/confronto com o outro? As singularidades, as individualidades, as

\footnotetext{
${ }^{24}$ Foi Brait quem asseverou "Bakhtin, repetimos, considera o dialogismo o princípio constitutivo da linguagem e a condição do sentido do discurso. Insiste no fato de que o discurso não é individual, nas duas acepções de dialogismo mencionadas: não é individual porque se constrói entre pelo menos dois interlocutores, que, por sua vez, são seres sociais; não é individual porque se constrói como 'um diálogo entre discursos', ou seja, porque mantém relações com outros discursos". (BRAIT, p.32: 2005).
} 
diferenças são limites, convenções ou possibilidades de troca, de aprendizagem, de intervenção nas ações pedagógicas/ práticas educativas?

Angela Souza, refletindo sobre o que se plantava e o que se colhia na Cia., e também sobre como percebia tais desdobramentos com relação ao encontro com o Lume, observa:

Mesmo que eu não entendesse... e visse... eu sentia o resultado daquilo. Mesmo que eu não conseguisse, por exemplo, reter a energia depois, ou reelaborar, eu sabia que isso era uma dificuldade, que naquele momento eu achava que era só minha, não é... eu sei que é uma dificuldade do processo, o processo tem que desenvolver dentro dele mesmo estruturas para que ajude a lidar com tudo isso, né? Acho que o encontro com o Lume me dá essa clareza muito maior. ${ }^{25}$

Compreender e discernir sobre esse processo de incorporação técnica e procedimental, apropriando-se de princípios de trabalho, entender a demanda de um aprendizado e das dificuldades inerentes a esse trabalho (como, por exemplo, a dinâmica de exaustão, os princípios que retornam), perceber e refletir o percurso metodológico, foram aspectos que Angela viu como fatores que amenizavam os obstáculos tornando-os transparentes. Ainda em diálogo com o Lume, acrescenta:

Eu gosto muito dessa nova demonstração técnica do Simioni, que ele diz assim, que ele vai falando dos vários mestres e ele diz assim: 'todo mestre lhe pede uma coisa, e aí ela me pediu que eu fizesse... dançasse só a alma, só que todo mestre quando pede uma coisa também indica um caminho'. Então é aprender a indicar um caminho, porque também a pessoa vai ter que descobrir, né?

Desvendando camadas de um saber-fazer, de um saber-aprender, de um saberdar. Cultivando uma generosidade e uma humildade como algo que se constrói no subliminar de comandos, de solicitações, de proposições, enredados numa escritura que se faz conjuntamente e de forma única. Sopesar forma e conteúdo, ou qualquer outro par que inspire dicotomia, deixando-se contaminar pelo sabor das intenções, percebidas

\footnotetext{
${ }^{25}$ Entrevista concedida em 17 de novembro de 2011.
} 
antes, durante e depois dos processos de criação. Se permitir dizer, se permitir encontrar. Ângela atina para o caminhar conjunto, um andar de reveses e cuidados mútuos, nem sempre explícitos, nem sempre vislumbrados, mas que tornam crível e aderente o processo de trabalho em que se está imerso.

A ideia de processo de trabalho se constitui por vezes de forma tão impregnada, que se torna uma verdade, um modo cristalizado, uma imagem estagnada, uma fórmula. Daí a importância de habitar paisagens diferenciadas e gerar outros cruzamentos e expectativas. Daí a importância do falar, do refletir, do encontrar outras referências, que afirmam ou fragilizam as anteriores, mas sempre de um outro ponto de vista.

Os artistas da Cia. mesclavam suas experiências anteriores e simultâneas compartilhando um entendimento multifacetado de um estar em processo de trabalho corporal, que envolvia riscos, rigores, e uma ética comum, construída no aqui-e-agora e também respaldada no fazer de cada linguagem.

O Acleilton era muito carrasco (...). E já era dele, né? (...) Ele sempre foi assim. duro na queda, né? Foi um aprendizado muito bom na FlicFlac. Porque eu de fato, não sabia como era ensinar, dar aula daquilo tudo, nem como era a ética, porque tem uma ética do artista, né? Então era tudo muito estranho ainda, né? (...) A virtuose do circo e o treino pede isso também, que se não for com esse rigor, não funciona, porque o circo dói muito. Então se eu não tiver esse rigor que rege, eu desisto (Sâmia Bittencourt, novembro,2011) ${ }^{26}$.

Nessa fala de Sâmia, quando faz referência à persona maestra do Acleilton e ao modo de funcionamento da Flic-Flac ${ }^{27}$, coloca-se a partir do que observa dele, falando também dela mesma, definindo-se aqui no e pelo outro.

\footnotetext{
${ }^{26}$ As demais citações de Sâmia Bittencourt, advém da entrevista a mim concedida para esta pesquisa, em 14 de novembro de 2011

27 A Flic-Flac, sob direção de Acleilton Vicente, laborava com a linguagem de circo, privilegiando acrobacia de solo, clown e dança. Muitos dos integrantes, a saber, o próprio Clê, Sâmia, Evaldo, Milton e Brino, foram membros do Andanças.
} 
Sâmia, que teve uma experiência com Oswald Barroso ${ }^{28}$, na pesquisa em cultura popular, menciona: "Eu queria tudo e no Oswald eu tinha o leque, a porta aberta pra fazer tudo. Porque era o popular, o brincante, ele faz tudo. Eu fui formada informalmente nesse fazer tudo, entende? (...) É tudo junto mesmo, né? Que é o popular, que eles não separam isso.”.

Mas na medida em que se integrava à esta ou àquela Cia., os projetos estéticos iam afunilando as escolhas, o junto vai se separando. Ainda sobre sua experiência em outros grupos, ela acrescenta:

Você aprende a investigar, não é só montar né? Essa era a grande questão, porque a Mais $\operatorname{Caras}^{29}$ ela era o espetáculo, não fazia outra coisa a não ser o espetáculo... eu aprendi com o Oswald a tá lendo, a tá buscando, a tá dentro de campo, indo lá, conversar, fazer pesquisa, gravar a entrevista com os mestres.

Em sua monografia, Angela Souza, ao falar sobre sua trajetória artística, deixanos exposto que quando ela se aproxima mais do universo da dança/ teatro, começa a sentir-se instigada a refletir sobre as formações clássica, moderna, contemporânea e sua eficácia; sobre criação e experimentação coreográfica; sobre o entendimento da técnica clássica como base única e legítima para se dançar qualquer coisa; atenta para a necessidade de liberdade de expressão que a conduz na busca de um espaço/ tempo para fluí-la. Ter experimentado outras possibilidades no Andanças, trouxe outras inquietações advindas do trabalho de pesquisa de movimento desenvolvido nas aulas e treinamentos, em que reflete tanto a partir do lugar do intérprete-criador quanto do criador-intérpete, ponderando:

Eu fazia todas as aulas, as minhas dificuldades eram dificuldades normais, eu acho assim, dificuldades de flexibilidade, de força,

\footnotetext{
${ }^{28}$ Pesquisador de cultura popular, diretor, escritor e dramaturgo cearense.

${ }^{29}$ Grupo cearense formado por Claudio Ivo, Samia Bittencourt e Acleilton Vicente que trabalhou durante quase dez anos, apresentando intensamente nesse período a montagem clownesca "Nada, Nenhum e Ninguém".
} 
dificuldade de memorização. Para mim, o que pegava mais era como lidar com as ferramentas que me eram dadas, por exemplo, para lidar com o processo criativo. Como por exemplo: "Ah, repete". Improvisou, repete. Repete.... Como? "Que é que você me dá pra ajudar... Eu passei três horas improvisando numa viagem... que você quer que eu repita?" Eu acho que isso é uma questão técnica que ainda me pega, quando eu penso em criar com alguém eu penso em como dar as ferramentas. (Entrevista, 2011) (10 $^{30}$

O Andanças se propunha algo diverso do que se apresentava enquanto trabalho corporal. De certo não estava sozinho na procura por "uma forma de dizer", mas particularmente sua busca traçava e traça um diferencial investigativo enquanto metodologia e criação, abrindo-se para uma atitude experimental, sistemática, política e criativa da cena e seus processos.

\footnotetext{
${ }^{30}$ Entrevista feita com Angela Souza em 17 de novembro de 2011.
} 


\section{II - Modos de caminhar/ modos de formar}

Em que consiste a ação de formar? Em que consiste a ação de dar forma? O que significa ou no que implica esse agir, essa forma e esse dar? Se é da arte que se fala, se é pra cena que se caminha, qual a digital do 'verbo' e a impressão dos passos? Se o mérito da dúvida nos cabe, 'nem sempre nem nunca' é valsa quaternária.

Uma formação artística é constituída não só pelo que se trabalha em palestras, workshops, oficinas, cursos, academias etc., mas pelo que é articulado e rematerializado em processos de criação, ressignificando saber e produção de saber, pois o que se gesta é bem mais que conjugação técnica ou discursiva.

A imersão numa busca - de linguagem, método - ilhava-nos. Por outro lado constituiu-se como uma maneira de focalizar no trabalho aquilo que se singularizava. Esse fechar não era sinônimo de isolamento. Tal atitude proporcionava um estranhamento, no bom uso do termo. A estranheza, quando era uma reação de quem estava fora do grupo, era algo que vinha associado a um não entender aquilo que se fazia, principalmente enquanto resultado estético. $\mathrm{O}$ entendimento aqui poderia ser traduzido por reconhecimento. Aqueles que queriam ou que viriam a entrar na Cia., recorrentemente se diziam: “Eu não sei o que é aquilo, mas é isso que eu quero fazer!". Essa frase ou similares a essa, foi enunciada e colhida via depoimento/entrevista dos integrantes. Uma identificação provocada por uma não-identificação, que talvez se desse pela peculiaridade do não enquadramento, e por tudo que transparecia enquanto filosofia e pesquisa de grupo, um jeito de andar mais do que uma explicação ou exposição de um modelo:

O autêntico é alguém falando de algo que lhe é vivo, latejante, celebrando um conhecimento, sem incorrer numa dramaticidade falsa e exagerada (trágica ou comicamente), nem numa fórmula fácil e vazia de mostrar a fragilidade humana. A delicadeza, por sua vez, não 
é sinônimo de frouxidão. Ela é inalcançável se exercitada apenas externamente, como quando se pratica halterofilismo. Essa delicadeza é o mais concreto resultado do tal princípio que defende a busca pelo 'menor movimento com o máximo de esforço', e deve ser a provável expressão do corpo-em-vida, como sugere Barba. O autêntico e o delicado é alguém falando do que sabe, mesmo que fale pouco ou saiba pouco. Aliás, quem não fala do que não sabe - ou não sente acaba não sabendo pouco. Porque sabe do principal. Sabe das coisas que importam (BARDAWIL, Arquivo pessoal: Sobre minha pesquisa corporal..., 02 de fevereiro de 1998)

"Sobre minha pesquisa corporal..." constitui um dos muitos textos que a Andréa nos escrevia, às vezes diretamente provocativos (o que você acha...), outros sedutores e descritivos, outros mais didáticos, e talvez, além das reflexões sobre os trabalhos, dela e do grupo, uma incitação para se praticar a escrita, a análise, a verbalização, um escoamento. Tocar no autêntico e no delicado, ou por eles ser tocado, implica numa exigência pessoal de não aderir aos caminhos mais fáceis, talvez uma estratégia para não cair nos clichês esvaziados ou nos resultados previsíveis e aceites. Um convite para um trabalho sobre si mesmo que nem sempre massageia o ego, que nem sempre é o prazer fácil, ou, por outra, "menor movimento com o máximo de esforço", uma lógica que subverte o chegar antes ou primeiro, uma lógica em que se reforça o detalhe e a entrega e o comprometimento, e que se volta para a questão do processo - inalienável e intransferível.

Bardawil assinala algo muito próprio dela, que é o saber de si, mesmo que pouco, para depois tentar saber do outro. Não como fórmula que dá certo, mas por estranha necessidade de se ouvir. Saber do seu movimento para depois dá-lo, e encontrar caminhos para fazê-lo. Entendendo movimento não só como gesto coreografado, mas como éthos e élan ${ }^{31}$.

\footnotetext{
${ }^{31}$ Compreendendo-os em relação aos valores que permeiam o pensamento sobre o fazer artístico e o impulso criador respectivamente.
} 
A despeito ou por causa mesmo da recepção/ leitura antagônica que provocava, o Andanças seduzia, se fazia presente, propositor, provocador. Havia bastante procura pelas aulas, para se conhecer o modo de funcionamento, a pesquisa... pessoas se achegavam com o intuito de participar ou contribuir para o trabalho. Assim, as trocas vinham dos encontros, mostras, debates, das seleções para integrantes e/ou alunos.

Aulas, workshops, palestras teceram redes de encontros. Entre convites e audições a Cia. se refigurava. Num primeiro processo seletivo o que se pretendia era encontrar pessoas disponíveis, propositivas, exigentes. Não corpos necessariamente bem treinados numa ou noutra técnica específica, mas corpos abertos, atentos. Isabel Botelho, que vivenciou esse processo diz que não tinha muita flexibilidade, nem força, no entanto seu corpo, sua pessoa estavam comprometidos, inteiros, no que era proposto, e que ela buscava realizar da melhor maneira possível dentro das limitações que se lhe apresentavam no momento. Ressalta que sua forma de articular as informações no corpo, de tratá-las, redimensioná-las, foi um dos motivos, talvez o motivo, que a fez ser selecionada.

Na segunda grande audição teve muita gente. Para as pessoas que não entraram, foi criada a turma de sábado. Como nem todos tinham a disponibilidade ou o interesse em participar dessas aulas, então as vagas foram disponibilizadas para outras pessoas que não somente as que tinham participado do processo de seleção. É curioso que a maioria dos entrevistados não se lembre com detalhes de como foram as audições. O que se verifica é que tal seleção tratava-se de fazer algumas aulas de dança, teatro, acrobacia... ministradas pela Bardawil ou por outros integrantes da Cia.

Tais audições consistiam, geralmente, em aulas cuja estrutura compreendia um momento de alongamento/aquecimento, a transmissão e reprodução de sequências simples de movimento, bem como espaço para a improvisação menos ou mais 
direcionada. Esse aquecimento inicial podia conter elementos e procedimentos da acrobacia (força, atenção, risco) e/ou específicos da dança contemporânea (como a exploração de níveis, fatores de movimento etc.) e teatro (trabalho energético). Às células de movimento coreografado era dado um tempo de estudo e apropriação e, por vezes, desconstrução das mesmas, já adentrando em improviso individual e/ou em interação com o grupo. Havia, ao final, uma "volta à calma", que podia ser a retomada de um estado ou propositura do início da aula, ou um relaxamento conduzido (em posição ereta ou deitada) sempre remetendo a uma sensação, a um sentir o corpo, a percebê-lo.

Todos os que passaram na audição tinham que dar aula, alguma aula que pudessem organizar. Nisso, tivemos aula até de etiqueta. Seria essa uma forma de deixar o grupo mais coeso, de exigir mais de quem estava entrando, de compartilhar saberes inauditos e não prescritos, de testemunharmos e vivenciarmos trocas de papel (alunoprofessor)? Depois, como forma de entrada no Andanças, permaneceram como estratégias o convite e o estágio, ou a simples aproximação dos/nos trabalhos com a Cia.

Das 14 ou 15 pessoas aprovadas, continuaram pouco mais de meia dúzia. As exigências do trabalho no transcorrer do tempo também se constituíam como processo seletivo. Passados alguns anos, logo depois dessa última audição, chegamos num conflito relativo à participação, disponibilidade, um limite para a associação e comprometimento com outros projetos. Houve uma época em que a flexibilidade, ter mais ou menos, foi a pauta em voga. Estaríamos numa crise? O que exigir do outro? E porque ter que falar de uma disponibilidade que outrora fluía sem ninguém ter que? Como tornar o que o outro podia oferecer suficiente para o desenvolvimento do trabalho? Parecia que o perfil das coisas começava a mudar. Não conviria caminhar como no início... O encantamento que senti deu lugar a um estranhamento que por sua 
vez diluiu-se em um novo encanto. Ondas de calor e frio alimentando sensações de proximidade e distância, de coletivo e de indivíduo, de pertencimento e de não, de ser ilha e ser mar.

Faltava-me uma atitude de aceitação e uma perspectiva de que o trabalho poderia continuar sendo feito só que com outras matizes que não aquelas que eu via como funcionais e imprescindíveis, mas, por outro lado, precisaria de um amadurecimento que à época não existia. Esse assunto deveras me incomodava porque tinha me identificado com a disciplina, o rigor e as escolhas feitas até então. Para mim aquele modelo de processo era ideal, funcional e redondo, resolvido. No meu entendimento se a coisa afrouxasse perderíamos o norte. Bastaria uma fresta para que a abertura fosse dilatada, e então, para todas as concessões que antes não havia, ou se havia, muito pouco. Trabalhoso ter de me acostumar com novos parâmetros. Faltava-me o desapego necessário para a construção de um outro caminhar. Por que mudar se estava tudo dando certo, as mil maravilhas? Esse era meu pensamento. Mal sabia eu, ou não queria ver, outros olhares e desejos que, em se misturando, não podiam responder somente ao que eu desejava. O fato é que lidar com a diferença tira-nos o chão... Como estarmos inteiro naquilo com o qual não nos identificamos de pronto, que não nos é confortável, seguro? Entrar na flexibilidade era jogar-se no escuro... aliás, hoje, pareceme que discutir sobre isso não era a questão em si, mas um dos vieses operacionais que se apresentava. A questão era que os desejos não cabiam mais naquela forma.

Se o teatro é aquilo que acontece no entre, reitera-se - assim como Grotowski o fez - a arte do encontro, do contato vivo e 'inaugural', das transversalidades, simultaneidades e afetividades. Não se situa num lugar, mas numa dinâmica. Um espaço-tempo possível para não estigmatizar as relações, antes construí-las. 
Formar é criar e configurar novas poéticas de tradução e traição... Construindo uma outra condição. Respondendo ao que nos afeta e entendendo resposta não necessariamente como solução, mas como eco, vibração, sentido ou efeito de sentido, quiçá outra pergunta.

\subsection{Do treinamento corporal}

Haveria uma técnica capaz de conferir ao ator-bailarino iniciante, ou que não tivesse experimentado a formação clássica, uma presença cênica que propiciasse uma qualidade de movimento explícita e inquestionável? $(\text { Bardawil) })^{32}$

A pergunta acima remodela uma anterior: Haveria uma base técnica além do clássico? Que vem no desdobramento de outras: a técnica é importante, imprescindível? A técnica ou as técnicas? Qual o lugar da técnica e como entendê-la na perspectiva do plural e do diferente? O ator-bailarino iniciante apresentaria uma maior disponibilidade para a investigação de novos parâmetros de trabalho, teria ele um corpo menos informado e mais aberto? É possível uma mensuração? A partir de que valores e de que referências? Um apurado nível técnico poderia ser um entrave? Ou, aquele que se inicia numa pesquisa/ investigação/ experimentação corporal acenaria para a possibilidade de inscrição de uma qualidade de movimento não necessariamente vinda de técnicas já dadas/ codificadas?

Lidar com uma heterogeneidade corporal na perspectiva de incorporação de uma presença em que as pessoalidades compõem e são, ao mesmo tempo, partida e chegada para o trabalho, a força motriz, traz a ideia de uma corporalidade construída, observada,

\footnotetext{
${ }^{32}$ Fragmento do texto escrito para palestra conferida na UNIFOR em maio de 2000. Com o seguinte tema: O corpo no Espaço Cênico.
} 
remexida, enfim, do corpo como processo e não como produto. Quando de seus primeiros trabalhos com a Cia., Noara Rodrigues observa:

Acabo de entrar para a Companhia, como estagiária, e este é meu primeiro ensaio. Sinto falta de explicações, a sensação que tenho é que o bonde já andou $10 \mathrm{~km}$, e agora é que vou sair de casa para tentar pegar aquele bonde que já andou $10 \mathrm{~km}$ do ponto de saída. Está sendo tudo muito de sopetão: estar sentindo milhões de sensações ao mesmo tempo (pela manhã no Colégio de Dança e à tarde no Alpendre), sem saber para quê irei usá-las e porque tudo isso de uma vez só, sem pausas para tentar entender o que está acontecendo comigo e com meu corpo. Aí me pergunto como conseguirei atingir esse entendimento se meu corpo não passou por todos os processos que as meninas da Cia já passaram há anos. Como será trabalhar desta outra forma? Como sentirei essa 'diferença' se minha memória corporal não é igual a delas? Será que precisa ser igual? Sei lá, são tantas dúvidas... (fragmento de diário de bordo, relatório final do Tempo da Delicadeza, Bolsa Vitae, 2001)

A inquietação sentida por Noara em relação às diferenças de experiências dentro da Cia. revelam na comparação uma expectativa no que se refere ao nível de apropriação de técnicas e princípios, àquilo que o corpo já processou, apreendeu e irá ressignificar. Num mesmo movimento ela indaga sobre a necessidade dessa homogeneidade. Tal insegurança tende a arrefecer quando o respeito ao processo é constantemente reiterada. A preservação e observação de que cada pessoa tinha o seu tempo, a sua busca, seus momentos, de que as descobertas, o andar de cada um, era individual e intransferível, eram aspectos bastante prezados. A dimensão processual como referência, no feito e na feitura, esgota a compacidade do saber fechado e transmitido e obtido e findo (KASTRUP, 2007). Não há fim, mas limites provisórios. Até a técnica mais fechada, sob essa perspectiva, é inacabada. Quanto mais fechada mais inacabada, porque parou no tempo. Não se alimenta dele.

Nesse sentido, se havia algo recorrentemente almejado, era o encontro das pessoalidades com o entendimento do seu modo de fazer, perceber, construir. $\mathrm{O}$ estado de busca era uma condição alimentada. Então não cabia entender o processo do outro 
como um ponto ideal a ser alcançado. As conquistas, as perdas, as estagnações eram relativizadas ou entendidas a partir do itinerário de cada pessoa. Isso não quer dizer que as exigências, as cobranças e o desejo de equalização do que se criava, do que se queria desenvolver e repassar, o desejo de falar uma mesma língua, não fosse algo precisado e pretendido.

Tínhamos aulas em formatos mais convencionais: alongamento, sapateado, acrobacia, balé clássico... mas, principalmente ao teatro e à dança, era dada a possibilidade de uma investigação diferenciada a partir da escuta, da percepção, do direcionamento estético e poético do material levantado e construído durante a aula ou ensaio. Não era somente reconhecer, alcançar ou ultrapassar um limite de condicionamento físico. Não era só a apropriação de uma técnica corporal, embora isso compusesse junto. $\mathrm{O}$ foco se mantinha em estados de atenção, entrega, coresponsabilidade, coautoria. $\mathrm{O}$ que se buscava era uma inteireza de presença, compor com nossas possibilidades cotidianas e extracotidianas.

Se por um lado trabalhávamos aspectos reconhecidamente técnicos, por outro, e a partir deles, nos debruçávamos sobre o desconhecido. Nem tudo eram flores. Nos ensaios/treinamentos desenvolvidos pela/na Companhia, isso era ainda mais forte e mais exigido. Palavras e/ou comandos recorrentes nos processos de trabalho (preparação corporal, ensaio, aulas, montagens etc.): postura de base, extracotidiano, assimetria, menor movimento com o máximo de esforço, incômodo, trabalhar no/com o chão, peso, contrapeso, transferência de peso, fragmentação, exploração de movimentos, improvisar, contar histórias, olhos fechados, rolamentos, contenção, diferenciar ação física, gesto, atividade e movimento, 'stop', utilização da música, alteração de energia, mastigar o chão, entrar e sair do chão, encaixe, desequilíbrio, caminhadas, rodas de expressão. Havia também o criticado 'não pensa'... como assim? Faz sentido no 
contexto em que era trabalhado. Não conceber previamente o que se vai fazer, ações ou caminhos, tentar escutar o corpo de outros modos e permitir sensações, reverberações.

A postura de base consistia em manter-se atento, ereto, joelhos fletidos e abdomem conectado. A postura de neutralidade era exigida quando do início ou término de exercícios acrobáticos ou de teatro (cenas, partituras). Ambas ritualizavam os procedimentos e atitudes. Eram incômodas no sentido de distender o momento de "estar em cena". Mesmo tendo terminado a exposição daquilo que se queria mostrar ou fazer, mantinha-se um estado não-relaxado de conexão com o que foi ou o que seria visto ou feito. Por vezes uma teima com o cansaço, com a dispersão. Uma convenção que pontuava inícios, permanências e fins, tecendo-os conjuntamente.

O extracotidiano, enquanto um dos princípios que retornam enfatizados por Eugênio Barba e trabalhados pela Cia., era percebido na incorporação e/ou desconstrução das técnicas cotidianas de mover (andar, sentar, olhar) e técnicas codificadas de dança (Jazz, clássico, contemporâneo).

As experimentações eram anteriores ao encontro com conceitos ou teorias. Só depois o nome aos bois. Até mesmo porque realmente não tínhamos certeza de quase nada. Confiávamos uns nos outros, permitíamos e nos disponibilizávamos integralmente, mesmo quando antevíamos que uma proposta não parecia pertinente. Mas pagávamos pra ver, pra caminhar até onde desse. E se não era aquilo, paciência, sigamos de outro modo. Depois de algum tempo é que começávamos a ver que uma proposta de trabalho tinha a ver com o que se chamava de movimento autêntico, que uma outra tinha a ver com a eutonia, que o trato/ investigação com o peso, fluxo,tempo e espaço eram bases de estudo de Laban, de Bartenieff, enfim. O que atravessava-nos, meio ou totalmente híbrido, o que encontrávamos de teoria (Grotowski, Barba) ou 
trabalhos afins, como o do Lume, potencializava ainda mais o pensamento sobre o trabalho que se desenvolvia.

O senso de desorientação que vivenciamos no início do processo de trabalho com o Andanças, a experiência da exaustão, da assimetria, da respiração como condutor da dinâmica e plasticidade corporal, entre outros pontos de partidas incômodos, de certa forma, preparou terreno para que os dizeres, nossos e das referências citadas acima, parecessem fluidos e coadunassem uma certa inteireza do estar ali. De outra, parecíamos repetir 'formas' de encontro, como se essa imersão, e a maneira como tudo foi conduzido, levasse-nos a um encontro inevitável e consistente com uma forma e intensidades próximas àquelas experimentadas por Andréa Bardawil e Marília Bezerra, quando dos primeiros contatos com esses modos de ver (Teatro Pobre, Antropologia Teatral etc.).

\title{
2.1.1 - Do trabalho não-verbal. O silêncio como abertura, suspensão e conexão.
}

\author{
Março, 27/ 2012 \\ O veneno da delicadeza
}

Ontem, no Alpendre, um tempo de empatia atravessounos. Sutil, sem perguntas, nem respostas, sem maquiagens... um artifício desmistificado, desmembrado, solto e pulsante na própria imanência que é vida. Ar não rarefeito, plenos pulmões, intensidade calma... Integridade. "Importa quem fala?" Importa escutar. O silêncio abraça e tudo manifesta: quem, o quê, como.

O silêncio dá poder de 'verbo' a outras coisas. Menos/mais uma informação. Mais/menos uma privação. O silêncio como pausa cuja atividade potencializada seja a escuta. Ganhar os espaços, desacelerar e se predispor a contenção, que é retenção e emoção (movere). 
No período inicial da Cia. (quando entrei) e nos ensaios/pesquisa de movimento, foi-nos pedido que não conversássemos entre nós sobre o que fazíamos. Parecia estranho, mas caso houvesse uma real necessidade de falar, que isso fosse de forma escrita ou oral, mas entre cada um e as diretoras. E assim foi... pouco mais de um ano e o que estávamos fazendo ali? Claro, tinham os espetáculos, as aulas, as mostras, mas como mensurar o que fazíamos nos laboratórios? Como entender aquele caos? Por que fazia tanto sentido, se às vezes faltava nexo? A condição do não falar sobre, nem durante, nem antes, nem depois, para quê? Creio que a tensão e a contenção valeram a pena, não só como potência da fala e como dilatação do tempo, mas enquanto estratégia de criação e resguardo da atenção, da disponibilidade, do respeito pelo trabalho e pelos envolvidos. Tal parcialidade esburaca-se: "A falta de habilidade do grupo de construir a competência da reflexão sobre o nosso fazer entre nós (...) Eu acho que a gente não conseguiu passar saudavelmente pelo silêncio" (Angela, entrevista, 2011). Angela atina para uma certa reserva que foi cultivada, acredita ela, por esse silenciamento. Esse conversar/refletir crítico, na percepção que ela tem a partir do seu próprio não estar à vontade para expor-se, falar(-se), foi obliterado. Apesar dessa deficiência observada em decorrência de um hábito instaurado, e entendendo que coexistem perdas e ganhos nas escolhas feitas, não há como negar que tal estratégia potencializou a disciplina, o respeito, a ritualização das práticas. O que se desdobra a partir de uma convenção muitas vezes está além, aquém do pretendido. A reiteração estabelece uma sistematização, que alimenta e inculca um ponto de vista, mas o que se faz a partir daí, para onde se caminha, são outros quinhentos... No mais, constitui-se uma tentativa de vencer mais uma resistência, não só do verbo, mas também do julgamento, da autocrítica, da antecipação dos gestos, abertura de outros canais de comunicação, 
implicando outros estímulos e respostas. Uma estratégia que compunha aulas, ensaios, pensamentos.

Durante um bom tempo a acrobacia teve um lugar privilegiado enquanto aula e enquanto 'aquecimento' para ensaios ou pesquisa coreográfica/ de movimento/ de personagens. E nesses momentos o silêncio era condição indispensável. Nossa atenção professor e alunos - era redobrada e compartilhada. Outras coisas também não eram permitidas: ajeitar a roupa ou cabelos no meio de um exercício ou seq. acrobática; censurar (-se) ou rir (-se) quando o exercício não era 'bem feito' ou não terminado. A cada desatenção em relação a esses detalhes voltava-se a fazer o dito exercício, tantas vezes quantas fossem necessárias. Quem não estava fazendo a seq., ficava esperando, em posição ou postura de base, joelhos fletidos, abdômem conectado. Nada de conversas ou (auto) críticas. Aprender olhando, aprender fazendo, aprender experimentando. A imitação de gestos e movimentos não era a simples imitação de gestos e movimentos. Havia a demonstração do exercício executada pelo ministrante ou por algum aluno escolhido na hora, sem prévio acordo, mas que já detinha um conhecimento de certos códigos e estruturas usados. Cada um tinha de fazer e se responsabilizar por seu próprio itinerário. Quem 'puxava' a prática, quem ministrava, procurava dar condições para que se pudesse investigar o que se propunha. Imitávamos os movimentos (rolamento, estrela, ponte, paradas...), mas não era simples reprodução. A precisão vinha da atenção e da repetição, e era essa atenção que se buscava e se acentuava quando da utilização do silêncio. Quando não se entendia ou não se visualizava o exercício e sua intenção/composição, com um gesto era solicitado ao professor que ele repetisse. E assim acontecia.

Nas dinâmicas de exaustão, também se trabalhava na perspectiva do silêncio. Mas muitas vezes ele entrava depois, como um momento de suspensão para a agitação 
anterior desenvolvida com estímulo musical. A esse procedimento dávamos o nome de GUEM $^{33}$. É uma referência ao percussionista de cujas músicas também fazíamos uso. Depois, quando encontramos com o Lume, percebemos o treinamento energético como um similar dessa dinâmica, só que sem música. E o direcionamento que dávamos ia pelo viés técnico da dança e também pelos princípios da antropologia, que de uma forma ou de outro se tocavam - arquitetura de tensões, qualidade de movimento. Sobre esta última, Bardawil reflete:

O corpo precisa fluir um bom tempo, junto com sua energia, até conseguirmos identificar e reter a mecânica de um movimento mais interessante, junto com sua energia. (Esse "junto com sua energia", sempre, é que lasca, sabem os bons. É a isso que me refiro quando utilizo o termo "qualidade de movimento") (fragmento do texto Sobre coreografar..., 1998).

Moto-contínuo, retroalimentação. Exaurir 'para neutralizar o juízo de valor e alcançar uma camada mais fina de percepção e trabalho'. A sensação de ser engrenagem, movimento puro, desdobrável ao infinito. A sensação de se poder estar ali por horas a fio, sem parar, após ultrapassar vários sinais vermelhos, após ter negligenciado vários pedidos de socorro, após ter constatado 'agora sucumbo', pelos ares a poeira da minha pele... algo em mim se move e me move. Dialogando com o texto "O Corpo" de José Gil, Bardawil retoma a alegoria do corpo 'não-codificado', que pode ser acessado quando em estado de transe ou êxtase, ou seja, com a percepção alterada. Para ela, o ator-bailarino deve ter 'a consciência de seu alfabeto corporal, mas que também saiba encontrar esse corpo "não codificado"” (Andréa Bardawil, Arquivo pessoal, 18de julho de 2008).

\footnotetext{
${ }^{33}$ Referência (Título cd): GUEM. Musiques de transe. CDM (Le chant du monde), 1995-1997. Made in Germany.
} 


\subsubsection{Desconstrução e consciência corporal}

A imagem que me chega é a de uma criança a desmontar seu brinquedo, pra saber o que é que tem dentro. Uma manobra que desconstrói, desmonta, reparte, reagrupa, individua, articula. Às vezes, o brinquedo desmembrado não volta à sua unidade anterior, permanece desencaixado e outra coisa se dá a ver. É um procedimento que vasculha o detalhe, analisa. Mapeia, corre para as micropercepções, salientando-as, tornando ciente o micro que se dilui enquanto parte. Coreografar é uma forma de escrever, de clarear as idéias, justapô-las, organizá-las, dar-lhes um corpo, uma forma de apreender e dar a ver um sentido. É um reconstruir. Nesse interregno do explorar, improvisar e codificar, há a entrincheira das escolhas, da transmissão, das intenções. Abaixo, no depoimento, pontuamos um momento reflexivo sobre a pesquisa de movimento e de criação:

Um ponto desejável para se atingir: primeiro encontrar meu movimento, depois organizá-lo ordenadamente (coreografar); reproduzi-lo, então, repetidamente com as mesmas intenções, ensinálo a outras pessoas, e conseguir extraí-lo, com a mesma qualidade, de várias pessoas ao mesmo tempo. Quero experimentar isso. De que forma? Desconstrução contínua (objetivo: aumentar a consciência corporal e com isso a capacidade de minimização do movimento); Coreografar mais, reproduzir mais meus movimentos encontrados; Tempo de pesquisa e estudo para os bailarinos, contínuo e sistemático. (Objetivo: será que se eles estudarem corporalmente a mesma seqüência dias seguidos, amparados pelo trabalho de desconstrução, eles se tornaram mais ágeis na percepção e reprodução tanto do movimento exterior quanto do movimento interior?); Tempo de criação também sistemático (objetivo: muda algo no padrão de movimento e no processo criativo de cada um, todo esse trabalho sistemático e contínuo?)” ( Bardawil, textos para xerox, 1998 ).

Intenção e qualidade, reprodução e repetição, percepção, sistematização... uma busca de organicidade. Na intenção um ponto de confluência de detalhes: liderança de movimento, impulso, respiração e fluxo, 'acesso motor à emoção'. Movimento interior como algo que perdura para além da finitude do movimento exterior, de sua realização. 
Como encontrar e desarticular padrões de movimentos de cada intérprete, como agenciá-los num código vocabular transmitido?

Tais procedimentos e princípios de trabalho apontam primeiramente para a pessoalidade da Andréa: “encontrar meu movimento". Não é de uma forma, ou de um desenho de movimento, mas algo que é a sensação do movimento no seu corpo, que cartografias ele perfaz, que exigências, que silenciamentos, que clausuras, onde e como a (re)descoberta do prazer de dançar, mas que ter, ser um corpo. Encontrar aqui tem parecença com perder, destituir-se de "dramáticos efeitos" para embrenhar-se na atenção de si e do mundo. O "meu movimento", o "meu corpo" torna-se um desejo de vida, de ter tempo para criar-se, inventar-se, a despeito ou por atrito com as incongruências de legitimações e reconhecimentos de saberes e poderes. Encontrar um lugar de mobilidade, de respiro, de partilha. Ser atravessada pela força do encontro de cada pessoa com o seu movimento, seus recantos, seus "traços de humanidade". É no coletivo, no grupo que Bardawil pode potencializar o sentido de sua busca, pode olharse de fora, pode inteirar-se.

Algumas das particularidades do movimento de Bardawil são assinaladas por Angela, em sua monografia:

Sua condição física determina que seu trabalho corporal não seja de grande impacto, os pés precisam estar enraizados no chão, para o perfeito domínio do movimento e deslocamento. E, por conseqüência, nas suas coreografias e aulas os bailarinos e alunos ficavam mais no chão, sentados ou deitados, saindo e entrando no chão (levantando e voltando novamente para o chão), a mobilidade e o deslocamento são temas de experimentações em sala de aula. As aulas da Bardawil já estavam mudando antes disso, no entanto as informações do colégio de dança, no qual teve contado com técnicas corporais modernas e contemporâneas que tinham o "trabalho de chão" como base, e o novo problema de joelhos, marcam uma reelaboração de sua forma de trabalho corporal na dança. A improvisação também é outro tema que se reafirma em suas aulas, tomando um tempo muito maior nas aulas (ARAÚJO, 2006, p. 76). 
É preciso dizer que Andréa Bardawil era uma bailarina tecnicamente muito bem resolvida no jazz, sapateado, ministrando aulas e coreografando, assumindo posições de destaque na academia etc., por outro lado ela corrompia um ideal de corpo para a dança, pois sempre foi gorducha, com um peso acima do que era o padrão. Esse fator parece pequeno, mas a estética do corpo apto para a dança, o modelo que se buscava era algo mais 'balético', esguio. Além da sua própria compleição, havia o agravante da frouxidão ligamentar e as duas cirurgias que lhe renderam pausas nas atividades e parafusos nos joelhos.

O direito de dançar foi mais forte. Inventar sua dança era e é uma questão de sobrevivência. Reafirmar as escolhas, duvidá-las ordinariamente como um exercício espiritual. Entender seu movimento, desdobrá-lo, resgatá-lo, traí-lo. Decifrar seus mecanismos, saber de si para ir além. Bardawil vai traçando um caminho próprio, sempre de busca e de invenção de possíveis. Não sem quedas, perdas ou enganos, mas com permanente inteireza.

Aos demais componentes cabiam também muitos desafios. A escolha pela arte é algo visto com desconfiança, por conta da instabilidade financeira, nos mais das vezes, precária. Boa parte dos artistas da Cia., principalmente após as audições, formava um grupo de pessoas que não tinham uma situação econômica favorável, não eram "fillhos de academia", nem tinham pais abastados. Moravam na periferia de Fortaleza e se viam digladiados pelas necessidades prementes de ter dinheiro pra ônibus, pra alimentação etc. Encontrar esse movimento próprio era também uma forma de assumir o "direito de dançar", apesar de todas as dificuldades. O investimento de energia e o crédito que se dava à busca que se propunha, era uma aposta numa qualidade de vida que não cabia no enforcamento e ordenações dos imperativos cotidianos. Neste sentido encontrar o prazer do corpo no movimento e sua criação era uma atitude política, uma afirmação da vida. 


\section{2 - O entrelugar da experimentação}

Se de algum modo, hoje, o tema da experimentação é um clichê assumido, uma paragem obrigatória como sintomática de uma pulverização de idéias, conceitos, de outra feita, tal abordagem enquanto propositura estético-pedagógica pode ser refratária a usos e territórios banalizados no que concerne ao processo de criação.

Como aproveitar as fronteiras diluídas para explorar novos territórios, mas, sobretudo, para potencializar bons encontros que se configurem em novos acontecimentos, que por sua vez deixem rastros éticos em nossas experiências estéticas? (Bardawil, Tecido Afetivo, 2010, p.8).

Experimentar novas interlocuções como quem se despersonaliza em prol de uma escrita mais compartilhada, mais colaborativa. A diluição de fronteiras de níveis (quem sabe mais ou tem mais experiência), a aposta na mobilidade de funções e papéis assumidos, as trocas estimuladas, tangenciam algumas das características percebidas num processo colaborativo, de hierarquias amenizadas, de individualidades exacerbadas, de "lugares" relativizados, passear pelas funções (aluno, professor, coreógrafo, produtor, escritor) dá um gosto/ desgosto das responsabilidades assumidas e a depender de como se assimila, se articula e se preserva essa experiência, tal trânsito propicia um amadurecimento e respeito pela parte e pelo que parte do outro. E, numa retroalimentação, esse dado ou função, construído e apropriado, é relançado no caldo para que se forjem outros caminhos, procedimentos.

Uma habilidade de transitar num território de múltiplas entradas e saídas, de desdobramentos relacionais/ funcionais, e compor sua própria técnica/ método/ abordagem. Algo que exige um tempo dilatado - um aliado no processamento de informações e na criação metodológica. No diálogo com a Antropologia e as técnicas 
usadas na dança contemporânea, o Andanças talvez tenha vislumbrado uma dramaturgia/ pedagogia dos afetos ${ }^{34}$.

Tal e qual na cena, a construção de novas condições de possibilidade no campo da vida depende fundamentalmente da nossa habilidade em compor afetos (uma dramaturgia de forças), mais que traçar alianças (uma dramaturgia de formas), favorecendo o surgimento de um plano de consistência potente, subversivo em si e por si, atravessado por diferenças e dissensos, heterotopias, entre-lugares, estados de invenção que se constituem no avesso de um estado de exceção (Bardawil, Tecido Afetivo, 2010, p.7).

Na prática de experimentar, improvisar, de criar ambiências, a metodologia, o sistematizar, vem à tona, é uma das questões do/no modo como você opera com as coisas que você tem. Na experimentação você tem vários vetores e planos, que você configura e no qual se coloca dentro, imerso nesse processo de busca.

O aprendizado e o modo de fazer são da ordem da problematização, da experimentação, se o são da ordem da invenção.

La experiencia estética es lo que desestabiliza la percepción y la conciencia, y, al mismo tiempo, la materia con la que se las puede reconfigurar, si el sujeto se dispone a hacer algo con lo que le afecta. Una experiencia de formación se constituye de la disposición del sujeto a lidiar con lo que le afecta, con las fuerzas que alteran sus formas de percibir y entender las cosas. La formación concierne a una experiencia que une el acontecimiento y el ejercicio de la voluntad, lo irregular y la normalidad, la irrupción y el trabajo con lo que irrumpe (FARINA, 2005, p.10).

Ao tratar das relações entre arte e corpo, bem como da percepção e consciência potencializadas a partir da experiência estética, Farina acena para a problemática das mutações dos modos de sentir e perceber que embasam um pensamento sobre a prática artística e instigam a estruturação de uma pedagogia que dê conta ou que vislumbre a

\footnotetext{
34 “Una pedagogía de las afecciones buscaria favorecer prácticas de problematización y resistência a La homogeneización de los modos de vida, capaces de hacer ver y conducir lo paradójico, o irregular y lo heterogéneo que componen la realidad cotidiana del sujeto" FARINA, Cintia.(2005).
} 
complexidade artística contemporânea, assim cogita: "Una pedagogía de las afecciones tendría menos que ver con el orden de la enseñanza que con una práctica produtora de espacios de experimentación de lo cotidiano, y de los ámbitos de lo estético y de lo discursivo que lo constituyen". Não seria reafirmar um estado de oscilação ou fluidez de identidades, essências, mas criar ou experimentar na perspectiva desse contexto.

Andréa Bardawil, fazendo jus à função de diretora, impregnava-nos e conduzia bem a seu modo a Cia. Então, muitas situações e proposições partiam dela, às vezes mais permeáveis, às vezes mais impostas, seja por um senso de ordenação/ organização do grupo, seja por uma necessidade de seu percurso/ momento de pesquisa pessoal, via de regra uma reflexão partilhada:

Estou experimentando meu movimento. Vou passando por uma fase na qual me desnudo diária e disciplinadamente para mim mesma. Todos os dias, todos os minutos que posso, me contacto com meu movimento. E assim vou vencendo meu estranhamento, vou sendo mais forte que EU... Dentro desse momento, precisei me abster de estar formando corpos. (Antes, tenho que me permitir uma autodeformação.) (BARDAWIL, textos para xerox, 1998).

A experimentação do movimento, colocar o corpo em situação de estudo, passava não só pela Bardawil, mas pela Cia. de uma forma geral. Cada um com suas possibilidades e limitações, coreografando ou ruminando aulas, tencionava desdobrarse, observar-se, entender seu itinerário a partir também da escuta, da sistematização das práticas. E como fosse um caminho natural, os rituais particulares se iam construindo, contaminando. Chegar mais cedo ou sair mais tarde do que o horário marcado para suprir necessidade de alongamento, de centramento, preparando-se para um momento grupal. Dar-se um tempo diferente para a apreensão de uma determinada qualidade de movimentação, de sensação, sem distanciar-se demasiado de uma articulação coletiva. Transgredir propostas de exercícios ou atividades a fim de substanciar a pesquisa individual, sem, contudo, cair em um individualismo estéril. Convertemo-nos nós 
mesmos em campos de experimentação, mas até que ponto isso estava sendo criticamente incorporado? Até que ponto tais contaminações eram a reprodução de um discurso e a permanência num lugar "tranqüilo"?

Para o exercício da escuta, o cultivo do desapego e a economia de gestos. Alimentar-se do estranho, entender-se reviravoltando-se. Um momento difícil, incompreensível até, mas necessário. Abster-se de objetivações e precisões conhecidas, dar-se o gosto e o desgosto de confrontar a si própria. As aulas da Bardawil não eram mais porto seguro, careciam de referenciais tranqüilizadores, não sinalizavam certezas, expunham-se como ecos de um estado de transição.

Minhas aulas estão cada vez mais esquisitas, sem linha, sem lógica, sem intenção pré-determinada. Não penso muito nisso. É um momento pelo qual tenho que passar. E já esclareci para meus alunos: minhas aulas, atualmente não possuem qualquer preocupação com uma formação técnica. Quem entrar em sala comigo, espere qualquer coisa. Até mesmo só deitar no chão e ficar rolando pra lá e pra cá. Não tenho a menor idéia de onde isso vai dar, nem se é bom ou se é ruim. Simplesmente não tenho opção. E constantemente penso sobre isso, como é possível me sentir tão pouco à vontade hoje com uma metodologia que me serviu tão bem durante anos? Porque é incontestável que me serviu! Formei dezenas de bailarinas razoavelmente "limpas" tecnicamente, com todas as pernas e piruetas que tinham direito, e dentro do estilo da dança moderna e do jazz, ou seja, através de um sistema não tão fechado (e por isso mesmo com menos garantias de bons resultados) do que o clássico. (BARDAWIL apud ARAÚJO, 2006, p.63-64).

Habitar a experimentação seria a possibilidade de desenvolver habilidades/técnicas outras que não as já conhecidas, pondo em questão a universalidade de modelos? O não saber o que se está fazendo ou onde isso vai dar pode paralisar ou estimular ainda mais o desafio de procurar um nexo que não aquele vivido, algo com mais frescor e longe de uma reprodução mecânica.

Andréa caminha com o que cria, isso vai lhe movendo e deslocando seu ponto de vista acerca de seu próprio fazer. Entre o marulho do fogo e o crepitar das águas, ela vai criando seu sentido, permitindo fluir. 
Lembro que sempre gostei muito de ensinar, sempre achei que fazia isso muito bem, por isso conseguia tão bons resultados. E agora, hein? Sei não. Ainda gosto muito de ensinar... Duvido de tudo que sempre fiz (não do amor e da entrega, mas da forma, sempre e cada vez mais da forma). O interessante é esse ponto de vista: quando eu não questionava, quando apenas reproduzia uma metodologia de ensino que me havia sido repassada, conseguia excelentes resultados técnicos; agora que questiono, que não me cabe só reproduzir, me debato com a possibilidade de não mais conseguir qualquer resultado considerado desejável e até aceitável, dentro dos padrões da técnica. Aí é inevitável, cair na velha e já quase desgastada questão: importa tanto, mesmo, a tal da técnica? (Não deve ser uma questão suficientemente desgastada, já que ainda sinto tanta necessidade de retornar a ela.) (BARDAWIL, Arquivo pessoal, 1998).

Ao passo que Bardawil faz vacilar sua idéia de forma, também se questiona

sobre a 'tal da técnica'. Na verdade a tal da técnica refere-se a legitimação de uma técnica básica excludente e universal que responderia a todas demandas para se alcançar qualquer resultado técnico, formativo, estético. O processo criativo esburaca essa noção de completude, a partir do momento que padrões neuromusculares, que percepções diferenciadas são requeridas em virtude de articulações poéticas que delineiam estéticas ainda não formadas.

Me cansam as questões do tipo "quem nasceu primeiro, o ovo ou a galinha?", mas ainda não aprendi a dar-lhes o tempo exato de reflexão, sem exageros. É claro que penso nos meus alunos de hoje: será que tenho o direito de privar-lhes dessa técnica? Tenho. Não estou mentindo nem omitindo nada, falo sempre do que me acontece. Se eles ficam, optam conscientes. Por isso não me culpo. Além do que, tem outro ponto: os alunos de ontem tinham a técnica. Mas a maioria só tinha isso. Naquela época, talvez eu nunca tenha lhes dito que eles poderiam dançar sem ela. E talvez justo por isso a maioria tenha parado de dançar e ficado pelo meio do caminho, acreditando até hoje que não tem mais o direito de dançar porque não se é mais o melhor tecnicamente. (Bardawil, Arquivo Pessoal, 1998).

A dança enquanto criação não suporta esquadrinhamento, porque é de sua natureza mover-se, deslocar-se, ainda que sutilmente. E assim seduz, e assim aproxima, e pede interlocução e permanência para se corporificar. 


\section{3 - Da composição coreográfica}

Quero fazer, por agora, e neste contexto, algumas considerações sobre o processo de montagem do espetáculo Vagarezas e Súbitos Chegares, que foi gestado em 1999/ 2000, apresentado como espetáculo da Cia., e também como um dos resultados do curso de coreógrafos do Colégio de Dança. No depoimento abaixo visualizamos um pouco dos passos dados:

Escolhi corpos bem diferentes, porque também optei por construir essa diversidade cenicamente. Comecei por encontrar, partindo da dilatação corporal, os corpos dessas mulheres, seus jeitos, suas características e, por fim, o padrão de movimento de cada uma, matrizes, de onde partiriam a exploração cênica e sua codificação. A qualidade de movimento deve ser muito sutil. O caráter ritualístico na construção da cena persiste, como em todo o meu trabalho. E porque lidar com o corpo é um ritual. (BARDAWIL, Arquivo pessoal, 2000)

Através dessas palavras gostaria de salientar alguns aspectos que são preservados quando do pensamento sobre a construção da cena, a saber, o respeito e dilatação das diferenças, a busca de padrões e qualidades de movimento, o caráter ritualístico. Pormenores que alimentam uma visão de corpo e de mundo, e, mais especificamente, um entendimento de como trabalhar na verve e transbordo das potências de cada pessoa, de cada material, de cada propositura.

Tocar a delicadeza parece abrir uma brecha no tempo, uma suspensão na urgência das coisas. Quando pensamos na delicadeza, ela sempre vem associada a algo que é mínimo e lento, como se sua forma implicasse uma certa economia e não comportasse excessos ou, em outra perspectiva, algo cujo signo excessivo sempre aparece sob a forma de uma retenção extensiva com dilatação intensiva. Um pouco como a poeira, que suspensa, parece reter na névoa o tempo que sucede ao agito de uma superfície. Gestos mínimos atravessados por uma névoa de virtualidades que contra-efetuam no movimento dos corpos a pressa que a vida parece ter (Alexandre Veras ${ }^{35}$ - Folder $O$ Tempo da Delicadeza)

\footnotetext{
35 Alexandre Veras é fundador do Alpendre, é videomaker e interlocutor de Andréa Bardawil. Entre outras produções e parcerias, ele assina a feitura do videodança e da pesquisa de campo feita por ocasião desse espetáculo. Foi a partir dele que a Andréa veio a dialogar mais com conceitos filosóficos, como por exemplo os de Gilles Deleuze.
} 
Parto desse depoimento do Alexandre Veras, para iniciar um depoimento meu, que começa com o processo do Vagarezas e Súbitos Chegares e termina com o princípio de trabalho do Tempo da Delicadeza.

Lembro que o Vagarezas teve pelo menos duas versões. Numa delas eu abria o espetáculo com um solo. A criação deste solo partiu de uma exploração de partituras/movimentos lentos, muito lentos, quase desacelerados. Um contraponto ao meu lugar comum: era-me confortável a qualidade oposta. Enfim, foi um processo difícil, mas abriu uma brecha para pensar na possibilidade de um percurso que se dava nas transições, e não no movimento em si. Sem muitos arroubos creio ter tocado no delicado, e talvez isso tenha sugerido um caminho que desaguou na feitura da Delicadeza.

Depois de um instante de alongamento individual, começamos a exploração de amortecedores (encaixe e exploração das articulações no chão), de forma lenta e contínua, tornando precisas as oposições, evidenciando os caminhos. A partir daí tentamos codificar os movimentos, com deslocamento de um canto a outro da sala, usando a imagem da onda, que vai e vem, até chegar, como se a maré estivesse enchendo. Quando já codificados, os movimentos foram executados de uma forma mais dinâmica. Reinício da exploração dos amortecedores variando mais ainda a dinâmica (utilizando soltura e fluxo livre, depois contido etc.) e os planos (níveis) ${ }^{36}$. Depois resgatamos os mesmos impulsos em plano alto ${ }^{37}$. Diminuímos os movimentos, e continuamos a executá-los de frente para a janela, como se estivéssemos observando algo. No final, improvisação, tentando reunir todo o trabalho proposto. A movimentação lenta sempre é um problema pra mim. Fico angustiada porque me deparo com o blefe, o não acontecer fica mais evidente. Ou você sente ou não sente. Os caminhos se tornam difíceis. Quando se permite o fluxo, levar a energia de forma ininterrupta é maravilhoso, parece que uma coisa leva à outra. O problema é quando levo essa energia para onde ela não quer ir, e não sei como lidar com isso (Liliana Costa, Diário de Bordo do Tempo da Delicadeza, 03.07.2001)

\footnotetext{
${ }^{36}$ Parênteses meus. A utilização da palavra planos é equivocada. Refiro-me aos níveis espaciais em relação à proximidade com o solo (nível baixo, médio e alto).

${ }^{37}$ Idem.
} 
A transição como foco numa atitude desacelerada demandava uma 'quietude dinâmica' difícil de ser conquistada e fácil de ser perdida. Essa tensão expansiva e controlada me exigia a presença da respiração como forma de dissipar contrações desnecessárias advindas da contenção e da lentidão. O “juízo” corria agoniado como se quisesse escapar de um circuito fechado, opressivo ao meu lugar comum de movimentação: acelerado, rápido, compassado, sincopado. Incorporar um padrão no lugar de outro não é esquecer o que já está, mas dialogar conflituosamente com ele, daí o conflito, o drama estar no próprio corpo, em seus agenciamentos, em suas micropercepções.

Questões como textura, tempo e imagem vêm à tona. Num outro espetáculo, inspirado em Clarice Lispector, Bardawil enxuga a composição, minimizando o lugar da coreografia como habitualmente fazia, restringindo o uso do espaço, trabalhando-o com o mínimo de variações, com uma economia de deslocamentos. Isso lhe rendeu a possibilidade de focar sua atenção, e a dos bailarinos, num corpo dilatado, no minimalismo de gestos, numa repetição concisa, precisa e sutil. Mantém-se ainda a literatura como fonte de inspiração e conserva-se o palco à italiana. Andréa Bardawil observa:

Hoje, vendo, a Clarice ${ }^{38}$ marcou o assumir de um interesse por um outro universo estético de trabalho, que lidava com a composição coreográfica como um estado de pulsação. O Tempo da Delicadeza foi a culminância do que precisava ser sistematizado, que eu pude dessestematizar no Leonilson. (entrevista) ${ }^{39}$

Participei do início do processo de pesquisa e montagem do Tempo da Delicadeza.

O trabalho era desenvolvido em um outro horário (pela manhã) que não aquele em que

\footnotetext{
${ }^{38}$ Espetáculo A Dança de Clarice, apresentado no $1^{\circ}$ semestre de 1999 , como resultado coreográfico no Colégio de Dança do Ceará, no Theatro José de Alencar.

${ }^{39}$ Entrevista a mim concedida em 2005, por ocasião da pesquisa sobre o espetáculo Vagarezas e Súbitos Chegares..
} 
normalmente a Cia. se reunia (à noite). Minhas dificuldades de conciliar o trabalho externo com a programação dos ensaios, precipitou minha saída da Cia. Aliás, sublinhese, a saída de pelo menos metade do grupo. E assim foi. De uma média de dez pessoas, quatro assumiram até o final, junto com a Andréa Bardawil: Possidônio Montenegro, Andréa Sales, Noara Rodrigues e Evaldo Silva.

Bom, nesse pouco tempo que fiquei, percebi uma retomada dessa qualidade desacelerada, dessa vertigem, que um outro tempo dá aos movimentos, sejam eles gestos mínimos ou mais amplos. Fazíamos diário de bordo, pesquisa de campo, compúnhamos partituras ou motivos/temas de movimento. Por algum período, propositadamente, não tínhamos acesso ao registro audiovideográfico do material coletado nas viagens ao interior do Ceará. Esse momento de delicadeza era buscado à luz de nossa própria corporeidade. Coisas se gestavam, se descobriam, se assumiam:

Foi a partir do espetáculo O Tempo da Delicadeza, que a Andréa começou a botar a mão na massa do que ela queria de pesquisa corporal. No O Tempo da Paixão, a Andréa conseguiu formalizar mais técnicas, a partir do sensorial, do sentir o outro, isso que me emociona até hoje nesse espetáculo (Sâmia Bittencourt) ${ }^{40}$.

É interessante notar que essa experiência com o sensorial teve insights desde quando alguns membros da Cia. assistiram a apresentação do grupo Endança ${ }^{41}$, sob direção de Luís Mendonça, que posteriormente esteve ministrando oficinas e experimentos com o grupo, na época do SEST/SENAT, do Colégio de Dança, nos encontros coreográficos: "A gente passou uma semana na Taíba. Fazendo essas

\footnotetext{
${ }^{40}$ Entrevista concedida a Pedro Rocha (Jornal O Povo) por ocasião da comemoração do aniversário de 20 anos do Andanças e da apresentação do espetáculo $O$ Tempo da Paixão, numa exposição do trabalho do artista plástico José Leonilson, realizada de 17 de março a 29 de maio de 2011, no Itaú Cultural. In: http://www.opovo.com.br/app/opovo/vidaearte/2011/04/09/noticiavidaeartejornal,2123900/o-caminho-sefaz-andando.shtml

${ }^{41}$ Grupo brasiliense de dança contemporânea (1980-1996) criado por Luís Mendonça e Márcia Duarte, explorando práticas alternativas de treinamento (trabalho com o sensorial, gestos cotidianos, acaso etc.) e possibilidades corporais em espaços não convencionais. In: http://www.wikidanca.net/wiki/index.php/Grupo_EnDan\%C3\%A7a
} 
experimentações com ele. Ele experimentava aquelas coisas que ele fazia no final do Endança... do sensorial, né? Um jogo na areia com uma bola de meia... reflexo de movimento" (Samia Bittencourt, entrevista, 2011). Ou ainda nos dizeres de Clarice Lima:

Eu acho que o que a gente fez foi bastante viagem... sei lá, quando eu lembro da gente lá na Taíba improvisando, o Acleilton nu dançando, eu acho bem viagem... a gente foi lá pra minha casa... só que de uma certa forma fazia sentido... parece que tudo meio que fazia sentido dentro do que a gente tava vivendo naquele momento... pra mim tudo faz mais sentido agora, do que até quando eu tava imersa... com o Luís Mendonça a gente começou a pensar sensorialmente, né? e pra mim o Leonilson é só sensorial... tanto é que a primeira vez eu odiei, a segunda vez eu amei... porque a segunda vez eu me deixei levar... a primeira vez eu fiquei pensando e da segunda vez eu não quis pensar e amei, chorei... (Entrevista, 2011)

Bardawil e Isabel Botelho, intérprete-criadora da Cia., comentaram sobre o momento singular e de revelação que foi assistir ao espetáculo Animater, do Endança, quando de sua apresentação em Fortaleza-Ce. Arrebatador e delicado. Era aquilo. Um encontro que reverbera até hoje.

O mapeamento das sensações, ou das transições, e da percepção do outro como coautor da expressividade, abre um parêntese para se pensar na qualidade de recepção, não do espectador-público, mas da dimensão-espectador-ativador que se instaura quando da troca com um outro. E o que daí advém como possibilidade de construção técnica, poética, estética:

...sinto que uma nova fase se inaugura (no meu processo criativo e na própria Cia) com O Tempo da Delicadeza. Ali, o trabalho adquiriu um formato menos prazeroso para o público e mais estranho, digamos assim, porque comecei a investir mais na pesquisa com construção de imagens, através da dilatação do tempo e da utilização de gestos mínimos e cotidianos. A construção de algumas características estéticas começam a se afirmar. Mas tudo é começo, tudo ainda é muito experimentação. Em O Tempo da Paixão, começo a assumir minhas opções com mais propriedade, embora a construção coreográfica tenha partido mais da improvisação, do que dos elementos que usei no tempo da delicadeza. $\mathrm{O}$ universo plástico do 
leonilson já era muito forte, qualquer gesto a mais seria "dramático efeito". Mas já começo a ter mais claro a importância e o desafio que é a construção dramatúrgica de um trabalho, e de como isso se dá em relação. Os Tempos traz tudo isso de forma muito mais consciente. Me sinto muito feliz com esse trabalho (embora muitas pessoas achem que ele não impactante com o Tempo da Paixão ou mesmo Vagarezas). Mas é um trabalho completamente consciente nas suas escolhas, nu de todos os elementos, cru de feitos, preciso, potente na sua limpeza em carne viva, ainda que generoso e delicado. (B, $04 \mathrm{de}$ agosto de 2009) ${ }^{42}$.

É importante lembrar que o Tempo da Paixão teve duas montagens. Entre elas houve a criação d'Os Tempos. Para o vídeo-dança feito a partir dele, foi construído um mapa sensorial, que aqui exponho parcialmente, mostrando uma face da composição. Durante a montagem do espetáculo os intérpretes-criadores também fizeram, (d)escreveram seus percursos sensoriais, como mostra o diário de bordo de Sâmia Bittencourt, 12/março/2008):

"Descrição técnica dos percursos. Percurso 1.

Do alto, um abraço sustentado.

Desistir. Bacia que vai ao chão

e joelho que, de súbito bate

no chão.

Sem forças, respiro e o girar

da bacia me faz segredar

baixinho confissões bobas.

O girar é sempre idéia de um

recomeço.

Sento e reflito.

Impulsos respirosos.

Mãos ao chão como que buscando forças para voltar e

Volto.

Agora, de pé, palavras querem

Sair pelos dedos das mãos.

(Acompanhar a recuperação de um Bonsai morto)

\footnotetext{
${ }^{42}$ Trecho de correspondência entre mim e Andréa Bardawil, via e-mail, sobre o Tempo da Paixão.
} 
Os Tempos foi atravessado pela escrita e pela narrativa. Os intérpretes-criadores, além de fazerem seus respectivos diários de bordo, foram estimulados a criar histórias sob o tema da resignação. Tal procedimento fazia parte da tessitura da ambientação. O estabelecimento da prática de se escrever esse percurso sensorial (descrição técnica de percursos) também foi uma estratégia, até então pouco usual na Cia., que veio para sustentar essa outra proposta de pensar a coreografia, noutros parâmetros, pelas intensidades e encontros.

Lembro-me de ter assistido a alguns dos ensaios e de ter ficado surpresa com cada bailarino, particularmente com Samia Bittencourt, pela potência de sua partitura de movimentos e de sua presença. E creio que vislumbro nas palavras que descrevem seu Percurso I, uma similaridade com um processo seu de enraizamento e crescimento. No ensaio percebia-a desabrochar, vicejar com uma maturidade ainda não sentida. Denso e lascivo, pleno de delicadeza e de mortes. Sim, ainda buscava nuances, ainda se vasculhava, mas estava em casa, na companhia de outros catadores de tempos. 


\section{Os Tempos}

Uma história de encontros. O que um encontro pode provocar?

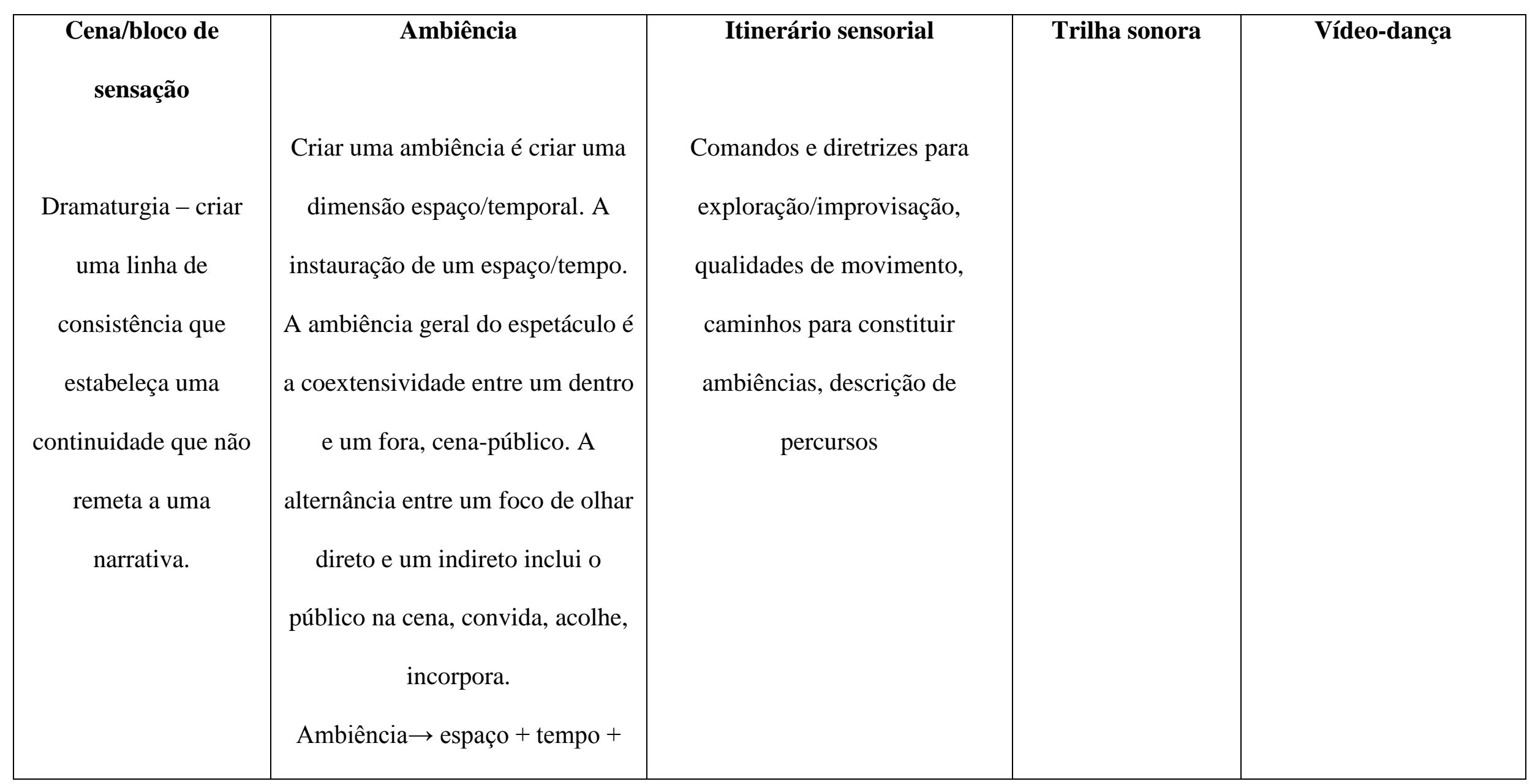




\begin{tabular}{|c|c|c|c|c|}
\hline & corporeidade & & & \\
\hline $\begin{array}{l}\text { 1. Caminhadas } \\
\text { (somos os que } \\
\text { andam) }\end{array}$ & $\begin{array}{l}\text { Preparação para o reconhecimento } \\
\text { do outro. O outro ainda é } \\
\text { anônimo. O primeiro encontro é } \\
\text { consigo mesmo. }\end{array}$ & $\begin{array}{l}\text { Caminhadas com foco indireto, } \\
\text { alternadas com pausas breves e } \\
\text { gestos sutis. Não há conexão } \\
\text { visual nem contato físico entre os } \\
\text { intérpretes, somente entre eles e } \\
\text { o público. O percurso foi } \\
\text { definido por cada intérprete, } \\
\text { tomando como referência a } \\
\text { escolha de cinco pontos distintos } \\
\text { pela sala, entre os quais se } \\
\text { deslocam, repetindo sempre a } \\
\text { mesma trajetória, indo e vindo. } \\
\text { Se cruzam mas não se }\end{array}$ & Moby piano 1 & $\begin{array}{l}\text { Primeiro, não vemos os } \\
\text { bailarinos em cena, é } \\
\text { como se víssemos } \\
\text { através dos olhos deles, o } \\
\text { que já foi e o porvir. } \\
\text { Aparecem vestígios do } \\
\text { outro, pegadas, sombras, } \\
\text { etc. } \\
\text { Foco nos olhares } \\
\text { Câmeras diferentes } \\
\text { (dispositivos na cabeça) } \\
\text { Talvez caminhadas em } \\
\text { vários lugares. }\end{array}$ \\
\hline
\end{tabular}




\begin{tabular}{|c|c|c|c|c|}
\hline & & encontram. & & \\
\hline
\end{tabular}




\begin{tabular}{|l|l|l|l|l|}
\hline 3. Solo Márcio & O quê ou quem se encontra? O & Solo construído pelo Márcio. A & Kathy’s Song & Lugar possível: no curral \\
encontro com o ingênuo, com a & partir daí, a proposta foi a & (Simon e \\
simplicidade (que não é & desconstrução de um fluxo & Garfunkel) \\
simplória). & contínuo, a execução do solo seca). \\
& buscando a independência entre & \\
& ução/gesto vale por si. & \\
\hline
\end{tabular}


Tal mapa, como podemos observar, traz tópicos que são recorrentes desde o espetáculo Vagarezas, como por exemplo: "o mais importante é a passagem de uma posição a outra", que nos reenvia também para o Tempo da Delicadeza no qual se contrapontuou os instantes privilegiados (p.ex., poses do balé clássico) e o lugar do entre como lugar das intensidades: "Antes de mais nada, a vontade por uma economia de gestos, um minimalismo que possa sugerir um minucioso mapeamento de tensões. Sutis alterações de energia, favorecendo a codificação do 'entre' uma forma e outra" (Bardawil, relatório d"O Tempo da Delicadeza - Bolsa Vitae - 2000/2001). O que se perde na valorização unilateral de 'posições chaves' é a potência mesmo que o movimento tem enquanto mudança, diferença e duração, algo da 'ordem do fluxo' que não está preso necessariamente à funcionalidade, causa e efeito.

“Os Tempos. Uma história de encontros. O que um encontro pode provocar?”. Reinventar na memória do agora a potência do encontro, do afetar e ser afetado. Tempos e instantes-já claricianos bifurcam zonas de conforto. O tempo não é cronológico, é empático. Um encontro, um tempo com tempo pro encontro. Tecer uma história que, fragmentada, expõe seus tempos de vazio e de plenitudes como entrelaçamentos e não como dicotomias. Esvaziar-se para dar e receber. Provocar pela resignação, pela espera, que não é só dor, nem só alegria, é um tempo pra viver o encontro, o próprio tempo. Tecê-los.

“Cena/bloco de sensação: dramaturgia - criar uma linha de consistência que estabeleça uma continuidade que não remeta a uma narrativa". Nesse primeiro momento em que se faz equivaler cena e bloco de sensação, antevemos uma propositura em quadros, ou melhor, em imagens. Cada cena parece reter uma imagem que se desdobra em outras, simultaneamente, sem um apelo linear mas em um continuum. Uma sensação não cabe em fronteiras definidas, seu início e seu fim não são visíveis, não a 
dimensionam. Ela é uma intensidade que habita. Por outro lado a idéia de bloco sugere compacidade, condensação: a imagem é um arranjo cinético-cinésico-cênico. A dramaturgia enquanto criação de uma linha - alinhave, que consiste, insiste: resistência, estabilização, coerência. Que daí uma narrativa não emerja, mas que a princípio remeta para a própria sensação.

"Criar uma ambiência é criar uma dimensão espaço/temporal". Instauração. Intervenção que manipula e esculpe o tempo-espaço. Uma fricção do tempo que é sensação no encontro consigo e com outrem. Abrir uma brecha nos padrões e circuitos perceptivos condicionados. "Ambiência $\rightarrow$ espaço + tempo + corporeidade". Construção na interação do corpo-pessoa com o entorno visual, rítmico, humoral. Relação que cria condições que criam relações. "Olhar: alternância entre foco direto e indireto". Dança de pontos e de vetores. O olhar que se deixa decifrar, que dá a ver o que persegue, o que elege, mas que também se faz travessia de distâncias, de lugares não ditos, alhures. Um jogo de sedução, uma relação de amor, uma brincadeira perversa.

Construção, troca e imanência. Um corpo que se faz na medida em que troca e que se compõe enquanto memória. Criando estratégias de 'neutralidade' para estar aberto a, adentra na sutileza do minimalismo e no emaranhado da desconstrução para preencher-se de vazio, e ser sempre uma outra coisa que se diferencia cada vez que se pessoaliza, sem no entanto enclausurar-se numa interioridade.

As explorações sensoriais acabam ou começam por criar no espaço/tempo laboratorial um fluxo de percepções que delineiam num só movimento, o jogo, o improviso e os desdobramentos dramatúrgicos. 


\subsection{Algumas poucas considerações}

As práticas de improvisação conduzem para um processo contínuo de escolhas, de mapeamentos de proposições, de verificação de possibilidades ainda não prescritas, do deslocamento de situações, de posicionamentos, da condição de imersão nas recorrências estéreis, em relação ao movimento, à percepção, à consciência corporal, aos parâmetros compositivos. Elas trazem uma pergunta que é cotidianamente viva: como estou hoje? Como percebo o outro? Como estar em relação? O que vem à tona de minha técnica, de minha leitura de mundo? Como respondo ao chamado do aqui e agora? Que microcomposições subsidiam minhas respostas, meus esclarecimentos, minhas dúvidas? Como me projeto e/ou me introjeto? Quais as ressonâncias dos diálogos?

A composição exige tempo de criação, articulação, edição, manipulação de materiais, dinâmicas, protocolos. Traz a importância de não só reagir, mas agir enquanto provocação, enquanto a contraparte do reativo, da causa e efeito.

Escuta e observação são conquistas, processos infindos que coexistem em todos os momentos de apreensão e transmissão de conteúdos, práticas, vivências. Elas calibram e afinam as escolhas, as necessidades, as apostas.

O Diário de bordo constitui um registro, um clareamento e concatenação de impressões, pensamentos e objetivos. Um exercício de exposição pelo verbo escrito e silencioso, um instante em que a memória se reinscreve.

Exercícios de criação coreográfica - experimentar formas de dizer e de fazer ver o que se diz. Um desenhar e redesenhar de intenções. Um dimensionar de impulsos para caber numa ex-pressão. Uma brincadeira comprometida com a manipulação de elementos representativos (mediadores) e presentativos (autorreferenciais). 
Pesquisa de movimento: exercícios de fragmentação (dos movimentos/ articulações), o trabalho com oposições (tensões, dinâmicas, ocupação espacial), a exploração do chão (apoios, amortecedores) entre outros, ativam a noção de corporeidade, de lapidação de gradientes de energia, da verificação das estagnações, da identificação de padrões neuromotores, do encontro/desencontros com as idiossincrasias.

O trabalho não verbal ao restringir e privar a fala, desperta a necessidade de outras disponibilidades, de fazer outros caminhos para a aprendizagem, que não passam pela explicação lingüística. De perceber certas dependências e submissões que temos às decifrações e indicações concedidas pela palavra. Saltam tentativas de aproximação, de ver a palavra no movimento, de ler pela palavra. O não-verbal diz da falha intenção universalista de leitura e codificação e expressão pelo movimento. Nem tudo passa pela sina do inteligível, o sensível apresenta outra lógica. O não verbal implica a restituição do lugar do silêncio e do silenciamento, tanto em relação ao verbo como em relação aos imperativos significantes na palavra que são desdobros de valores socioculturais construídos. 


\section{III - O Tempo da Paixão ou 'O Desejo é um Lago Azul'}

O tempo da paixão. Um tempo datado ou não, perene ou fugaz, um tempo que não o dos relógios, um tempo de tic-tac cardíaco, nervoso e abrupto e descompassado, um tempo de humores e rumores. Um tempo da paixão, que nasce, que ama-dura, que dói. Enquanto ruína, embevece ora pelo que resiste ora pelo que padece, pelo que cede, pelo que se esvai.

Um tempo de doação, da dor e do júbilo. Um tempo com paixão. Um tempo da relação, do compartilhar...

Pedras, cristais e objetos espalhados. Na ausência de cadeiras, o chão cru, a madeira nua. Uma disposição em arena. Os intérpretes e o público distribuídos nas extremidades da sala, arrodeando.

A materialidade e reverberação das coisas: texturas, densidades, sonoridades (vibrações), plasticidade, 'concretude'.

Os objetos também assistem, também se impõem, também prazer e dor.

Chão, tapete, cama, castigo, rebôlo, caminhos, instrumentos, carinhos, rudeza, tosquice, maleabilidade da pedra.

Barbaridade: o Tempo da Paixão podia ser o Tempo da Delicadeza que podia ser Os Tempos que podia ser..., e assim, indefinidamente.

Pedra

Cristal

Calça-jeans

Véus

Lençol

Saco de dormir

Pelúcia 
Mão de madeira

Travesseiro

Estar (ou ser) entre-com-sobre-sob pedra. A rudeza da pedra acaricia a alma, a pele.

Os vincos da pele na maciez da pedra.

A pedra nos rins, no sapato, no meio do caminho. 'Atire a primeira pedra aquele que não sofreu por amor'.

Pedra, grão, pedaço, solidez no chão. Bola de gude, bila.

As pedras como grãos de areia maiores. Os grãos como estrelas. O céu no chão. O céu é aqui.

Panos - eu sou o que me envolve.

O Tempo da Paixão ou o Desejo é um Lago Azul é um espetáculo cênico da Companhia da Arte Andanças, criado em 2004 e remontado em 2011. Inspirado na obra do artista plástico José Leonilson, tem direção de Andréa Bardawil Campos e atuação dos intérpretes-criadores Possidônio Montenegro, Samia Bittencourt, Tiago Ribeiro, Carlos Antônio dos Santos, na primeira versão, e Márcio Medeiros e Daniel Pizamiglio $^{43}$, na segunda, substituindo respectivamente Tiago e Possidônio. Algumas poucas palavras dos e sobre os intérpretes e as montagens:

Samia é a mais antiga do grupo, sua entrada, via audição, data de 1996. Em sua trajetória artística perpassam o mundo do circo (ela é palhaça e acrobata), da cultura popular (brincante/ pesquisadora), do teatro/ teatro de rua e da dança contemporânea:

Eu tive mais crises do que os meninos, porque eu era sozinha, mulher, assim... porque mulher, mulher... tem suas coisas... e eu tinha uma energia muito masculina e ela queria que eu diferenciasse isso dos meninos, se não ia ficar muito... eu tinha que ser mais curva, mais

\footnotetext{
${ }^{43}$ Assina a assistência de direção Acleilton Vicente; a concepção visual Enrico Rocha e Andréa Bardawil; Figurinos, Ruth Aragão, com a assistência de Gil Braga; iluminação, Walter Façanha; vídeo, Kiko Alves; Fotos, Paulo Amoreira, Tibico Brasil, Ivo Lopes,Daniela Millério e Bia Pontes;; Projeto gráfico Gaulciani Neves; apoio do Alpendre - Casa de Arte, Pesquisa e Produção.
} 
sensual, mais num sei o quê... que pra mim era um caos, eu não sou assim, até hoje eu não sou mulherzinha, entendeu? Mas ela queria essa energia mulherzinha, na cena. Acho que pra mim foi muito mais punk, porque eu me desnudei mesmo, sabe... e eu sentia também que a minha energia era muito a deles... ainda bem que eu sentia... é muito difícil, você ter o seu padrão, entender o seu padrão e modificar o seu padrão...

Possidônio foi aluno da Cia. durante um bom tempo antes de ser convidado pela diretora para participar do grupo. Tem passagem pelo balé clássico e formação em dança contemporânea e fisioterapia.

É como se a matéria-prima desse nosso encontro fosse a vida de cada um, com todas as suas alegrias e tristezas, amores e desamores, vida e morte... mas não é somente nosso. É de todos, é do mundo, sem deixar de tocar em coisas íntimas, pequenas e guardadas lá dentro, escondidinho... aonde nascem os desejos! $!^{44}$.

Tiago Ribeiro foi especialmente convidado para este espetáculo. É yogi e tem formação acadêmica em dança (UFBA).

O processo vem, cada vez mais, se afirmando depender da interação. Os momentos de isolamento são, na verdade, de percepção, e o objeto a ser recebido é externo. Pedras, panos, ursos, sâmias, carlos, possis, andréas, tiagos, são as influências transformadoras para se chegar a um momento leonilsiano ${ }^{45}$.

O Carlos tem formação em balé clássico, faz trabalhos solos, em videodança e dirige o grupo $n$ infinito, onde desenvolve trabalho de dança, teatro e performance. É o bailarino mais velho.

Até o momento o processo caminha para um tratado profilático, que previne e aguça os sentidos, que com o tempo tudo leva a crer num despertar de sensações íntimas: singular e similar. Um elenco perifericamente diferente, porém com a mesma capacidade e quantidade que nos iguala e nos faz viajar em sensações, o que dá uma idéia de ritual... um encontro com artistas pedrinhas, que tem um tempo mágico em ser pedra ${ }^{46}$.

\footnotetext{
${ }^{44}$ Fragmento do diário de bordo (setembro de 2004) de Possidônio Montenegro, extraído do folder do espetáculo.

${ }^{45}$ Diário de bordo, abril de 2004.

${ }^{46}$ Diário de bordo, março de 2004.
} 
Márcio Medeiros é ator, performer e bailarino. Participa do Teatro Máquina (de poética Brechtiana) e integra a Cia. da Arte Andanças, desde 2005:

Tinha aquela coisa de terminar o espetáculo arrasado, destruído, porque o espetáculo mexe muito com o emocional... e aí eu ficava dizendo assim: 'Meu Deus, eu não posso, isso é uma bobagem, como é que pode ?... essa coisa tá interferindo em mim e tal... Acho que hoje eu entendo mais e sei controlar mais isso. Eu sei chegar no espetáculo e sei até onde eu posso deixar que ele interfira em mim também... ${ }^{47}$ (Entrevista, 2011)

Daniel Pizamiglio é criador-intérprete, desenvolve trabalhos em performance e dança com mais dois artistas cearenses. Atualmente participa de uma residência com João Fiadeiro, em Portugal.

No início eu tive que desacelerar, pois tava muito ansioso por me mexer, por descobrir coisas ali, mas eu fui entendendo que eu tinha que escutar, não foi uma entrega de submissão, foi um estar com eles. (...)Tivemos uma reflexão sobre remontagem, como fazer, mas o que a gente pegou como escolha, que essa remontagem não seria essencialista 'vamos remontar o que a gente já fez'; a gente sabia que ia ter uma mudança... vamos potencializar essa mudança... ela até tentou reintroduzir novos objetos, ela pediu que trouxéssemos objetos que nos remetessem à infância, a nossa memória, a carinho, afeto amor, eles não ficaram. Foi uma tentativa.

A princípio, o espetáculo $O$ Tempo da Paixão trouxe-me questões acerca do trabalho do Andanças. Ele se configura tanto como continuidade quanto como uma ruptura, uma nebulosa que desfaz certos lugares comuns do modo de andar da Cia. Algumas particularidades tornam-no um recorte interessante para espreitar os vieses de outras proposituras na criação e nas técnicas utilizadas mas, por outro lado, algumas dificuldades vem à tona, como acompanhar o processo já reelaborado pelo tempo, não mais na dinâmica da sua feitura.

Quando assisti pela primeira vez ao espetáculo fui profundamente tocada. Foi a primeira montagem, de outras tantas, que não participei em absoluto. E apesar de um reconhecimento poético, tive uma sensação de estranheza. Esta composição furtou-me a

\footnotetext{
${ }^{47}$ Entrevista a mim concedida em 21 de novembro de 2011.
} 
identificação com as anteriores. O que tinha ali de mais ou de menos? Dois companheiros/ cúmplices de estrada, de trabalho, e mais outros dois que não tinham ainda tomado parte em trabalhos da Cia. Isso não era suficiente. A montagem me indicava, me sugeria que outros passos foram dados, que estruturas já sabidas, antes funcionais, foram abandonadas, mas nem todas.

A Barda fez isso, sempre experimentou isso: quero vocês dois... experimentem. Mas no fim terminava no 'sete oito', entendeu? Não terminava sem terminar, por exemplo, não terminava sem música... $\mathrm{E}$ o TD ainda tinha muita coisa coreografada, sabe? Talvez nem por ela, pelas meninas, mas tinha... o TP não tinha, era sensitivo demais, era sensorial demais, então se a gente perdesse a respiração não era aquilo... era muito doido e muito novo e muito bom fazer aquilo, porque ou a gente ia pra fazer de verdade ou não funcionava. Então a gente, todo dia de ensaio era um espetáculo... que a gente nunca ensaiava, não era ensaio... acabou-se esse negócio de vamos ensaiar, passa aqui, volta, limpa... limpa? Era outra coisa... ${ }^{48}$ (Sâmia, entrevista, 2011)

Em entrevista a mim concedida, para a monografia sobre o Vagarezas, em 2006, Bardawil afirma que "O Tempo da Delicadeza foi a culminância do que precisava ser sistematizado, que eu pude dessestematizar no Leonilson”. Condensando esse itinerário metodológico-criativo o referido espetáculo, ela observa e clarifica o percurso e o interesse na composição coreográfica enquanto estado de pulsação, que creio, será experimentado e assumido no Tempo da Paixão.

A concepção sonora dos espetáculos era feita sempre com muito apuro. No Tempo da Paixão, o apelo musical continuava. Mas o tônus da cena era outro. Menos quadrado, menos fechado, menos acertado, menos bonito, mais cru: "A trilha musical do Leonilson, do primeiro, foi quase que um rádio que cê vai passando com as músicas que a gente queria, do jeito que tinha o meu ursinho, o meu travesseiro, foi assim com as músicas, então foi juntando tudo de todos" (Sâmia, entrevista, 2011). O espetáculo de que falo, data de 2004/ 2005. Neste ano de 2011 conseguiram remontá-lo, depois de

\footnotetext{
${ }^{48}$ Entrevista a mim concedida em 19 de novembro de 2011.
} 
uma anterior tentativa vã em 2010. E aqui estou, tentando reelaborá-lo para vasculhar alguns de seus sentidos que acredito inaugurais.

O trabalho em questão não é uma comprovação de suspeitas, mas uma incisiva aposta na experimentação, anteparada pela pesquisa da Cia. e todas as influências que nortearam as práticas e montagens anteriores e posteriores. Digo assim porque no interregno da primeira e segunda versão muitas águas fluíram, muitas interlocuções, produções e encontros.

Entre Leonilson e Andanças e Deleuze e Clarice e Lygia Clark e... há algo da natureza do contágio. Cada um a sua maneira, encontra o sentido onde ele reverbera: no entre, esteja ele situado nos vãos das formas, das plasticidades, das palavras ou dos conceitos. No plano das ações essa compreensão de mundo se dá a ver nos modos de vida que habitam e se deixam habitar e que perpassam os processos e as obras. Também deles se desprende um silêncio que desafia os limites da linguagem, a indispõe. Um silêncio caro e cultivado. Uma pausa que não se confunde com inação, que não se confunde com falta, que é estratégia de sobrevivência, que é linha de fuga. Esse silêncio que sibila, que atrita, pois diz do pensamento o que ele ainda nem espreitava. Diz de uma outra forma de andar.

Leonilson, com sua materialidade artesanal, conceitual, provocativa, ambígua, íntima propõe uma exposição do particular que desliza para uma vida em comum, próxima, potente e fragilizada, uma espécie de território próprio que se compartilha e se expande na medida em que o outro que se avizinha é o esboço de um diálogo aberto e possível, seja ele perverso, irônico, leve ou brincante. Leonilson arma sob tecidos, cristais, desenhos, bordados a vida suspensa no desejo que é vida. A forma, as imagens, com um arranjo 'simples', tocam-nos justamente pelo que está entre: o dito e o não dito, 
ele e nós, a dor e a entrega. "Deleitar-se com cheiro forte de esterco"49, algo do infinitamente pessoal e intransferível que nos fere, nos transfere, constrange até.

Arte - plano de composição - figuras estéticas e sensações. Algo mais do que pura decifração, algo mais da natureza do contágio. O que força o pensamento/criação no processo de construção artística? Que elementos atravessam o modo de agir, entender, relacionar, ousar, reter? Quais capturas, quais fugas? Refletir como o pensamento se forma e não sobre o que já está dado como categoria, causa e efeito, resposta, efeito de sentido (procurado), mas justo o que lhe deforma, lhe desmascara, lhe revolve. A percepção em devir também se constitui para além do vivido, do subjetivo (individual), do pessoal. Quando os blocos de sensação são estruturados eles atingem uma autonomia, existindo como complexo de forças que atuam como atratores, levando artista, obra, espectador, para uma zona de indiscernibilidade, ou seja, um instante-já em que o identificável não está absoluto, o processo de vir-a-ser nunca chega a seu termo, sendo o devir um desterritorializar-se, um inflamar-se de micropercepções que não levam a nenhum ponto final, mas apenas criam e reverberam intensidades.

Clarice penetra na linguagem para, na aderência da palavra, escavar uma completa despersonalização, para constranger o sentido dado, para anunciar um estar artaudiano: "a sombra da flecha que não ocupa lugar no espaço":

Eu tenho a medida que designo - e este é o esplendor de se ter uma linguagem. Mas eu tenho muito mais à medida que não consigo designar. A realidade é a matéria-prima, a linguagem é o modo como vou buscá-la - e como não acho. Mas é do buscar e do não achar que nasce o que eu não conhecia, e que instantaneamente reconheço. A linguagem é meu esforço humano. Por destino tenho que ir buscar e por destino volto com as mãos vazias. Mas volto com o indizível. $\mathrm{O}$ indizível só me poderá ser dado através do fracasso de minha linguagem. Só quando falha a construção, é que obtenho o que ela não conseguiu. (LISPECTOR, 1998, p. 176).

\footnotetext{
${ }^{49}$ Trecho retirado do poema de Adélia Prado, Do Amor. PRADO, Adélia. Oráculos de maio. $4^{\text {a }}$ ed. São Paulo: Siciliano, 1999.
} 
Élida Tessler lembrou de texturas, cotidiano, detalhes... Lygia falou do caminhar sobre as pedras, do estado de arte sem arte, da escuta... Alexandre Veras sussurrou da poesia do vídeo, da imagem, da filosofia... como ele mesmo disse: "Conversa que gera obra que gera pensamento que gera...”. Entrelaçamentos e apoios e contrapontos: urdidura de possíveis.

Há exigências da composição da obra - o espetáculo $O$ Tempo da Paixão, que só se efetuam a partir da (de) composição do artista - "construção do corpo baseada na idiossincrasia, condicionamento por um efeito ritual ou terapêutico, livre associação de uso de tempo e de espaço" ${ }^{\circ 0}$, característica de evento, experimentação etc. O que deriva daí e o que vai à deriva pode ser pensado como criação de nuances semânticas e metodológicas, insurgência de apelos heterogêneos, modulados e diferenciais.

Para a montagem da primeira versão do espetáculo do Leonilson, a Cia. contava apenas coma Sâmia Bittencourt e Possidônio Montenegro como intérpretes-criadores, e então, Bardawil, para dar início à criação, convidou primeiramente o performer Carlos Antônio e, num segundo momento, o bailarino Tiago Freitas, que ministrava aula de yoga no Alpendre e que nutria então uma admiração pelo trabalho do referido artista plástico, aproximando-se ao tomar conhecimento da montagem em andamento através de Possidônio;

A gente fez um primeiro ensaio, eu, Sâmia e Carlos, sem o Tiago ainda. Nessa época eu tava fazendo umas aulas de balé clássico no SESC e encontrei o Tiago e por coincidência eu comentei que a gente tava montando um trabalho sobre o Leonilson, aí o Tiago disse: "eu não acredito, eu amo esse cara, eu tenho que falar com a Andréa, eu preciso me aproximar desse processo..." Eu sei que no segundo ensaio ele já tava. ${ }^{51}$

\footnotetext{
${ }^{50}$ Aspectos levantados no anteprojeto de pesquisa "Performance e efeitos V", de David Limaverde.

${ }^{51}$ Entrevista a mim concedida em 06 de dezembro de 2011.
} 
A integração de Tiago no 'elenco' do espetáculo dá pistas de como um outro sentido de composição estava impregnado no trabalho. Não compunham mais juntos os modelos de aproximação como estágio, ou audição, nada disso. A condição de estar, de permanecer, se dava pela potência do afeto, do afetar. Era esse o apelo, estéticodramatúrgico-pedagógico, que fortemente preenchia e criava a ambiência da invenção de si e do outro, do modo de fazer, no próprio movimento do deslocamento do olhar.

O primeiro ensaio que a gente fez foi sem as pedras ainda. E aí o Tiago veio junto com tudo e aí rapidamente a gente encontrou coisas muito legais. E a Andréa ficou super empolgada... e eu sei que o processo foi muito rápido, muito gostoso.

Eu acho que o Andanças tinha chegado num outro patamar, não sei, não sei se era influência também das pessoas de fora, se era um outro momento da própria Andréa, as coisas fluíram de uma forma mais tranqüila. Não foi fácil porque é um universo forte, né?... a obra do Leonilson, mas assim, foi muito tranqüilo mesmo, a gente encontrou as coisas muito rápido e depois teve só o trabalho de lapidar aquilo que a gente ia encontrando... mas a energia das pessoas era uma energia muito afim e foi realmente prazeroso, acho que a palavra é essa. E livre, a gente tinha uma liberdade que até pra mim que tinha uma pouca experiência ao tempo do Andanças sentia diferença. ${ }^{52}$

A questão da rapidez sugere a idéia de que o processo fluiu sem muitos entretantos, que o fato de se estar trabalhando, pela primeira vez, com pelo menos dois novos integrantes, não foi motivo que comprometesse essa fluidez, muito pelo contrário, foi um ingrediente precioso que dilatou esse 'livre fazer', essas aberturas a possibilidades inauditas.

No TP, a primeira versão, né, ela foi muito da gente se doar, porque ninguém... tinha nem expectativa assim, de alguma coisa, porque era tudo tão novo dançar com aquelas pessoas, e era tudo tão... tão na reverência, sabe... porque aquele negão, né? aí do lado um Tiago, que ele não anda, ele flutua, yogi total, principalmente naquela época, né? Então era muito louco compartilhar o espaço principalmente com aquelas duas criaturas ali. (...) A primeira coisa que a Barda começou a fazer foi, de fato, da gente experimentar: contato, num sei quê..., pra ela entender o que eram aqueles corpos, até porque eu também tava

\footnotetext{
${ }^{52}$ Idem referência anterior.
} 
muito distante e ela tinha que me ver também então... e eu ainda estou com todos os meus processos, ainda fechada, ensimesmada, em mim mesma, em mim, então foi muito doloroso por isso, porque eu ainda era muito, muito fechada, de não deixar meu movimento ganhar vida, de ter ainda muita vergonha, eu ainda era assim, né, muito crua e eu tive que me jogar porque senão era melhor eu sair fora, porque com aqueles meninos ali, todo coração... não tinha como... então eu me senti tão livre, tão leve com eles que a coisa foi super tranqüila, doída claro... ${ }^{53}$

Existia não só uma disponibilidade, mas um estado de presença que favorecia o afetar(se). Percebe-se que Andréa Bardawil também se abria e repensava, depois do condensado que foi o Tempo da Delicadeza, sua maneira de gerir um grupo, um trabalho, seu processo criativo com relação a todos os elementos que até então orientavam sua idéia de companhia, de processo, de espetáculo.

Tinha a possibilidade da gente, por exemplo, um dia que a Andréa sentisse que a gente não tava conseguindo engatar, da gente simplesmente sair e ir pra uma praia... E isso foi muito bacana. Até pela influência dos meninos serem de fora, de não terem a relação mais de companhia mesmo, coisa mais regrada, eu acho que tanto eles aprenderam com a Andréa como ela aprendeu com eles. A liberdade foi fundamental pra criação do trabalho ${ }^{54}$.

Pizamiglio também assinala que, durante o processo da segunda montagem, não houve uma autoavaliação entre eles, e que não se observavam em separado. O olhar externo era o da Andréa, e a prioridade era dinâmica do entre e não a construção individual. No depoimento do Tiago, extrato de seu diário de bordo, reforça-se tal pensamento:

O processo vem, cada vez mais, se afirmando depender da interação. Os momentos de isolamento são, na verdade, de percepção, o objeto a ser percebido é externo. Pedras, panos, ursos, sâmias, carlos, possis, andréias, tiagos, são as influências transformadoras para se chegar a um momento leonilsiano ${ }^{55}$

\footnotetext{
${ }^{53}$ Entrevista a mim concedida em 19 de novembro de 2011.

${ }^{54}$ Entrevista a mim concedida em 06 de dezembro de 2011.

${ }^{55}$ Diário de bordo, abril de 2004.
} 
Interior e exterior coexistem numa mesma superfície, que se distende quando dos contatos e dos afetos.

\section{1 - Do Processo criativo - conhecer em relação}

É inútil procurar encurtar caminho e querer começar já sabendo que a voz diz pouco, já começando por ser despessoal. Pois existe a trajetória, e a trajetória não é apenas um modo de ir. A trajetória somos nós mesmos. Em matéria de viver, nunca se pode chegar antes. (Clarice Lispector, A Paixão segundo G.H.)

Existe, no Leonilson, em suas obras e no espetáculo, uma dimensão autobiográfica que é pungente e ao mesmo tempo lança para o impessoal. Se é próximo, na mesma medida é alheio. Reforçando, pela abordagem que foi feita no espetáculo e pelas colocações de Bardawil o foco nas relações, sempre exteriores.

Para mim, a questão mais importante do trabalho de composição hoje, não é o tempo, apesar do tempo ser uma questão, porque eu o penso como sensação, como sensação eu preciso de dilatação do bloco de tempo, já que o trabalho é sensorial, mas o meu interesse tá na relação, na relação dos corpos, na relação das subjetividades, na relação dos campos de força ${ }^{56}$

Deflagra-se aqui a relação como o interesse anterior aos outros objetivos composicionais e dramatúrgicos que são desdobramentos desse fazer. O foco na relação talvez torne mais suave a questão das pessoalidades no sentido de que algo se processa no entre, um alheio composto e atravessado pelas cumplicidades, mas não saturado de uma autopercepção. Uma recursividade ao sensório e não ao sentimental.

A relação que se faz presente entre filosofia, vídeo e dança vem atravessando a percepção de Bardawil e fazendo-a investir objetivamente no que ela vai sentindo, vai nomeando, designando. Conceitos e modos de pensar que se redesenham e se

\footnotetext{
${ }^{56}$ Entrevista a mim concedida em 18 de novembro de 2011.
} 
referenciam. Clareamento de intenções. Interlocução com outros artistas, principalmente com o videomaker Alexandre Veras.

No processo de feitura do espetáculo houve muitas trocas, muitos desdobramentos, que se foram gestando e sendo mostradas durante e depois de findo o trabalho:

Quando a gente fez o Tempo da Paixão, a gente fez algumas mostras em processo, então as pessoas viam o processo e de alguma forma queriam chegar junto... essas propostas ${ }^{57}$ foram nascendo enquanto o trabalho tava nascendo também ${ }^{58}$.

Samia Bittencourt, ao falar sobre o término das apresentações da primeira montagem, disse ter ficado plena de coisas que tinham sido potencializadas e precisavam vazar, precisavam ser ditas, reelaboradas. Em virtude dessa pulsação, ela criou um solo intitulado "Daqueles que se sente saudade", resquícios do trabalho desenvolvido no Leonilson e que ainda impregnavam seu corpo.

\title{
3.2 - A Improvisação
}

\begin{abstract}
A improvisação poderia ser pensada como uma composição instantânea; na verdade, os grandes improvisadores são coreógrafos instantâneos, eles são capazes de estabelecer um universo de elementos, insistir neles, desdobrá-los, jogar com eles de maneira a estabelecer um princípio de composição que acaba sendo estético. (Paulo Caldas) ${ }^{59}$
\end{abstract}

A improvisação enquanto jogo que produz emaranhado de possibilidades, que estabelece um campo aberto para recorrências, ressignificando seus próprios parâmetros

\footnotetext{
${ }^{57}$ Intervenção de Paulo Amoreira (cartas de amor numa caixa, flashs do espetáculo e musica), filmagens e experimentação audiovisual de Ivo Lopes, fotos de Tibico Brasil, etc.

${ }^{58}$ Entrevista a mim concedida em 06 de dezembro de 2011.

${ }^{59}$ Esta e outras citações de Paulo Caldas, são oriundas de seu texto "O Corpo Qualquer", contido na apostila do grupo de estudos do Núcleo de Dança do Alpendre (março/ 2006). Caso haja citação proveniente de outra fonte, esta será citada.
} 
e dando a ver um princípio composicional, torna-se um agenciamento, em que fluxos de diversas naturezas são orquestrados e adensados num processo de incorporação.

Tal procedimento como estratégia de aula para abrir os canais da criação, bem como para compor coreograficamente, esteve constantemente entremeado na metodologia do trabalho do Andanças, alimentando o prazer de dançar mas também incomodando, visto que nesses momentos se expunha e se (auto)criticava o que se entendia por dança, que dança se fazia, de que forma o corpo se disponibilizava, como a pessoa se mostrava. Uma exposição que, a meu ver, colocava todos os participantes num mesmo barco, sem certezas dos caminhos, mas imersos num diálogo às vezes constrangedor, limitador, e por outro lado, libertador, agregador dos 'traços de humanidade', uma travessia conjunta entre 'pedras e travesseiros'. Coloca-se aqui um sentido da arte e da existência, resistindo e re-existindo (Paulo Oneto).

Com o passar dos anos e com a insistência do uso, a improvisação adquire maior contundência, ganha relevo, permanece. A “dança 7 e 8 "60 vai perdendo sentido, e a criação vai se dando não por uma reprodução de passos/ movimentos, mas por um vasculhar de energia e da lapidação desta numa forma estética mais autoral por parte dos intérpretes-criadores:

A gente conversava muito sobre o sensorial porque era uma coisa que regia o espetáculo, a energia que eu dou pra receber, então a gente precisava tornar isso palpável que era muito difícil, no começo foi muito difícil a gente entender isso... e era muito difícil quando ela falava assim: 'perderam, perderam', ora perderam... então era muito difícil no começo... como a gente tinha uma concentração muito forte também não era difícil achar de volta, resgatar. Era estranho, muito mais do que difícil era estranho, porque não tinha essa coisa do 7/8, era regido pela respiração, pelo sentir o outro, por isso que era tão verdadeiro... ${ }^{61}$

\footnotetext{
${ }^{60}$ Sequências de movimentos marcadas, uso de uníssono, correspondência linear com a música etc.

${ }^{61}$ Entrevista a mim concedida em 14 de novembro de 2011.
} 
Tratando pois de exigências outras, algo de natureza mais pessoal, autônoma, propositiva, problematizada. Algo no âmbito da criação mais descentralizado da mão da diretora.

Me anima estar em um trabalho onde a minha presença seja considerada, e as minhas opiniões, as minhas políticas e ideologias sejam acolhidas. (...) A minha presença e a do Márcio, mudou o trabalho, a Barda aceitou que ele precisava se manter em certas aspectos e em outros precisava mudar, os motivos que motivaram o trabalho permaneceram (Pizamiglio) ${ }^{62}$.

Quando Pizamiglio fala de sua presença podemos voltar a pensar naquilo que chamamos de diferencialidades lá no início de nosso texto, e que dizem respeito não só a uma estrutura física-técnica-artística, mas ao complexo que é o corpo como processo e a atitude diante do estado de coisas. $\mathrm{O}$ acolhimento e a abertura mencionada por Pizamiglio, dialogam com o processo improvisacional, na medida em que é exigido do intérprete-criador e do criador-intérprete uma responsabilidade e articulação diferentes, não é algo que pareça circunscrito às soluções estéticas, mas sim da ordem de atravessamentos do micropolítico, do ético, da coexistência de modos de vida. Um jogo de afirmações, confrontos, autonomias.

Atente-se que autonomia não é centralização e nem se confunde com autoria. Autonomia, suponho, é uma tal inteireza propositiva, mesmo que isso signifique silenciar, e onde quer que se manifeste dá um tônus singular à (encen)ação. Não é mais ou menos autônomo o artista que só interpreta, só representa, ou que cria ou que recria. A inteireza está na apropriação de um desejo, de um corpo, de uma persona, de uma poética. A inteireza é a impressão digital, mesmo que o verbo seja de outrem. Inteirezaandaime-ligadura.

\footnotetext{
${ }^{62}$ Entrevista a mim concedida em 22 de novembro de 2011.
} 
Atualmente Andréa procura não usar mais o termo presença, talvez pelo modismo ou pela grande e ampla possibilidade semântica que adquire, como observa Calado (2011) ao problematizar tal noção no contexto formativo do artista da cena, do atuante $^{63}$ :

(A presença) parece ter ganho relevância com as experimentações que desde a década de setenta do século passado invadem os palcos com elementos estranhos à representação: incursão do real, estética performativa, teatro pós-dramático, cena abstrata. (...) Tomando como referência a minha experiência pessoal, na qual a sensação de presença em cena está associada a um estado em que estou tão embrenhado na atividade que nada mais parece importar, não é apenas o choque entre a ficção e a realidade na cena que importa considerar: porque essa experiência depende largamente do período de trabalho que subjaz a apresentação, bem como do modo como este se inscreve num projeto artístico maior (p.10-11).

Como bem pondera Calado, em seu caso particular, a presença diz respeito ao seu estado de entrega, envolvimento e comprometimento naquilo que está a fazer. Um corpo em estado de fluxo que se manifesta de forma presente (aqui-e-agora), inteira e resoluta. Tocando na questão da experiência, do trabalho subjacente à cena e do plano geral artístico que lhe é imanente - uma construção reticulada e processual. E também da ordem do micro. Retomando algumas palavras de Paulo Caldas:

Eu diria que seria cada vez mais necessário pensar a improvisação como uma composição instantânea e ao mesmo tempo tentar pensar a composição como aberta à improvisação, mesmo que seja aquilo que eu poderia chamar de micro-improvisação. A micro-improvisação seria como um modo imediato de desconstruir e reconstruir uma partitura de movimento composta. Não se trata da diferença evidente entre as performances de ontem e de hoje. Mas de fazer da performance de hoje, agora, o lugar de atualização da lógica das forças (esforços) que promove o movimento. Estabelecer uma composição minimal no presente do movimento, recuperando, para a partitura composta, o estado de improvisação.

Estado de improvisação. Estado de arte. Estado de fluxo. Estado, presença, entrega e micro-resistência. Composição. Sensação, imagem, tempo.

${ }^{63}$ CALAdO, Alexandre Pieroni. Presenças. Tese - ECA - São Paulo, 2011- Orientador Antonio Januzelli 


\subsection{Blocos de sensação/ Pensando por imagens/ Dilatação do tempo}

A observação é o primeiro princípio da imagem

Tarkovski (1998).

Parto dessa afirmação que o cineasta Tarkovski coloca, entre muitas outras, em seu poético livro Esculpir o Tempo, para explanar sobre a composição que tem a imagem como discurso, conexão e desdobramento, não necessariamente nessa ordem. Uma imagem que é produzida e reverberada através da sensação e esta por sua vez pede, exige, se manifesta na duração e ritorn'ella imagens e sensações e...

Dançar é imprimir no corpo a sensação do movimento. Essa impressão só é possível se escuta e repetição estiverem presentes. Faço equivaler escuta e observação, como atitudes de imersão e jogo perceptivo. A observação/escuta enquanto primeiro princípio da imagem/pulsação.

Andréa Bardawil, em seu texto A Construção poética do visível: anotações para pensar uma dança/imagem, comenta: “Compor é ver e fazer ver. Um exercício que eu pratico decupado em instantes distintos, ainda que algumas vezes simultâneos: olhar, habitar, imaginar, inventar, dar a ver”. Um silêncio, uma coexistência, uma aventura, uma proposição, uma doação. Muitas nuances e matizes, porque cada uma dessas etapas é uma construção, são escolhas. Olhar e habitar pedem permanência, conhecer e reconhecer. Habitar é ganhar tempo para a afinação das escolhas, conscientes ou não. Habitar é imersão, relação mais contundente com o que o olhar capturou: "Viro devircoisa. Ocupo temporalidades extracotidianas" e ainda "A lentidão abre espaço para uma velocidade intensiva, que é diferente de aceleração", talvez um eco para "Como dilatar o tempo a partir do movimento?" 
“Imaginar: fantasiar, pensar, considerar. É quando percorro vários espaços e tempos simultâneos". Mover-se com, volver-se com as imagens, os significados, as abstrações, os atravessamentos.

“Inventar: criar. É quando escolho, elaboro, construo, configuro, instauro um novo campo de possível". Um momento em que o dar forma pode imprimir um outro olhar para os procedimentos, para conceitos e preconceitos, para modos operatórios. Um instante que são vários e que pedem concatenações, confrontações, uma lógica própria. Uma pesquisa coreográfica a várias mãos, que é contingência do encontro, que pode fugir do necessário para encontrar-se no lacunar, e aí forjar outros parâmetros, outros pontos de vista. Como observa Bardawil, ao tratar de algumas formas de se conceber a dança, quer numa coreografia previamente feita, quer sutilmente sugerida numa composição, transitar entre é uma (des)reterritorialização profícua:

Para alguns bailarinos, dançar é reencontrar lugares e formas demarcados previamente numa coreografia. Para outros, dançar é revisitar intensidades, temperaturas, ambiências sugeridas numa composição. Outros ainda, estes raríssimos, conseguem transitar bem por ambas as atitudes, pois entendem que uma não anula a outra, e que o trânsito permite que ampliemos nossa concepção do que é técnica, vocabulário, coreografia e dramaturgia ${ }^{64}$.

Trânsito, travessia, viagem. Experimentação, vivência, experiência. "Dar a ver: doar, produzir a percepção da imagem. É quando compartiho. E sou reconfigurada”. Como abrir uma brecha no lugar comum da corpoloqüência, da pretensão de dizer, de fazer sentir? Como a forma, em seu liame provisório, pode manter abertas as portas para que o silêncio diga, para que o hermetismo não o cale, para que as manobras sejam reveladoras e transformadoras de afetos alegres? "Como fazer da própria composição também uma experiência?"

\footnotetext{
${ }^{64}$ Texto extraído do artigo A Construção Poética do Visível.
} 


\section{4 - Montagem, remontagem - refazendo itinerários sensoriais/ ressignificando estruturas perceptivas}

Restabelecer uma coreografia/ partitura/ cena já dadas traz certas implicações e dificuldades provenientes de sua própria estrutura e da distância temporal e contextual em que ela se deu. No nosso caso particular podemos destacar, através da fala do intérprete Márcio Medeiros, alguns desses obstáculos:

Aí a gente começou a montar. Tinha o ritual de colocar as pedras e tal. Só que eu não tava preparado para fazer o espetáculo. Aí a Andréa Bardawil, dentro de várias circunstâncias, não só por mim, por outras pessoas que também não podiam na época, Bardawil desistiu de fazer. Aí eu me conformei, assim... nessa desistência, porque eu sabia que não ia dar conta... que tava sendo muito difícil, meu Deus do céu... eu tenho que fazer com que isso aqui seja meu, mas eu não consigo e tal... primeiro porque é muito difícil substituir alguém, você colocar no seu corpo aquilo que era de outra pessoa ${ }^{65}$.

Então, não só uma remontagem mas também uma substituição. Assumir e apropriar-se de algo que foi incorporado, tratado e moldado por outro corpo. Mas será que é só isso? Creio que não. Em uma coreografia mais 'formalizada', anteparada num acento musical ou numa contagem, quando uma rítmica a baliza e a inscreve enquanto desenho e pulso, a dificuldade é diferente e amainada, posto que as referências são mais variadas e as delimitações mais explícitas. No caso do Leonilson esses fatores estão minimizados, a coerência é sensorial, relacional. Isso também assinala, no olho de quem vê, de quem assiste, um outro processo de captura:

Quando eu assisti a primeira vez era muito desarrumado. Essas estruturas sensório-perceptivas eram muito sensórias pra eles. E aí eu sinto que com a necessidade que os meninos fizessem, eu vejo as coisas mais organizadas, mais limpas... pra mim, a sensação que eu tenho é que era um borrado. O primeiro Tempo da Paixão era um borrado, eu não conseguia decifrar, ver... E agora nesse outro momento eu visualizo as estruturas melhor... os jogos entre eles... ela ainda não abandona as músicas, mas de um outro jeito... abandona a

\footnotetext{
${ }^{65}$ Entrevista a mim concedida em 21 de novembro de 2011.
} 
iluminação, abandona o vídeo... e vai lá pra esse corpo que ela quer achar (Ángela Souza) ${ }^{66}$

Num primeiro movimento de remontagem e intuindo que não daria certo, fez-se a tentativa de se repassar ou se reproduzir o que já existia, isto é, o que o Possidônio havia criado seria realizado por Paulo José, bailarino que o substituiria. Malogrado êxito: "Eu entrava nas pedras com ele e ficava dizendo: 'esse momento era esse, essa seq. era assim', e era estranho, ficava muito esquisito, porque ficava falso. E ele encontrava um jeito lindo de fazer, mas não era aquilo, era um fake, tanto é que não funcionou" (Possidônio, entrevista, 2011). Também nessa mesma remontagem Márcio percebeu-se despreparado. Bardawil, naquele momento, desiste da remontagem. Márcio diz ter-se conformado, pois pra ele estava sendo muito difícil, tentar fazer que aquilo fosse dele, 'colocar no seu corpo aquilo que era de outra pessoa', no caso o Tiago.

No entanto, depois de ter participado d'Os Tempos, e com a perspectiva de remontagem por conta do convite feito para a apresentação na exposição do Leonilson, no Instituto Itaú Cultural, Márcio percebe-se preparado. Mas atentemos que não só ele. Na verdade, esse espetáculo dado no intervalo, Os Tempos, possibilitou o mapeamento sensorial, como ilustrado no fragmento de mapa anteriormente exposto. Tal escritura, tal reflexão, tal denominação funcionou como um anteparo para entendimento das intenções e modos de fazer/buscar/propor o que se queria e perceber melhor o que se configurava. Porém a experiência da montagem anterior é relativizada: "Eu tinha uma experiência com a Sâmia, mas quando eu fui pro Leonilson parecia que eu não conhecia ela mais, porque é outra coisa. E aí eu tive de reconhecer de novo" (entrevista, 2011). O que foi não era mais. Não havia a garantia de uma intimidade forjada no trabalho anterior. Se a pessoalidade é elemento de estranheza e de composição, suas mudanças e

\footnotetext{
${ }^{66}$ Entrevista a mim concedida em 17 de novembro de 2011.
} 
improbabilidades também o são. A pessoalidade não é um algo que caiba na cristalização de um conhecimento corporal e nem em um recôndito interior:

O Leonilson eu via que era uma introspecção, assim, eu tava ali vivendo aquela minha paixão, aquele meu amor, aquelas minhas coisas e tal, e de repente a Bardawil, em um determinado momento, ela diz: "olhe, eu quero que vocês amem o público também, eu quero que vocês dêem pro público". Acho que isso foi um diferencial do Leonilson passado para esse (Márcio Medeiros) ${ }^{67}$.

Esse olhar/dar para a platéia, dispersando o em si mesmo, impõe uma rearticulação da estratégia de sedução, de convencimento e expõe a fragilidade e vulnerabilidade de um estar compartilhado, provocando uma diferença de estados.

${ }^{67}$ Entrevista concedida em 21 de novembro de 2011. 


\title{
IV - Conclusão: técnica, criação e pessoalidade - vieses de uma composição dramatúrgico-pedagógica
}

\begin{abstract}
Acredito que como cada corpo traz impresso os cheiros, as cores e as formas que conheceu, por onde andou e habitou (e isso por si só já o reveste de "pessoalidades" de movimento, nem sempre consideradas e respeitadas pelo treinamento físico das técnicas de dança), assim também o olho de cada criador traz um registro próprio do tempo e do espaço, a partir do que experimentou. (Bardawil, fragmento de texto do projeto O tempo da Delicadeza)
\end{abstract}

Vou tomar de empréstimo um termo que Angela Souza usou em sua monografia ao se referir sobre o modo de ser da Cia., que ela denominou de cultura andante. Gosto da imagem que se projeta quando penso que o Andanças se trai no que cultiva e no que move a partir daquela já referida diferencialidade. E traição no sentido de traduzir-se constantemente com outros pares, no sentido de transcriar-se permanentemente pela intervenção das pessoalidades, dos deslocamentos, dos encontros.

Aparentemente, uma primeira diferença que se percebe entre o caminhar junto até e a partir do Tempo da Paixão, é esse novo feitio que ganham os encontros, os ensaios, as permissividades, as exigências, os desapegos. Se outrora "todos juntos vamos lá", fazendo as mesmas coisas juntos, equalizando e cobrando um mesmo tempo de estar, uma ideia de paridade na assimilação de uma regra de jogo mais estabilizada, previsível até certo ponto, no Tempo da Paixão isso é esgarçado. As pessoalidades parecem mais exacerbadas, no sentido de que é a partir delas, mas não só, que uma certa quebra de preconceitos se relativiza, percebendo-a não negativamente, não chegando nem a entendê-la como uma quebra de rotina, como falta, mas sim como um fato/ ato 'natural', coerente e 'necessário' nesse novo articular de vivências, experiências e experimentações. 
Partir de uma técnica codificada com um vocabulário instituído tem sido, tradicionalmente, o porto-seguro para processos técnico-formativos, onde se trabalha com um padrão motor organizado, de resultados visíveis e mensuráveis. No entanto, percebe-se que algo da ordem da experimentação e da experiência possibilita uma apropriação mais pessoalizada de tais códigos, permitindo a reflexão e ressignificação destes.

A técnica é um problema, mas é um problema que nos favorece. (...) A nossa técnica era o jeito que a gente se colocava no mundo, acho que foi por isso que ela nos escolheu. (...) Fazer trabalhos ligados às nossas motivações também é esclarecedor porque você vai se reconhecendo nas escolhas, fazer um trabalho pessoal que você utiliza as próprias mãos, você se reconhece naquilo que você produziu, e você se reconhece no outro. (...) A minha técnica sou eu. (Daniel Pizamiglio $)^{68}$

Interpretar, mexer, acrescentar, subtrair, imprimir, reconhecer-se como engrenagem na feitura e no feito da criação, problematizar a partir de seu ponto de vista, que sofre e é uma das muitas interferências, exacerba a individualidade ainda que esta se manifeste em relação e se transforme na interação. A pessoalidade não se fecha e não se consome no registro da intimidade, da projeção do ego, da familiaridade do reconhecimento, ela adere à criação para a si mesmo ser outra coisa. O jogo media o vínculo que se cria na interpessoalidade. Há uma manipulação, uma imposição daquilo que é desejado e doado, um jogo de concessões que acontece em virtude tanto de um olhar mais panorâmico quanto de uma percepção mais específica e localizada.

A gente ouvia muito o outro, sabe, o processo inteiro. A gente também achava que já podia tá pronto faz era tempo. Tinha esse incômodo com a lei do desapego, porque a gente se apegava em algumas coisas que pra gente era muito forte e pra Barda não, enquanto cena não. Então a gente tinha que estar a toda hora se desapegando. Isso, no processo, eu me lembro que foi muito ruim... que a gente não quer, é meu, eu que crio, então pr'eu negar agora é foda, eu não quero abrir mão disso daqui... eu me lembro que eu sofri... tinha uma cena lá que ela disse assim agora isso aí não me diz mais nada... que merda, porque pra mim ainda diz tanto... então você tem que se recolher e

\footnotetext{
${ }^{68}$ Entrevista concedida em 22 de novembro de 2011.
} 
pensar muito bem, porque... (...) Eu não tenho o olhar do todo e isso me confortava, entendeu? $\mathrm{O}$ "te vira" era usado várias vezes... te vira com teus desejos... (Sâmia Bittencourt) ${ }^{69}$

Recordo os dizeres de Alexandre Veras: "Experimentar outros corpos como expansão/dilatação do nosso. Outros corpos que revelem o quanto nosso corpo, já não tão nosso, é também um composto de intensidades que se redefine a cada encontro, a cada mistura, a cada contato"70. A princípio Pizamiglio e Sâmia sinalizam uma tensão própria das bifurcações do território da criação, que é o jogo de pegar e largar o que vai se construindo e desconstruindo. A ênfase novamente cai na relação que desapruma os quereres para recompô-los numa estética de forças.

O trabalho com o sensorial - já antevisto no encantamento sentido pelo encontro com o grupo Endança, já permeando as investigações e experimentações da Cia., e ainda reforçado com a investidura nas técnicas somáticas - irrompe o limite do possível, desbrava a potência do afeto, e, desta feita, contribui para a constituição de um tempo de aprender/desaprender sem equivalências, sem enquadramentos. Clarice Braga, exintegrante da Cia., reflete:

$\mathrm{Eu}$ acho que pensar todas as experiências que eu vivi, ou que foram vividas durante o Andanças e ver onde isso chegou, eu acho muito legal entendeu? Porque aí eu vejo uma proximidade muito próxima do discurso daquilo que ta em cena. Porque eu acho que talvez sempre foi uma busca por aquilo, só que ninguém sabia direito o que era isso, ou como chegava isso. Mas de uma certa forma quando eu avalio assim, de traz pra frente, pra mim faz muito sentido, faz muito sentido trabalhar risco da acrobacia, entendeu? Faz muito sentido trabalhar uma coisa que é completamente lúdica que é sapateado, faz muito sentido trabalhar aquelas coisas de teatro que a gente não sabe onde vai dar. ${ }^{71}$

Para isso uma permanência que não é ditada pela cronologia, mas pelo intensivo.

Uma permanência que se traduz em um estar junto para além de uma geografia. Um

\footnotetext{
${ }^{69}$ Entrevista concedida em 14 de novembro de 2011.

${ }^{70}$ Trecho do relatório final do Tempo da Delicadeza - Bolsa Vitae de Artes, 2001)

${ }^{71}$ Entrevista concedida em 27.12.2011.
} 
afeto que sintoniza desejo, acolhimento, despojamento, presença, existência. Invenção de si e do outro, como assinala Kastrup (2007), como emana Bardawil, como vêm incorporando o Andanças.

O outro sou eu. Está em mim. Cuidar de mim é preparar a casa para receber visita, a visita. É saber que aquilo que se experimenta não é posse de alguém. O corpo, a dança, a pessoa está para além dela mesma. Um fluir de micropercepções que, à revelia e sem muitos alardes, modifica o estado de coisas.

Sim, busca-se a intensidade dos encontros, mas não de forma direta. Há que desaprender, ritualizar, desprender-se da necessidade da expressão, reconhecer-se no outro.

A montagem e a encenação do Tempo da Paixão corroboram uma recorrência percebida e poetizada enquanto arte/vida: saber de si para saber dos outros, ou dito de outra forma, o trabalho sobre si mesmo; o foco no encontro e na relação, sempre redimensionado pela prática da técnica da improvisação e pela perspectiva do acontecimento; o mínimo, o detalhe, a delicadeza, percepcionados pela alteração de energia e desconstrução corporal; a sensualidade e diversidade da matéria; a textura da imagem; uma "ética da amizade" e uma "partilha do sensível” que ressignificam o estar junto e os valores subjacentes, reelaborando um sentido de grupo e de trabalho; a estranheza e a cumplicidade como formas de aproximação; o acolhimento do cotidiano/ entorno/ contexto sócio-cultural, como elemento interferente nas intenções que norteiam composição, aula, processos, modos de operar. Esses e outros fatores transversalizam a busca de uma metodologia enquanto invenção.

Mas há que se perceber que um caminho inventado é sempre um caminho construído e implica não só abrir-se ao acaso, às contingências, mas também encontrar 
uma forma. Aproximando-se, tal proposta metodológica, daquilo que Bonfitto (2008) apresenta enquanto tensão entre as noções de treinamento como práxis e como poiésis:

No caso do treinamento como práxis diferentes procedimentos seriam predeterminados e seus objetivos seriam estabelecidos de diversos modos: ele seria um meio que serviria a uma finalidade. No caso do treinamento como poiesis o objetivo mais importante seria aquele de criar as condições para que os materiais emerjam, para que eles possam vir à tona, os quais podem ser ulteriormente desenvolvidos pelos atores (BONFITTO, 38: 2008).

Nessa perspectiva, entre os processos de produção de significado e os de produção de sentido também haveria um conflito propositivo, posto que o sentido seria criado na articulação dos processos perceptivos do ator/bailarino com o material utilizado/manipulado na criação/ atuação; e o significado teria o anteparo de uma rede semântica e de recognição tanto para o performer quanto para o espectador, resvalando nos conceitos de representação e presentação.

A instabilidade dessa relação pode ser sentida desde os laboratórios, em que estão postos no plano da composição as iscas das fugas e dos condicionantes. A experimentação e a experiência dialogam no sentido de romper com as prisões ou com a demasiada soltura. Uma e outra se produzem num território de câmbios e trocas de informação, enfatizam significantes ressignificado-os, dando àquilo que se experimenta um lugar na construção de conhecimento, algo que se constitui enquanto experiência, que nos atravessa.

Aqui retomemos a relação entre técnica, criação e pessoalidade. Acredito seja uma negociação, assim, como num processo colaborativo. Enredados, tais campos, se despersonalizam mesmo se distinguindo. Atentar para a pessoalidade é perceber-se no âmago da criação. Entender a técnica ou as técnicas (de mover, de dança, de processos de criação), particularizadas pelo viés das propostas estéticas - híbridas, plurais e 
multiculturais, singularizando-se nas pessoalidades do movimento se estas ditas técnicas, codificadas ou não, são elas mesmas heterotopias, constituindo lugares de investigação de si e do mundo.

De que maneira a técnica, a criação e a pessoalidade podem compartilhar um lugar de estabilização, de bifurcação, de mobilidade, de diferencialidade? Entrando em contato e atravessando-se, ressignificando suas materialidades e relações, entoando processos e produtos híbridos? Seria uma possibilidade aventada na perspectiva de uma composição dramatúrgico-afetiva/ dramatúrgico-pedagógica?

A capacidade de afetar e se deixar afetar estaria no cerne dessa composição, em que se aprende e se desaprende como um ato de resistência, re-existência. 


\section{Referências bibliográficas}

AQUINO, Julio G. \& CORAZZA, Sandra M. (Orgs). Abecedário: educação da diferença. Campinas, SP: Papirus, 2009.

ARAÚJO, Angela S. Andanças: um inventário etnográfico do processo de incorporação de uma "qualidade de ser do corpo". Fortaleza: UFC, 2006.

(Monografia de Graduação em Ciências Sociais do Departamento de Ciências Sociais da Universidade Federal do Ceará).

BRAIT, Beth. (Org.) Bakhtin, dialogismo e construção de sentido. $2^{\mathrm{a}}$ ed. Campinas, SP: Editora da UNICAMP, 2005.

BURNIER, L.O. A arte do ator: da técnica à representação.Campinas: Unicamp, 2001.

CALDAS, Paulo. Um corpo qualquer. Rio de janeiro, 13p. (trabalho não publicado).

Texto anexo da apostila do grupo de estudos do núcleo de dança do Alpendre.

COSTA, Sylvio de Sousa Gadelha. Subjetividade e menor-idade: acompanhando o devir dos profissionais do social. São Paulo: Annablume; Fortaleza: Secretaria da Cultura e Desportos, 1998.

DANTAS, Mônica. O enigma do movimento. Porto Alegre: Ed. Universidade/UFRGS, 1999.

DELEUZE, Gilles; PARNET, Claire. Diálogos. Traducido por José Vázquez. Valencia, España: PRE-TEXTOS, 1980.

DELEUZE, Gilles. Conversações, 1972-1990. Tradução Peter Pál Pelbart. São Paulo: Ed.34, 1992.

. Mil platôs: capitalismo e esquizofrenia. Vol. 1. Tradução de Aurélio Guerra

Neto, Célia Pinto Costa. Rio de Janeiro: Ed. 34, 1995. (Coleção TRANS) 
Mil platôs: capitalismo e esquizofrenia. Vol. 3. Tradução de Aurélio Guerra

Neto et alii. Rio de Janeiro: Ed. 34, 1996. (Coleção TRANS).

EDUCAÇÃO \& SOCIEDADE. Revista de Ciência da Educação/ Centro de Estudos

Educação e Sociedade. Vol. 26, n.93, Campinas, SP: set/dez. 2005.

FARINA, Cynthia. Arte, cuerpo y subjetividad: estética de la formación y pedagogia de las afecciones. Barcelona. Septiembre del 2005. (Tesis Doctoral. Programa de Doctorado: "Educació i democràcia". Departamento de Teoria i História de l’Educació. Universitat de Barcelona).

FIORIN, José L. Introdução ao pensamento de Bakhtin. São Paulo: Ática, 2006.

FRITZEN, Celdon \& MOREIRA, Janine. (Orgs.). Educação e Arte: as linguagens artísticas na formação humana. Campinas, SP: Papirus, 2008. (Coleção Ágere).

GADELHA, Rosa Primo Cristina. A dança possível: as ligações do corpo numa cena. Fortaleza: Expressão Gráfica e Editora Ltda., 2006.

GALlO, Silvio. Deleuze \& a Educação. $2^{\mathrm{a}}$ ed. Belo Horizonte: Autêntica, 2008 (Pensadores \& Educação).

GUATTARRI, Félix. Caosmose: um novo paradigma estético. Tradução de Ana Lúcia de Oliveira e Lúcia Cláudia Leão. São Paulo: Ed. 34, 1992. (Coleção TRANS)

LAGNADO, Lisette. Leonilson: são tantas as verdades = so many are truths. São Paulo: Projeto Leonilson: SESI, 1995.

LEONARDELLI, Patrícia. Treinamento físico: diretrizes disciplinares para a autonomia criativa do ator. São Paulo, 2001 (Dissertação - Curso de PósGraduação em Artes Cênicas - Escola de Comunicação e Artes, Universidade de São Paulo).

LIBERATO, Mariana T. C. Experimentações: invenções de novos possíveis de existência no campo da dança cênica fortalezense. Fortaleza/ dezembro de 2004. 
(monografia de graduação no Curso de Psicologia da Universidade Federal do Ceará).

LISPECTOR, Clarice. A paixão segundo G.H. Rio de Janeiro: Rocco, 1998.

MARQUES, Isabel A. Ensino de dança hoje: textos e contextos. $2^{\mathrm{a}}$ ed. São Paulo: Cortez, 2001.

Dançando na escola. São Paulo: Cortez, 2003.

MOSTAFA, Solange Puntel. Vygotsky e Deleuze: um diálogo possível? Campinas, SP: Editora Alínea, 2008.

ONETO, Paulo D. "A que e como resistimos: Deleuze e as artes". In: LINS, Daniel (Org.). Nietzsche Deleuze: arte resistência. Simpósio Internacional de Filosofia 2004. Rio de Janeiro/ Fortaleza: Forense Universitária/ Fundação da Cultura, esporte e Turismo, 2007.

OSTROWER, Fayga. Criatividade e processos de criação. Petrópolis: Vozes, 1987. Acasos e criação artística. $2^{\mathrm{a}}$ ed. Rio de Janeiro: Campus, 1999.

PASCUAL, Jesus G. \& DIAS, Ana Maria I. Fragmentos: filosofia, sociologia, psicologia: o que isso interessa à educação? Fortaleza: Brasil Tropical, 2004 (Paradigmas epistemológicos e ensino, v.1). Fragmentos: filosofia, sociologia, psicologia: o que isso interessa à educação?

Fortaleza: Brasil Tropical, 2005 (Formação Pedagógica na Contemporaneidade, v.2).

PELBART, Peter Pál. A Nau do Tempo-rei: sete ensaios sobre o tempo da loucura. RJ: Imago, 1993.

POURTOIS, Jean-Pierre \& DESMET, Huguette. A educação pós-moderna. Tradução Yvone Maria de Campos Teixeira da Silva. São Paulo: Ed. Loyola, 1999. 
RAMPAZZO, Lino. Metodologia científica para alunos do curso de graduação e pósgraduação. São Paulo: Loyola, 2002.

RODRIGUES, Graziela. Bailarino - pesquisador - intérprete: processo de formação. Rio de Janeiro: Funarte, 1997.

SALLES, Cecília A. Gesto inacabado: processo de criação artística. $3^{\text {a }}$ ed. São Paulo: FAPESP: Annablume, 2004.

Redes da criação: construção da obra de arte. $2^{\mathrm{a}}$ ed. Vinhedo, SP: Ed. Horizonte, 2008.

Arquivos de criação: arte e curadoria. Vinhedo, SP: Ed. Horizonte, 2010.

STRAZZACAPPA, Márcia. "O corpo e suas representações: as técnicas de educação somática na preparação do artista cênico”. In: STRAZZACAPPA, Márcia \& MORANDI, Carla. Entre a arte e a docência: a formação do artista da dança. Campinas, SP: Papirus, 2006. (Coleção Ágere).

TARKOVSKI, Andrei. Esculpir o tempo. Tradução de Jefferson Luiz Camargo. São Paulo: Martins Fontes, 1998.

ZOURABICHVILI, François. O vocabulário de Deleuze. Tradução André Telles. Rio de Janeiro: Relume-Dumará, 2004.

Blogs e Sites

http://doquesepodedizer.blogspot.com.br/

http://grupodeestudodancalpendre.blogspot.com.br/

http://ciadaarteandancas.wordpress.com/

http://www.projetoleonilson.com.br/site.php

http://tecidoafetivo.com/ 
ANEXOS 
ANEXO A - Das entrevistas...

A opção por uma entrevista semidirigida, privilegiando a descrição dos processos, pautou-se pelo seguinte roteiro:

Momento Um - A trajetória artística pessoal;

Momento Dois - Os primeiros contatos e a experiência com/no Andanças;

Momento Três - Considerações sobre e/ou descrição do processo de montagem/apresentação do espetáculo $O$ Tempo da Paixão ou 'O Desejo é um Lago Azul';

Momento Quatro - Reflexões sobre a relação entre técnica, criação e pessoalidade. 
ANEXO B - Reprodução de fotos de alguns espetáculos e respectivos textos que acompanhavam material gráfico. 


\section{Vagarezas e súbitos chegares...*}

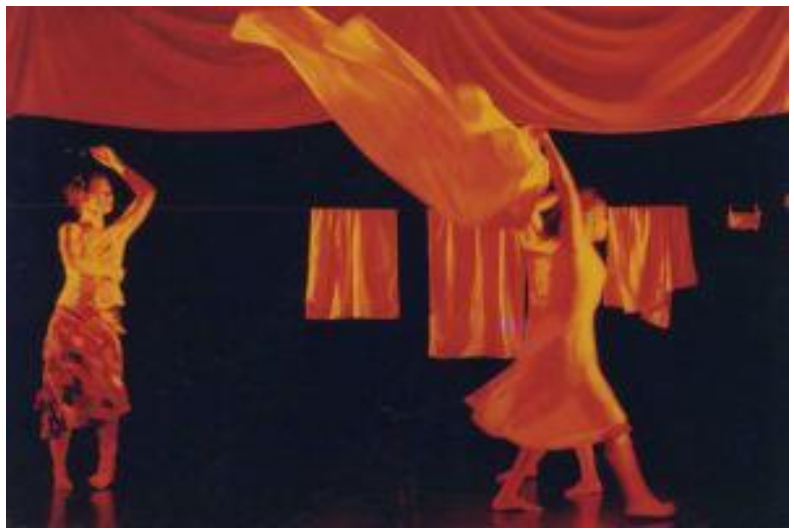

Todas as Fotos são de Tibico Brasil

Vagarezas e Súbitos Chegares é a tentativa de contar um pouco sobre o universo feminino, sugerido nas obras da escritora mineira Adélia Prado e da artista plástica gaúcha Elida Tessler. Em Adélia, as mulheres são sábias, mulheres para quem não são escassos os momentos de doçura, para quem a latência no corpo - a vida ardendo tranqüila - não lembra só os caminhos recusados e amargamente perdidos, e sim todos os próximos. No trabalho de Élida, os objetos do cotidiano são a principal matéria prima: coadores de café, lençóis, toalhas, bacias. Objetos diários expostos nus, e a força quase cruel da violação do branco. Os dois trabalhos remetem à fé e ao prazer. Mulheres que tecem panos e vidas, férteis.

\section{* Livremente inspirado nas obras de Adélia Prado e de Élida Tessler}

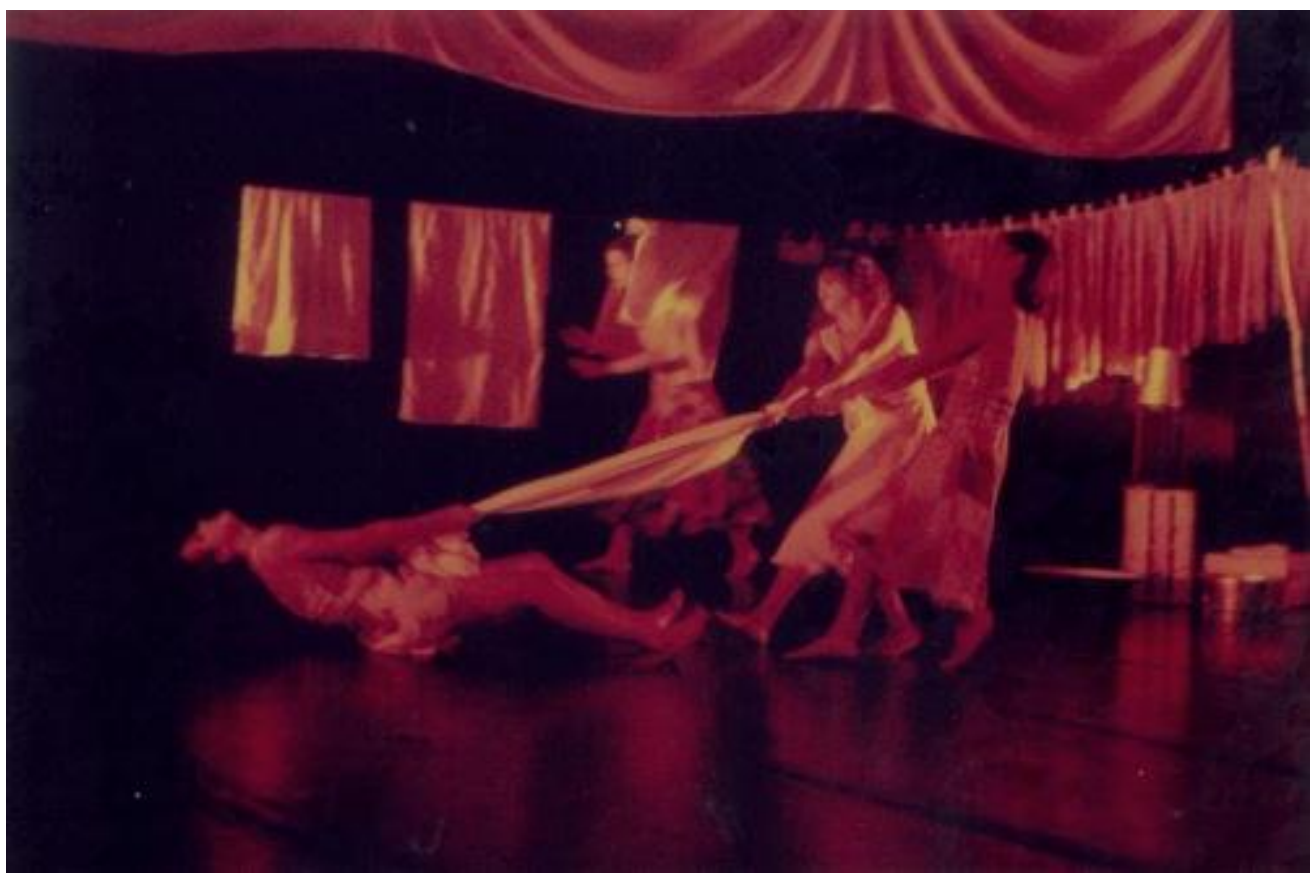




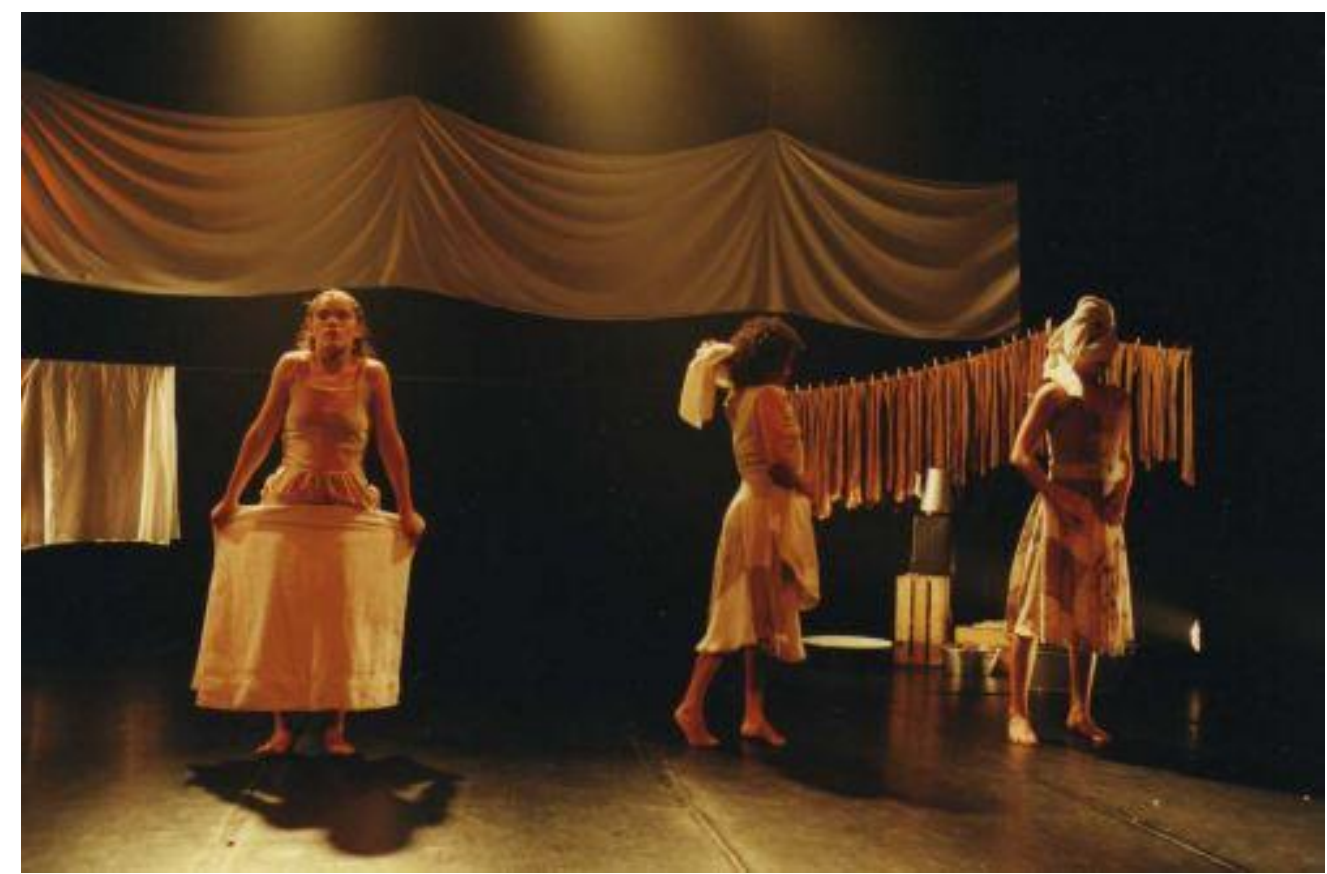

\section{Ficha Técnica}

Concepção, Direção e Composição Coreográfica: Andréa Bardawil

Intérpretes-criadoras: Clarice Braga, Isabel Botelho, Liliana Costa e Rosana Mara Música: Bobby Mcferrin, João Gilberto e Yo Yo Ma

Poesias e voz: Adélia Prado

Iluminação: Paulo Cesar Medeiros

Operação de Luz: Carlos Benevides

Concepção Visual/Cenário: Elida Tessler

Figurino: Vanessa Damasceno

Projeto Gráfico: Eduardo Dias

Fotos: Tibico Brasil

Video: Alexandre Veras

Extraído de: http://ciadaarteandancas.wordpress.com/repertorio/vagarezas-e-subitoschegares/ 


\section{$\underline{\text { O Tempo da Delicadeza }}$}

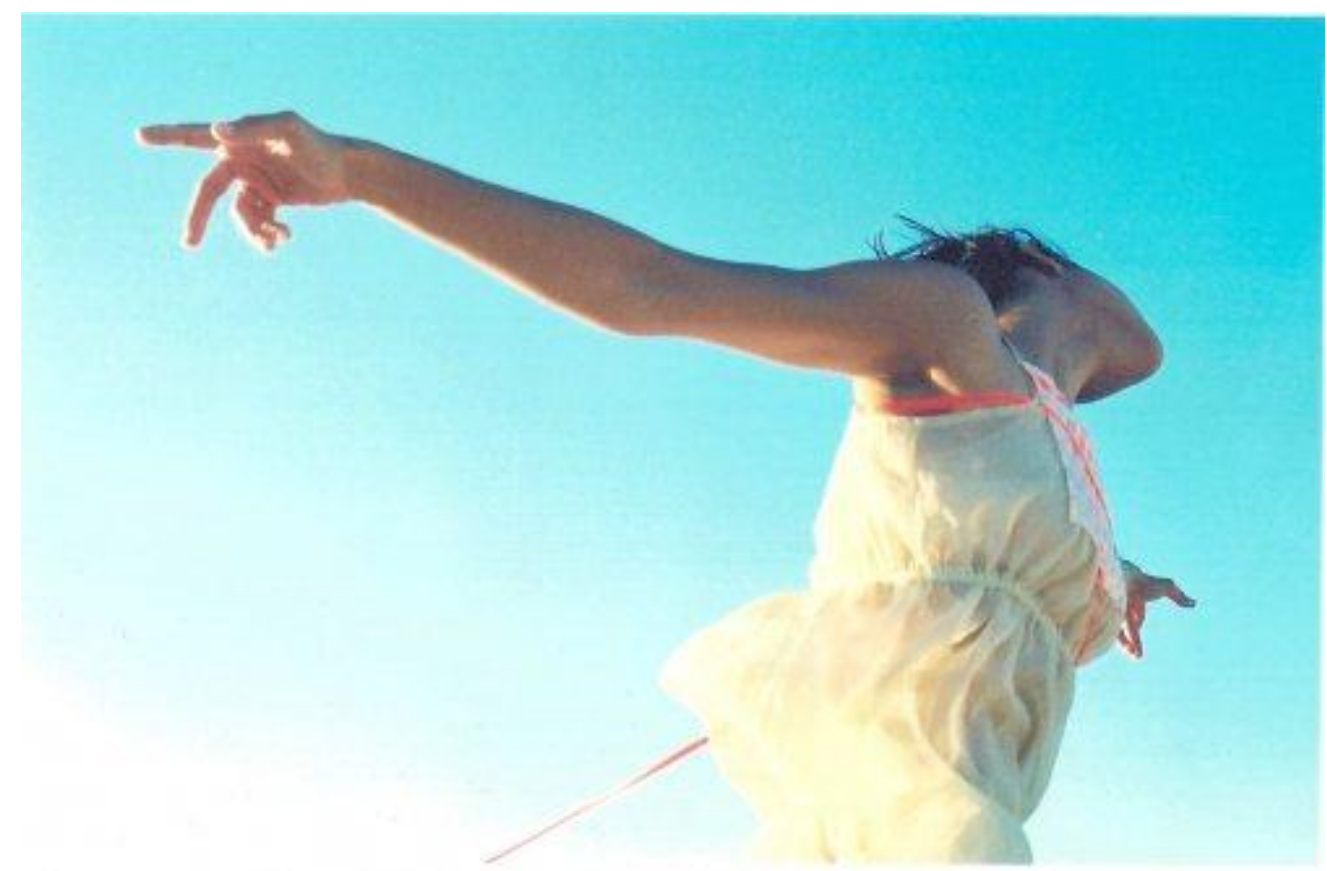

Este projeto foi inicialmente apresentado à Bolsa Vitae de Artes pela coreógrafa Andréa Bardawil, em 2000, e propunha a realização de uma mesma pesquisa estética unindo duas linguagens, o vídeo e a dança. O projeto foi realizado em parceria com o vídeomaker Alexandre Veras, e teve como resultado dois produtos distintos: o espetáculo e o vídeo-dança.

Existem pessoas que sobrevivem à vida e, em alguns casos, à dor, de uma forma tão resignada, que mais parecem envoltos num manto de delicadeza, onde o tempo é próprio, composto de um olhar calado e profundo, que às vezes não é alegre nem triste, mas que é só espera. Deserto que não é vazio nem estéril, é cheio e potente, solidão povoada. A lentidão abre espaço para uma velocidade intensiva.

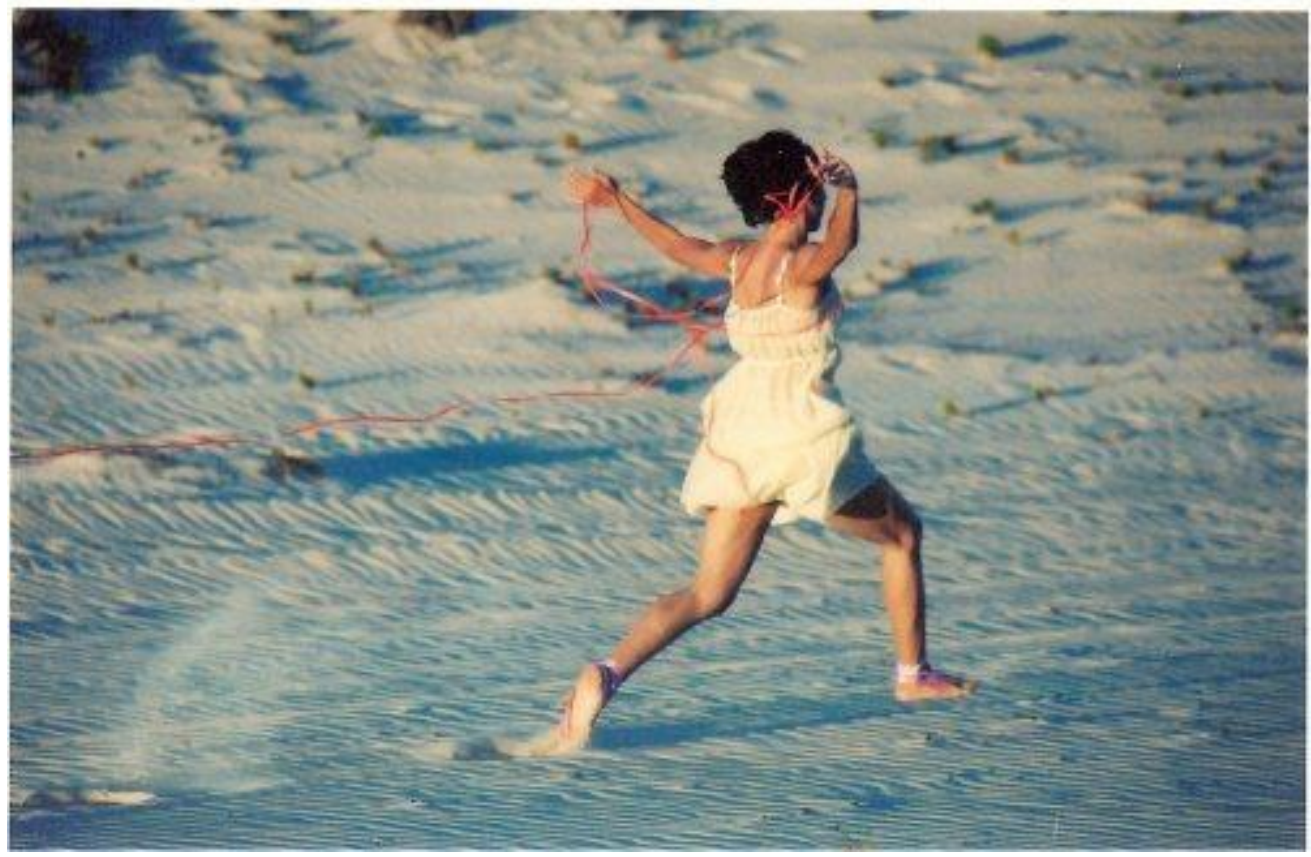

Todas as Fotos são de Daniela Millério 
Gestos mínimos, movimentos econômicos. Silêncio. Velocidade é diferente de aceleração. O Tempo, sempre. O Tempo que se inscreve no rural e no urbano. O Tempo inscrito em cada corpo. Espera, contemplação, resignação, sobriedade, tantas impressões podem caber numa só: delicadeza.

A velocidade surge, então, como uma dimensão além da aceleração. Como um regime de disponibilidade onde pode colocar-se um corpo, independente de sua localização geográfica, uma possibilidade de construção de uma linha de fuga. Um tempo intensivo, potencializador dos encontros e dos afetos.

Nas viagens, exercício de recolhimento, o que mais se inscreveu em nossos corpos foi a desaceleração e o silêncio. Observar não deixa de ser um exercício de despojamento. Deixa-nos de frente para a impossibilidade da linguagem. Vontade de não dizer mais nada, apenas provocar um deslocamento de olhar.

O que gostaríamos, então: provocar, no olho que vê e no corpo que presencia, uma desaceleração, uma suspensão de tempo, um silêncio, e que ele vibre onde encontrar qualquer possível. Que se construa no meio, no entre a forma, tentativa mesma de resguardar-se dos excessos.

Andréa Bardawil

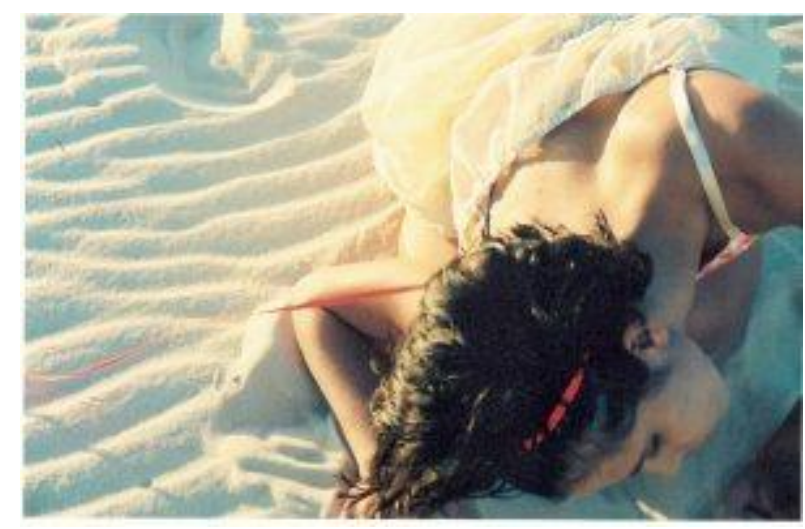

Tocar a delicadeza parece abrir uma brecha no tempo, uma suspensão na urgência das coisas. Quando pensamos na delicadeza, ela sempre vem associada a algo que é mínimo e lento, como se sua forma implicasse uma certa economia e não comportasse excessos ou, em outra perspectiva, algo cujo signo excessivo sempre aparece sob a forma de uma retenção extensiva com dilatação intensiva. Um pouco como a poeira, que suspensa, parece reter na névoa o tempo que sucede ao agito de uma superfície. Gestos mínimos atravessados por uma névoa de virtualidades que contra-efetuam no movimento dos corpos a pressa que a vida parece ter.

Alexandre Veras 


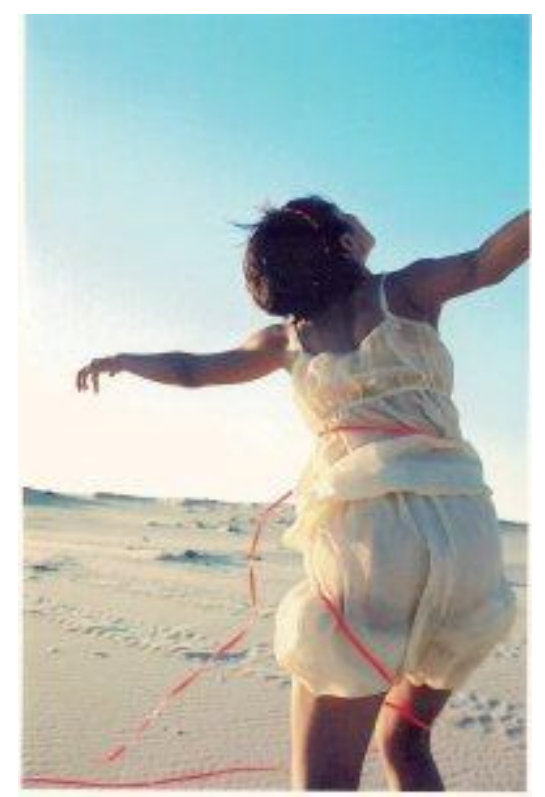

\section{Ficha Técnica}

Direção e Composição coreográfica: Andréa Bardawil

Intérpretes-criadores: Andréa Sales, Evaldo Silva, Noara Rodrigues, Possidônio Teles. Direção de Vídeo: Alexandre Veras

Edição: Alexandre Veras

Câmera: Alexandre Veras, Glauber Filho

Produção: Márcia Sucupira

Assessoria de Comunicação: Thaís Andrade

Figurino: Ruth Aragão

Assistente de Figurino: Gil

Cenário: Gustavo Adolfo

Iluminação: Alexandre malta

Operação de Luz: Fernando Peixoto

Operação de Vídeo: Raimundo Nonato

Projeto Gráfico: Galciani Neves

Fotos: Daniela Millério

Arranjos para "Assum Preto": Moacir Bedê e Rian senise

Composição de "O Tempo da Delicadeza"/trilha original: Guga de Castro e Júnior arruda

Produção de trilha: Júnior Arruda

Poesia citada: "Habitar o Tempo" e "Bifurcados de Habitar o Tempo", de João

Cabral de Melo Neto

Extraído de: http://ciadaarteandancas.wordpress.com/repertorio/o-tempo-da-

delicadezal 


\section{Os Tempos - estréia 02 de agosto}

julho 28, 2008 por andreabardawil

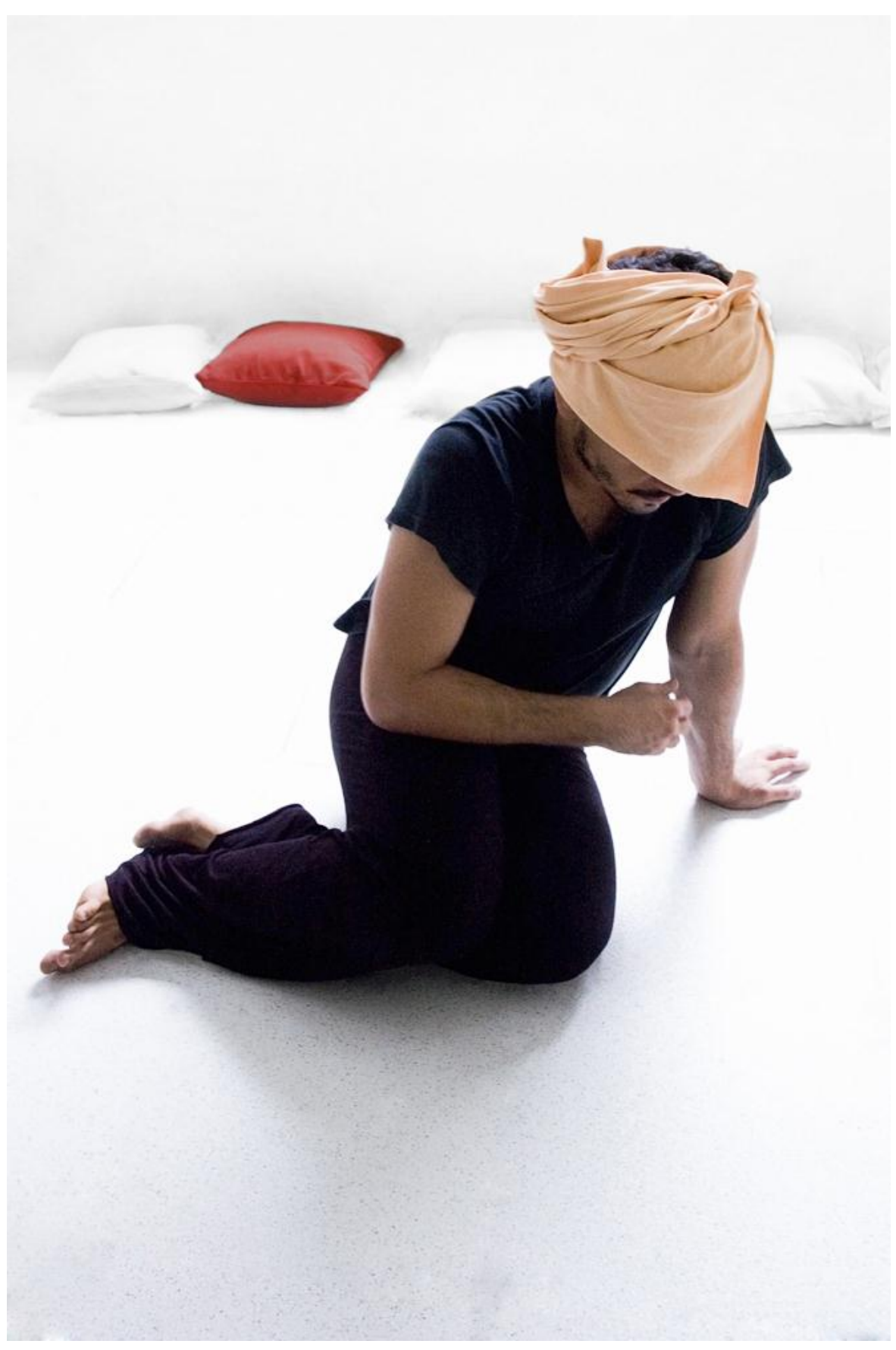

foto: paulo amoreira

De algo que as palavras não dão conta, é no que nos detemos com este trabalho.

Do que se trata viver? Do que se trata estar vivo e passar pela vida?

Não são poucas as vezes em que nos abate a paralisia, diante da inabilidade de lidar com o imponderável. Existem uns que ali permanecem, desistidos, em tempos de um não 
discernimento da vida, dos valores, do que pode valer a pena num regime de economia, distendido ao máximo alcance: pouco movimento, poucos desejos, poucos sonhos, pouco esforço. E existem os que passam, os que simplesmente andam em tempos outros, alheios à aceleração vertiginosa dos dias e das coisas de agora.

Ganhar espaço por dentro exige discrição. Ter coragem exige muita concentração.

Sutil diferença do tempo de economia: mínimo de movimento com o máximo de esforço. A construção de tempos outros: alquimia refinada, a de inverter polaridades internamente, transformando a dor em seiva que nutre.

E eis que me vem uma palavra, que passa a andar comigo, infalivelmente, nos meus passeios silenciosos: resignação...

O que é, onde está?

Passamos então a seguir seus rastros: oriente e ocidente, deserto e caatinga. O que age e o que espera? Para muitos, estado de acomodação passiva do qual se precisa sair. Para outros, tradições religiosas e espiritualistas de um mundo em estado de desagregação, virtude ativa e condição necessária para a conquista da felicidade, estado ao qual se precisa chegar.

Roland Barthes nos lembra, em $\mathrm{O}$ Neutro, o que os japoneses chamam de sabi: "simplicidade, naturalidade, não-conformismo, refinamento, liberdade, familiaridade estranhamente mitigada com desinteresse, banalidade cotidiana requintadamente velada de interioridade transcendental."

De onde se parte e aonde se chega?

Este espetáculo diz respeito a uma forma de estar no mundo, algo que nos interessa observar, pensar e experimentar. Fé, força interior, resignação, capacidade de resistência, qualidade de resistir, neutro, princípio de delicadeza. O que for.

O que importa é que sejamos os que andam. Porque andar nos traz o silêncio, o verdadeiro processo alquímico: a transformação do metal em ouro.

Andréa Bardawil

Concepção, direção e composição coreográfica - Andréa Bardawil

Intérpretes-criadores - Márcio Medeiros, Possidônio Montenegro e Sâmia Bittencourt

http://ciadaarteandancas.wordpress.com/2008/07/28/os-tempos-estreia-02-de-agosto/ 


\section{O Tempo da Paixão ou "O Desejo é um Lago Azul"*}

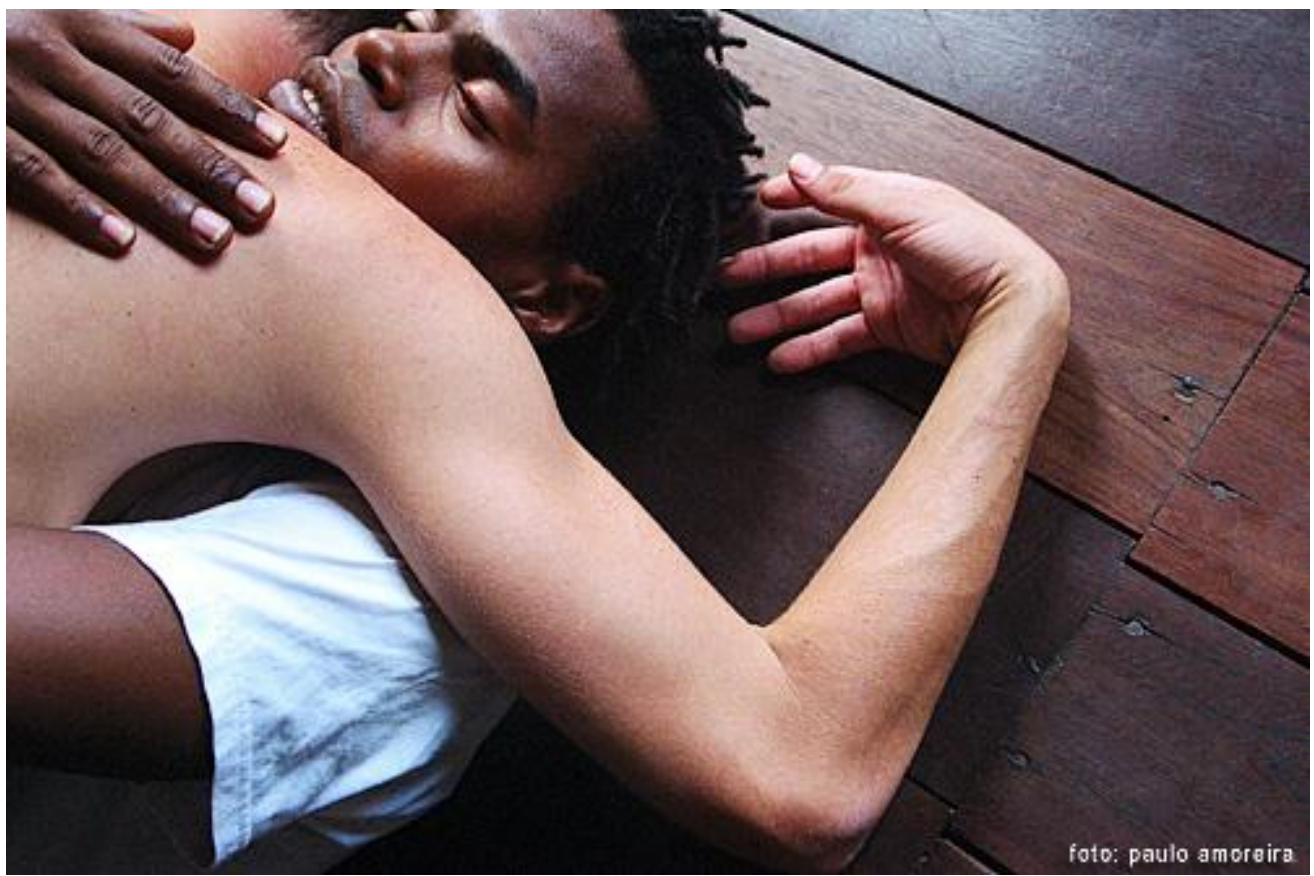

*um trabalho livremente inspirado na obra de Leonilson.

Este trabalho trata sobre o desejo, e um tanto assim de sentimentos/impressões/ coisas que o perpassam e que são perpassados por ele.

A obra de Leonilson, nas palavras de Lisette Lagnado, foi movida "pela compulsão de registrar sua interioridade, a fim de dedicá-las aos objetos do desejo". Para Leonilson, a obra é corpo.

Quando alguém pergunta sobre quem foi Leonilson, quase sempre a primeira resposta é: "um artista plástico cearense que morreu de AIDS". O estigma criado pela doença parece se impor a uma trajetória de vida intensa e preciosa. Quase como se a morte fosse um castigo para quem viveu a vida com tanta intensidade, e a culpa fosse algo do qual não pudéssemos escapar.

O trabalho de Leonilson nos inspira exatamente pela intensidade, aonde o que vai sendo bordado e costurado é a própria vida, o que fica inscrito na própria carne. Como algo tão rudimentar pode trazer em si tanta força? Não é da morte que este trabalho trata, é do desejo, da vida se afirmando a cada dia, apesar de todos os processos de captura de subjetividade a que estamos sujeitos.

As coisas não se reduzem a uma só verdade. Assim como o desejo não se reduz nem a um bem inquestionável nem a um mal necessário. Nem bem nem mal. Nem só falta nem só excesso. Nem só prazer nem só dor. Nem só o que nos faz ficar, nem só o que nos faz partir.

Porque existe a intensidade e intenso não é só o que se move largo, extenso, acelerado. Cabe num travesseiro, o desejo maior do mundo. Um travesseiro bordado, escrito ninguém. Intensa não é a vida que nos cabe: é toda vida que couber em nós. 
Cores, símbolos. Coisas. Tecido, pedra, corpo. Não se trata mais de costurarmos nossa própria carne, imagem já vista e gasta na arte contemporânea, Trata-se de, corpo parado ao vento e algum silêncio, perguntarmos: o que está escrito? Como continuar escrevendo?

Maciez, aspereza. Fluidez. Texturas. (De objetos, imagens, movimentos.) O delicado. O Perigoso. A pele em contato com. Lembrando que, afinal, "o mais profundo é a pele" (Paul Valéry).

Nossa inquietação encontra margem nas palavras de Gilles Deleuze: "De que afetos você é capaz?Experimente, mas é preciso muita prudência para experimentar. Vivemos em um mundo desagradável, onde não apenas as pessoas, mas os poderes estabelecidos têm interesse em nos comunicar afetos tristes.(...) Não é fácil ser um homem livre: fugir da peste, organizar encontros, aumentar a potência de agir, afetar-se de alegria, multiplicar os afetos que exprimem ou envolvem um máximo de afirmação."

E vira dança.

- <!--[endif]-->Este trabalho contou com o apoio Edital de Estímulo à Cultura, da Secult.

Concepção, Direção e Composição Coreográfica - Andréa Bardawil

Intérpretes-criadores - Possidônio Montenegro, Sâmia Bittencourt, Tiago Ribeiro e Carlos Antônio dos Santos

Figurino - Ruth Aragão

Iluminação - Walter Façanha

Concepção Visual - Enrico Rocha e Andréa Bardawil

Fotos - Paulo Amoreira e Bia Pontes

Projeto gráfico - Galciani Neves

Apoio - Secretaria da Cultura do Estado e Alpendre - Casa de Arte, Pesquisa e Produção

http://ciadaarteandancas.wordpress.com/repertorio/o-tempo-da-paixao-ou\%e2\%80\%9co-desejo-e-um-lago-azul\%e2\%80\%9d/ 
ANEXO C - Mapa sensorial criado no processo do espetáculo Os Tempos. 


\section{Os Tempos}

Uma história de encontros. O que um encontro pode provocar?

\begin{tabular}{|c|c|c|c|c|}
\hline $\begin{array}{c}\text { Cena/bloco de } \\
\text { sensação } \\
\\
\text { Dramaturgia - criar } \\
\text { uma linha de } \\
\text { consistência que } \\
\text { estabeleça uma } \\
\text { continuidade que não } \\
\text { remeta a uma } \\
\text { narrativa. }\end{array}$ & $\begin{array}{c}\text { Ambiência } \\
\text { Criar uma ambiência é criar uma } \\
\text { dimensão espaço/temporal. A } \\
\text { instauração de um espaço/tempo. } \\
\text { A ambiência geral do espetáculo } \\
\text { é a co-extensividade entre um } \\
\text { dentro e um fora, cena-público. A } \\
\text { alternância entre um foco de } \\
\text { olhar direto e um indireto inclui o } \\
\text { público na cena, convida, acolhe, } \\
\text { incorpora. } \\
\text { Ambiência } \rightarrow \text { espaço }+ \text { tempo }+ \\
\text { corporeidade }\end{array}$ & $\begin{array}{c}\text { Itinerário sensorial } \\
\text { Comandos e diretrizes para } \\
\text { exploração/improvisação, } \\
\text { qualidades de movimento, } \\
\text { caminhos para constituir } \\
\text { ambiências, descrição de } \\
\text { percursos }\end{array}$ & Trilha sonora & Vídeo-dança \\
\hline $\begin{array}{l}\text { 4. Caminhadas } \\
\text { (somos os que } \\
\text { andam) }\end{array}$ & $\begin{array}{l}\text { Preparação para o } \\
\text { reconhecimento do outro. O outro } \\
\text { ainda é anônimo. O primeiro } \\
\text { encontro é consigo mesmo. }\end{array}$ & $\begin{array}{l}\text { Caminhadas com foco indireto, } \\
\text { alternadas com pausas breves e } \\
\text { gestos sutis. Não há conexão } \\
\text { visual nem contato físico entre } \\
\text { os intérpretes, somente entre eles } \\
\text { e o público. O percurso foi } \\
\text { definido por cada intérprete, } \\
\text { tomando como referência a } \\
\text { escolha de cinco pontos distintos } \\
\text { pela sala, entre os quais se } \\
\text { deslocam, repetindo sempre a } \\
\text { mesma trajetória, indo e vindo. } \\
\text { Se cruzam mas não se }\end{array}$ & Moby piano 1 & $\begin{array}{l}\text { Primeiro, não vemos os } \\
\text { bailarinos em cena, é } \\
\text { como se víssemos } \\
\text { através dos olhos deles, } \\
\text { o que já foi e o porvir. } \\
\text { Aparecem vestígios do } \\
\text { outro, pegadas, sombras, } \\
\text { etc. } \\
\text { Foco nos olhares } \\
\text { Câmeras diferentes } \\
\text { (dispositivos na cabeça) } \\
\text { Talvez caminhadas em } \\
\text { vários lugares. }\end{array}$ \\
\hline
\end{tabular}




\begin{tabular}{|c|c|c|c|c|c|}
\hline & & & encontram. & & \\
\hline & $\begin{array}{l}\text { 19 trio } \\
\text { (encontro } \\
\text { silencioso) }\end{array}$ & $\begin{array}{l}\text { Reconhecimento do outro, } \\
\text { conversa silenciosa, passeio entre } \\
\text { o dentro e o fora (olhar: } \\
\text { alternância entre foco direto e } \\
\text { indireto), espaço co-extensivo, } \\
\text { conexão visual. }\end{array}$ & $\begin{array}{l}\text { Em círculo fechado, os } \\
\text { intérpretes estabelecem o } \\
\text { primeiro contato visual entre si. } \\
\text { Alternância de posições, } \\
\text { marcadas anteriormente. As } \\
\text { posições: encontradas em } \\
\text { improvisação, indicam conexão } \\
\text { entre os três, com ou sem } \\
\text { contato físico. Havendo contato, } \\
\text { no entanto, deve ser sutil. O mais } \\
\text { importante é a passagem de uma } \\
\text { posição a outra: as imagens se } \\
\text { diluem, esvaziando-se e gerando } \\
\text { outra, sem ansiedade. }\end{array}$ & Sino/Silêncio & $\begin{array}{l}\text { Olhadas para a câmera. } \\
\text { Pequenos movimentos } \\
\text { panorâmicos , } \\
\text { sincronizados com os } \\
\text { movimentos do olhar. }\end{array}$ \\
\hline & Solo Márcio & $\begin{array}{l}\text { O quê ou quem se encontra? O } \\
\text { encontro com o ingênuo, com a } \\
\text { simplicidade (que não é } \\
\text { simplória). }\end{array}$ & $\begin{array}{l}\text { Solo construído pelo Márcio. A } \\
\text { partir daí, a proposta foi a } \\
\text { desconstrução de um fluxo } \\
\text { contínuo, a execução do solo } \\
\text { buscando a independência entre } \\
\text { uma ação e outra. Cada } \\
\text { ação/gesto vale por si. }\end{array}$ & $\begin{array}{l}\text { Kathy's Song } \\
\text { (Simon e Garfunkel) }\end{array}$ & $\begin{array}{l}\text { Lugar possível: no curral } \\
\text { (maré seca). }\end{array}$ \\
\hline & $\begin{array}{l}\text { Breve encontro } \\
\text { Márcio/Sâmia } \\
\text { Caminhada } \\
\text { Possi } \\
\text { Observação } \\
\text { Leila }\end{array}$ & $\begin{array}{l}\text { Aproximar, alimentar-se } \\
\text { mutuamente. Passagem. } \\
\text { Caminhar junto é uma forma de } \\
\text { habitar. Habitar é diferente de } \\
\text { invadir. Habitar um mesmo } \\
\text { espaço pode não ser habitar o } \\
\text { mesmo tempo. }\end{array}$ & $\begin{array}{l}\text { Caminhar junto (na mesma } \\
\text { direção e ao mesmo tempo), } \\
\text { porém não necessariamente da } \\
\text { mesma forma. }\end{array}$ & Silêncio & $\begin{array}{l}\text { Talvez: Sâmia conduz o } \\
\text { Márcio boiando. }\end{array}$ \\
\hline & Solo Sâmia & Encontro com a solidão. A & Solo construído pela Sâmia, a & Boi (Márcio e Possi & Talvez: maré seca, beira \\
\hline
\end{tabular}




\begin{tabular}{|c|c|c|c|c|}
\hline & $\begin{array}{l}\text { solidão é uma dimensão do } \\
\text { encontro. Suspensão e } \\
\text { distanciamento. A construção de } \\
\text { uma sabedoria. O cuidado de si e } \\
\text { o cuidado com o outro. Quando o } \\
\text { cuidado se torna excessivo? O } \\
\text { estranhamento entre conforto e } \\
\text { desconforto. }\end{array}$ & $\begin{array}{l}\text { partir da diretriz de priorizar } \\
\text { planos médio e baixo. A partir } \\
\text { daí, a proposta foi trabalhar em } \\
\text { fluxo contido e lento, com sutil } \\
\text { variação de dinâmica no final. }\end{array}$ & cantarolam) & $\begin{array}{l}\text { d'água (impressão dela } \\
\text { flutuando). O elemento } \\
\text { de transição entre os dois } \\
\text { solos é a água. }\end{array}$ \\
\hline $\begin{array}{l}\text { 10. Breve encontro } \\
\text { Possi/Márcio }\end{array}$ & $\begin{array}{l}\text { Aproximação, construção de uma } \\
\text { relação, conexão que se } \\
\text { estabelece sem contato físico. O } \\
\text { espaço de cada um é preservado. } \\
\text { Distanciamento. Desencontro. } \\
\text { Clarice: é que a gente se assusta } \\
\text { com o excesso de doçura do que }\end{array}$ & $\begin{array}{l}\text { Duo composto a partir de } \\
\text { movimentação em fluxo } \\
\text { contínuo e contido, gestos/ações } \\
\text { sutis, sem grandes } \\
\text { deslocamentos e sem contato } \\
\text { físico, um explorando o espaço } \\
\text { indireto do corpo do outro. }\end{array}$ & Silêncio & $\begin{array}{l}\text { Talvez: nas dunas. } \\
\text { Câmera próxima aos } \\
\text { corpos, evidenciando } \\
\text { mais os espaços entre } \\
\text { eles. Movimentos de } \\
\text { câmera acompanhando a } \\
\text { silhueta dos dois corpos. }\end{array}$ \\
\hline
\end{tabular}




\begin{tabular}{|c|c|c|c|c|}
\hline & deve ser isso pela primeira vez.. & & & \\
\hline $\begin{array}{l}\text { 11. Solo } \\
\text { Possi/Márcio } \\
\text { no travesseiro }\end{array}$ & $\begin{array}{l}\text { Encontro com o desassossego. A } \\
\text { proximidade do distante e a } \\
\text { distância do próximo. Uma sina } \\
\text { que se cumpre. }\end{array}$ & & Ruídos rua & Talvez: nas dunas. \\
\hline $\begin{array}{l}\text { 12. Breve encontro } \\
\text { Sâmia/Márcio } \\
\text { Travessia Possi }\end{array}$ & $\begin{array}{l}\text { Do cuidado com o outro. No duo, } \\
\text { a descoberta e o contato com o } \\
\text { outro. A delicadeza possível num } \\
\text { encontro. Intimidade que se } \\
\text { constrói na descoberta do outro. } \\
\text { Na travessia, condição de não- } \\
\text { desistência, algo que está para } \\
\text { além da dor. Não uma condição } \\
\text { de resistência (a algo), mas uma } \\
\text { condição mesma de existência. } \\
\text { Lembrança dos afetos } \\
\text { esquecidos. }\end{array}$ & $\begin{array}{l}\text { Do duo, gestos/ ações } \\
\text { independentes entre si, contato } \\
\text { sutil e delicado. Duo construído } \\
\text { a partir do cuidar do outro. } \\
\text { Pausas em cada postura e entre } \\
\text { elas, um gesto de carinho, } \\
\text { cuidado. }\end{array}$ & Moby piano 2 & \\
\hline $\begin{array}{l}\text { 14. O que se deixa } \\
\text { pra trás (soltura } \\
\text { dos tecidos) }\end{array}$ & & & Silêncio & \\
\hline 15. 20 trio (tecidos) & $\begin{array}{l}\text { O que criamos para nós mesmos } \\
\text { e para os outros. }\end{array}$ & $\begin{array}{l}\text { Os três sentados num círculo no } \\
\text { meio da sala. Os dois tecidos são } \\
\text { manipulados, criando formas e } \\
\text { figuras feitas por cada um. O }\end{array}$ & Silêncio & $\begin{array}{l}\text { Experimentar o } \\
\text { movimento com a } \\
\text { câmera, no lugar do } \\
\text { tecido. }\end{array}$ \\
\hline
\end{tabular}




\begin{tabular}{|c|l|l|l|l|}
\hline & & vermelho estendido no chão. & & \\
\hline 16. 2a manipulação & $\begin{array}{l}\text { Aquele que acredita, ora resiste, } \\
\text { ora se abandona. }\end{array}$ & $\begin{array}{l}\text { Márcio e Sâmia manipulam o } \\
\text { Possi (plano alto) que ora se } \\
\text { deixa manipular, ora manipula. }\end{array}$ & $\begin{array}{l}\text { Benditos/beneditinos } \\
\text { tentar com Bach e } \\
\text { Sivuca) }\end{array}$ & $\begin{array}{l}\text { Talvez: voltar para a } \\
\text { água. }\end{array}$ \\
\hline 17. O abandonar-se & Contato. & $\begin{array}{l}\text { Deslizar, escorrer, passear pelo } \\
\text { outro. }\end{array}$ & $\begin{array}{l}\text { Há tempos e Os } \\
\text { alquimistas estão } \\
\text { chegando }\end{array}$ & \\
\hline
\end{tabular}

O que se chama de cena dentro da dança contemporânea?

Como pensar o público de cinema inserido na cena?

Como problematizar o lugar do olhar?

Sequência de olhares.

\begin{tabular}{|l|l|l|}
\hline \multicolumn{1}{|c|}{$\mathbf{1}^{\mathbf{0}}$ fim de semana } & Durante a semana & \multicolumn{1}{c|}{$\mathbf{2}^{\mathbf{0}}$ fim de semana } \\
\hline $2 . \mathbf{1}^{\mathbf{0}}$ trio (encontro silencioso) & 1. Caminhadas (somos os que andam) & $\mathbf{1 3 . 2}^{\mathbf{0}}$ trio (tecidos) \\
\hline & & \\
\hline & & \\
\hline & & \\
\hline & & \\
\hline & & \\
\hline & & \\
\hline
\end{tabular}


